\title{
22. MINOR-ELEMENT GEOCHEMISTRY OF BASALTS FROM LEG 49, NORTH ATLANTIC OCEAN
}

\author{
John Tarney, Andrew D. Saunders, Stephen D. Weaver, ${ }^{1}$ Nigel C.B. Donnellan, and Graham L. Hendry \\ Department of Geological Sciences, University of Birmingham, Birmingham B15 2TT, England
}

\begin{abstract}
The geochemistry of basalts recovered from seven sites in the North Atlantic is described with particular reference to minor elements. Three sites $(407,408$, and 409$)$ along the same mantle flow line, transverse to the Reykjanes Ridge at about $63^{\circ} \mathrm{N}$, provide information on the composition of basalts erupted over a 34-m.y. interval between 2.3 and $36 \mathrm{~m} . \mathrm{y}$. ago. At Site 410 , at $45^{\circ} \mathrm{N}$, penetration into $10 \mathrm{~m} . \mathrm{y}$.-old crust west of the ridge axis permits comparisons with young basalts dredged from the median valley at $45^{\circ} \mathrm{N}$. Three sites in the FAMOUS area at about $36^{\circ} \mathrm{N}$ provided material from very young ( $\left.1 \mathrm{~m} . \mathrm{y}.\right)$ basaltic crust (Site 411), and material to test the geochemical coherence of basalts of different ages (1.5 and 3.5 m.y.) on either side of a fracture zone (Sites 412 and 413). These sites complement earlier data from dredged and drilled sites (Leg 37) in the FAMOUS area.

At Site 407 , four geochemically distinct basalt units occur, with different normative and rare-earth element (REE) characteristics, and there is a clear correlation with magnetic stratigraphy. Yet there is a remarkable consistency in incompatible element ratios between these units, indicating derivation from an essentially similar mantle source. The basalts from the younger sites, 408 and 409 , show a similar range of normative and REE variation, but incompatible element ratios are identical to those at Site 407 , indicating that basalts at all three sites were produced from a mantle source which was geochemically relatively uniform. Rare-earth differences between the basalts can be interpreted in terms of variations in the degree and depth of partial melting causing HREE $(+Y)$ retention in the source, although there may be some inter-site differences with respect to REE.

A similar picture is presented at $45^{\circ} \mathrm{N}$. Apparently a range of tholeiitic, transitional, and alkalic basalts were being erupted $10 \mathrm{~m}$.y. ago, which have almost identical geochemical characteristics to those recently erupted in the median valley at $45^{\circ} \mathrm{N}$. Incompatible element ratios are markedly different from those recorded at the Reykjanes Ridge. Basalts recovered from the FAMOUS sites are geochemically similar to previous samples recovered from the FAMOUS area, and their incompatible element ratios are similar, but not identical, to those at $45^{\circ} \mathrm{N}$. However, total trace element levels are consistently lower than in $45^{\circ} \mathrm{N}$ basalts, which might imply smaller degrees of partial melting and/or greater depths of magma generation at $45^{\circ} \mathrm{N}$, or higher trace element levels in the mantle source at $45^{\circ} \mathrm{N}$.

Few of the basalts recovered on Leg 49 have the geochemical characteristics of typical "MORB"' (e.g., Nazca Plate, Leg 34). The data strongly support models invoking geochemical inhomogeneity in the source regions of basalts produced at the Mid-Atlantic Ridge. However, the data also introduce an additional time factor into such models and demonstrate the uniformity of the mantle source at a particular ridge sector (over periods in excess of 30 m.y.), while emphasizing the marked differences along the ridge. Mixing models invoking "depleted" and "enriched" mantle sources would seem to be inadequate to account for the observed variations.
\end{abstract} Kenya.

${ }^{1}$ Present address: Department of Geology, University of Nairobi, 


\section{INTRODUCTION}

On Leg 49, basalts were recovered from seven different sites in three different transects across the Mid-Atlantic Ridge, at $63^{\circ} \mathrm{N}$ (Reykjanes Ridge), $45^{\circ} \mathrm{N}$, and $36^{\circ} \mathrm{N}$ (FAMOUS area). The sites range from very young (Site 411 , about 1 m.y.) to almost 36 m.y. (Site 407), and were all selected in areas where considerable data were already available as a result of previous drilling and dredging operations.

That geochemical differences exist in basalts dredged from different sections of the Mid-Atlantic Ridge is now well established (e.g., Schilling, 1975a, b). Because these geochemical differences correlate to some extent with variations in $\mathrm{Sr}$ isotopes (Hart et al., 1973; O'Nions et al., 1976; White et al., 1976); $\mathrm{Pb}$ isotopes (Sun and Jahn, 1975); and $\mathrm{Nd}$ isotopes (O'Nions et al., 1976), there is a general consensus that these differences reflect some sort of geochemical heterogeneity in the mantle source. The nature, degree, and extent of such heterogeneity, however, still remains to be elucidated. Schilling and co-workers (Schilling, 1973, 1975a, 1975b; Schilling and Noe-Nygaard, 1974; Hart et al., 1973; Hermes and Schilling, 1976; White et al., 1976) have proposed models involving mixing of a "depleted" mantle source similar to MORB with a deep "enriched" mantle source feeding oceanic islands and rising up in the form of plumes or blobs in areas such as Iceland and the Azores. In such a model the spectrum of basalt compositions along the Mid-Atlantic Ridge should reflect mixing of the two mantle sources once the effects caused by partial melting and crystal fractionation have been eliminated. Not all geochemists believe, however, that the picture is quite so simple (O'Nions et al., 1976). Langmuir et al. (1978), for instance, have applied mixing equations to the Iceland-Reykjanes Ridge data and have argued that the data are not consistent with either mixing of magmas or simple mixing of an enriched ocean island source with a depleted ocean ridge source. They concluded that there are either two separate mixing trends in the Iceland-Reykjanes Ridge region, or that the basalts have been derived from a multiplicity of sources which have been isolated for hundreds of millions of years.

Leg 49 data contribute an important additional factor into the discussion concerning the nature of mantle heterogeneity in the North Atlantic: namely, time. Sites drilled along mantle flow lines provide information on the constancy (or otherwise) of the compositions of basalts erupted at a particular segment of the axis of the Mid-Atlantic Ridge, which has, of course, a bearing on the scale of homogeneity/heterogeneity. The Reykjanes sites, for instance, situated roughly halfway down the so-called Iceland Plume, might be expected to show a sort of geochemical ebb and flow of basalt compositions, related to variations in the degree of mixing of "enriched" and "depleted" mantle sources with time. The other sites, too, although less distant from the ridge axis, provide information on the geochemical characteristics of basalts in a chronological sense (up to $10 \mathrm{~m} . \mathrm{y}$. at $45^{\circ} \mathrm{N}$, and up to 3.5 m.y. in the FAMOUS area). More importantly, however, they provide additional data on compositional variations along the ridge.
All Leg 49 basalts have been analyzed by the same instrument at the same time, using the same calibration curves and the same correction procedures. Instrumental conditions were arranged to provide the highest precision possible, especially for trace elements. Thus, reported geochemical differences, both within and between sites, are significant.

Our brief for this leg was the analysis of trace elements. However, we have also carried out major element analyses on all the samples supplied, although these may be less accurate than the trace element data (particularly for $\mathrm{Al}$ and $\mathrm{Fe}$ ). In interpreting the data we have confined the discussion to an essentially qualitative assessment of results.

\section{METHODS OF ANALYSIS}

\section{Sample Preparation}

Shipboard samples were supplied already crushed and powdered. Powders judged to be coarser than 240 B.S. mesh were re-ground in a TEMA swing mill, using an agate barrel. Briquettes for analysis were then prepared from 15 grams of rock powder mixed with about 30 drops of a 7 per cent aqueous solution of polyvinyl alcohol (to act as a binder), and then compressed at 15 tons against the polished hardened steel faces of the die. The resulting 46-mm-diameter powder briquettes provide a large surface area for irradiation, thus enhancing sensitivity and precision.

A selection of samples was also analyzed for major elements, using the fusion bead technique to minimize absorption and mineralogical effects. The beads were made by mixing an 0.8 -gram sample with 4.0 grams of 80 percent lithium metaborate-20 per cent lithium tetraborate (Johnson Matthey Spectroflux 100 B) (Bennett and Oliver, 1976), and then fused, with swirling, for 20 minutes in a Pt/Au crucible at $1150^{\circ} \mathrm{C}$ in a vertical tube furnace. Beads were then pressed in aluminum molds using equipment similar to that described by Harvey et al. (1973). The cooled and annealed glass discs were stored in sealed polypropylene bags in a desiccator to prevent atmospheric contamination.

\section{X-Ray Fluorescence Analysis}

The equipment used was a Philips PW1450 automatic spectrometer with a PW1466 sixty-position sample changer. Count data from the spectrometer were processed using a Digital PDP11-03 computer.

Samples for trace-element analysis were measured four times to increase precision and to allow detection of possible "wild" results. Counts were normalized to a reference sample (Araldite MY753 epoxy resin base containing silica and iron oxide filler and spiked with appropriate trace elements) measured as the first sample of a batch of sixty. Instrumental drift is sufficiently low to allow this procedure. Four internal reference samples per batch were used to monitor long-term precision. The results of 20 consecutive instrument loadings for ocean basalt sample BOB-1 are shown in Table 1. Similar procedures were followed for major-element analysis, except that a silicate enamel reference sample was measured every fourth sample. 
TABLE 1

Average Concentration of the Internal Reference Sample

BOB-1 Determined on 20

Consecutive Days

(one sigma deviation)

\begin{tabular}{lrc}
\hline & \multicolumn{1}{c}{ BOB-1 } & BCR-1 \\
\hline $\mathrm{Cr}$ & \multicolumn{1}{c}{$280 \pm 8$} & 16 \\
$\mathrm{Ni}$ & $104.5 \pm 1.8$ & 19 \\
$\mathrm{Zn}$ & $62.6 \pm 1.3$ & 112 \\
$\mathrm{Rb}$ & $4.7 \pm 0.5$ & 45 \\
$\mathrm{Sr}$ & $200.8 \pm 0.9$ & 335 \\
$\mathrm{Y}$ & $28.0 \pm 0.4$ & 36 \\
$\mathrm{Zr}$ & $115.0 \pm 1.2$ & 195 \\
$\mathrm{Nb}$ & $6.2 \pm 1.3$ & 13.7 \\
$\mathrm{Ba}$ & $60.3 \pm 2.4$ & 690 \\
$\mathrm{La}$ & $7.2 \pm 1.1$ & 25 \\
$\mathrm{Ce}$ & $15.0 \pm 1.8$ & 56 \\
$\mathrm{~Pb}$ & $4.4 \pm 1.2$ & 16 \\
$\mathrm{Th}$ & $0.1 \pm 1.0$ & 6 \\
$\mathrm{Ga}$ & $17.4 \pm 0.9$ & 22 \\
\hline
\end{tabular}

\section{Trace-Element Analysis}

To obtain maximum sensitivity and to avoid interferences from the X-ray tube target, the samples were excited using both molybdenum and tungsten anodes. The fluorescent radiation was dispersed using a $\mathrm{LiF}_{220}$ analyzing crystal to achieve maximum peak separation. Instrumental conditions were essentially as detailed in Leake, Hendry, et al. (1969). Wavelengths and choice of tube anode were as follows:

Mo target: $\mathrm{Y}\left(\mathrm{K}_{\alpha}\right), \operatorname{Sr}\left(\mathrm{K}_{\alpha}\right), \mathrm{Rb}\left(\mathrm{K}_{\alpha}\right), \mathrm{Th}\left(\mathrm{L}_{\alpha}\right), \mathrm{Pb}\left(\mathrm{L}_{\beta 1}, 2\right)$, $\mathrm{Ga}\left(\mathrm{K}_{\alpha}\right), \mathrm{Zn}\left(\mathrm{K}_{\alpha}\right), \mathrm{Ba}\left(\mathrm{L}_{\beta 1}, 4\right), \mathrm{W}\left(\mathrm{L}_{\beta 1}\right)$

Corrections were made for the overlap of $\mathrm{RbK}_{\beta}$ on $\mathrm{YK}_{\alpha}$, $\mathrm{CeL} \alpha$ on $\mathrm{BaL}_{\beta}$, and $\mathrm{YK}_{\beta}$ on the $\mathrm{MoK}_{\alpha}$ Compton peak. Background profiles and contamination arising from the $\mathrm{X}$-ray tube target were determined using ultra-pure samples of $\mathrm{SiO}_{2}, \mathrm{Al}_{2} \mathrm{O}_{3}$, and $\mathrm{MgO}$. The minor overlap of the second-order $\mathrm{WL}_{\beta 1}$ escape peak on $\mathrm{Ba}$ was removed by careful setting of the pulse-height window.

W target: $\mathrm{Ni}\left(\mathrm{K}_{\alpha}\right), \mathrm{Cr}\left(\mathrm{K}_{\alpha}\right), \mathrm{Ce}\left(\mathrm{L}_{\beta 1}, 4\right), \mathrm{La}\left(\mathrm{L}_{\alpha}\right), \mathrm{Zr}\left(\mathrm{K}_{\alpha}\right)$, $\mathrm{Nb}\left(\mathrm{K}_{\alpha}\right)$

Corrections were made for the overlap of $\mathrm{SrK}_{\beta 1,3}$ on $\mathrm{ZrK}_{\alpha}$ and the target contamination on $\mathrm{Ni}$ and $\mathrm{Cr}$. Because of the lack of precision inherent in the correction of $\mathrm{CrK}_{\alpha}$ for $\mathrm{VK}_{\beta}$, involving the separation of $\mathrm{VK}_{\alpha}$ from the overlapping $\mathrm{Ti} \mathrm{K}_{\beta}$, the results for chromium are presented uncorrected.

Calibration: Initial calibrations were prepared from a wide range of rock types spiked with the appropriate pure element compound (Leake, Hendry, et al., 1969). These values were then related using either the $\mathrm{WL}_{\beta}$ or $\mathrm{MoK}_{\alpha}$ Compton peaks scattered by the sample to provide correction for total mass absorption for all emission lines shorter than the iron absorption edge (Reynolds, 1967). The slightly inferior method of correction using the W Rayleigh peak was adopted in the automatic analysis procedure to give immediate results. As a check on the values, especially where tungsten was detected in the sample (from tungsten carbide crushing equipment), the concentrations were also calculated using the $\mathrm{MoK}_{\alpha}$ Compton peak.

Cerium and lanthanum calibrations were prepared using basalts previously analyzed by isotope dilution, and these, together with the calibrations for $\mathrm{Ba}$ and $\mathrm{Cr}$, were only for basaltic compositions. No detectable improvement resulted from absorption corrections using tube scatter lines and the count rate on the $\mathrm{FeK}_{\alpha}$ peak designed to determine the absorption coefficient at wavelengths longer than the $\mathrm{Fe}$ absorption edge (Walker, 1973).

Precision and accuracy: The instrumental precision with the techniques used is high, even at relatively low trace-element concentrations. This is illustrated by the results on BOB-1 given in Table 1. Concentrations presented are consistent for all elements. The accuracy can only be judged, however, against international reference samples, which do not cover the range of samples provided by Leg 49 basalts. Data for the basalt BCR-1, analyzed at the same time as the Leg 49 samples, are given in Table 1; further data on a wider range of reference materials is given in Hendry (1975).

\section{Major-Element Analysis}

Major-element analyses were carried out on all the samples, to provide additional data in interpreting the results. Most of the major-element analyses were carried out on powder briquettes. However, potential errors, caused by mineralogical effects, are inherent in the use of powder samples for major-element analysis. To minimize these, a set of representative samples, covering the range of composition in Leg 49 basalts, was selected for analysis using fusion bead discs. These were analyzed in parallel with beads of international standard reference samples, and the determined concentrations were used to establish short-range calibrations for the remaining powder samples. Residual errors are to be expected, in particular for $\mathrm{Al}$ and Fe.

\section{SITE 407}

Site 407 (Figure 1) is on the west flank of the Reykjanes Ridge at $63^{\circ} 56.32^{\prime} \mathrm{N}, 30^{\circ} 34.56^{\prime} \mathrm{W}$; water depth is 2472 meters. Almost 160 meters of basaltic basement was cored, beneath 300 meters of sediment. The site lies on magnetic anomaly 13 (36 to $38 \mathrm{~m} . \mathrm{y}$.), although the intercalated sediments within the upper part of the basement suggest a slightly younger age.

The site is of particular interest for several reasons. First, it lies along the same mantle "flow line" as Sites 408 and 409 , all positioned roughly halfway between the supposed plume-generated basalts of Iceland and the normal mid-ocean ridge basalts (MORB) farther south along the Reykjanes Ridge (Schilling, 1973; Hart et al., 1973). Second, the site lies at the deepest position along the Iceland-Greenland Ridge, and conceivably, accepting for the moment that "plumes" and "mantle blobs" exist (cf. Schilling and Noe-Nygaard, 1974), could represent a period when activity at the Iceland mantle plume/blob was at a minimum. Third, the shipboard paleomagnetism studies revealed a threefold magnetic stratigraphy at Site 407, with distinct downhole variations in inclination and polarity; there was some interest whether this might correlate with an igneous geochemical stratigraphy. Moreover, since these magnetic variations suggest a considerable time range for the eruption of the lavas at Site 407 , it provides an interesting opportunity to test the geochemical coherence of the lavas at one particular site. 


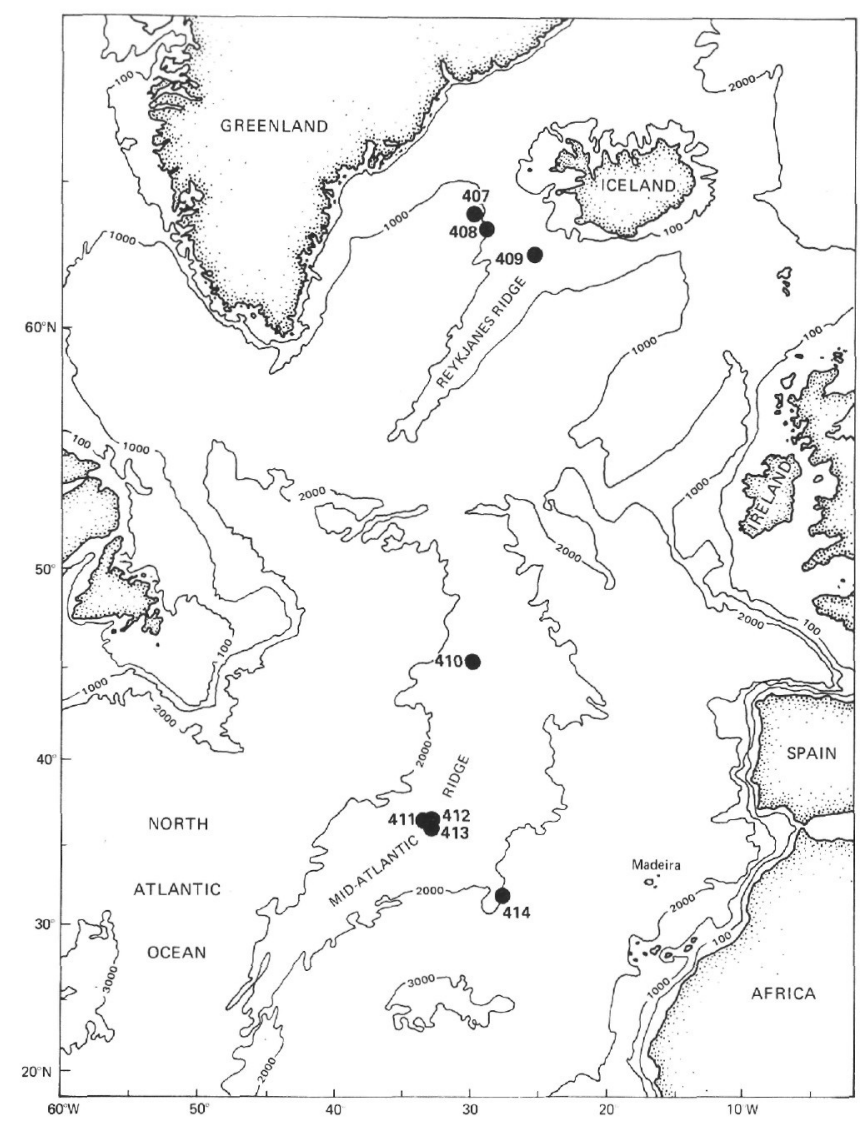

Figure 1. Leg 49 drilling sites at the Reykjanes transect, $45^{\circ} \mathrm{N}$, and the FAMOUS area.
There is little petrographic variation in Site 407 basalts; all the lavas are aphyric or only very slightly $(5 \%)$ porphyritic. Plagioclase and olivine constitute the main phenocrysts, with occasional rare clinopyroxene. Although it is possible to erect a large number of flow units on the basis of variations in petrography and proportion and type of phenocrysts, the geochemical studies reveal that there are four distinct and rather coherent units. The boundaries between three of these units coincide exactly with the changes in magnetic inclination and/or polarity (Figure 2). Shipboard petrographic studies showed a fairly wide range in plagioclase compositions, indicating that some lavas might be quite evolved. Clinopyroxene phenocrysts were restricted to the more evolved lava types.

Almost all the basalts have been affected to some degree by zeolite-facies alteration; the degree of alteration increases in general downhole, and is particularly strong in the lower lava unit below the intercalated sediment. Olivine, titanomagnetite, and interstitial glass are the phases most affected by this low-grade metamorphism; plagioclase phenocrysts are much less susceptible.

\section{Geochemistry}

The geochemical data (Table 2) show a considerable range in composition of Hole 407 lavas. Four distinct chemical units can be defined, and there are breaks in the concentration of most of the major or trace elements at the boundaries of the units (e.g., Figure 2). In exploring the relationship between these geochemical units, it is preferable to use an index of fractionation which is both sensitive to partial melting and/or differentiation and

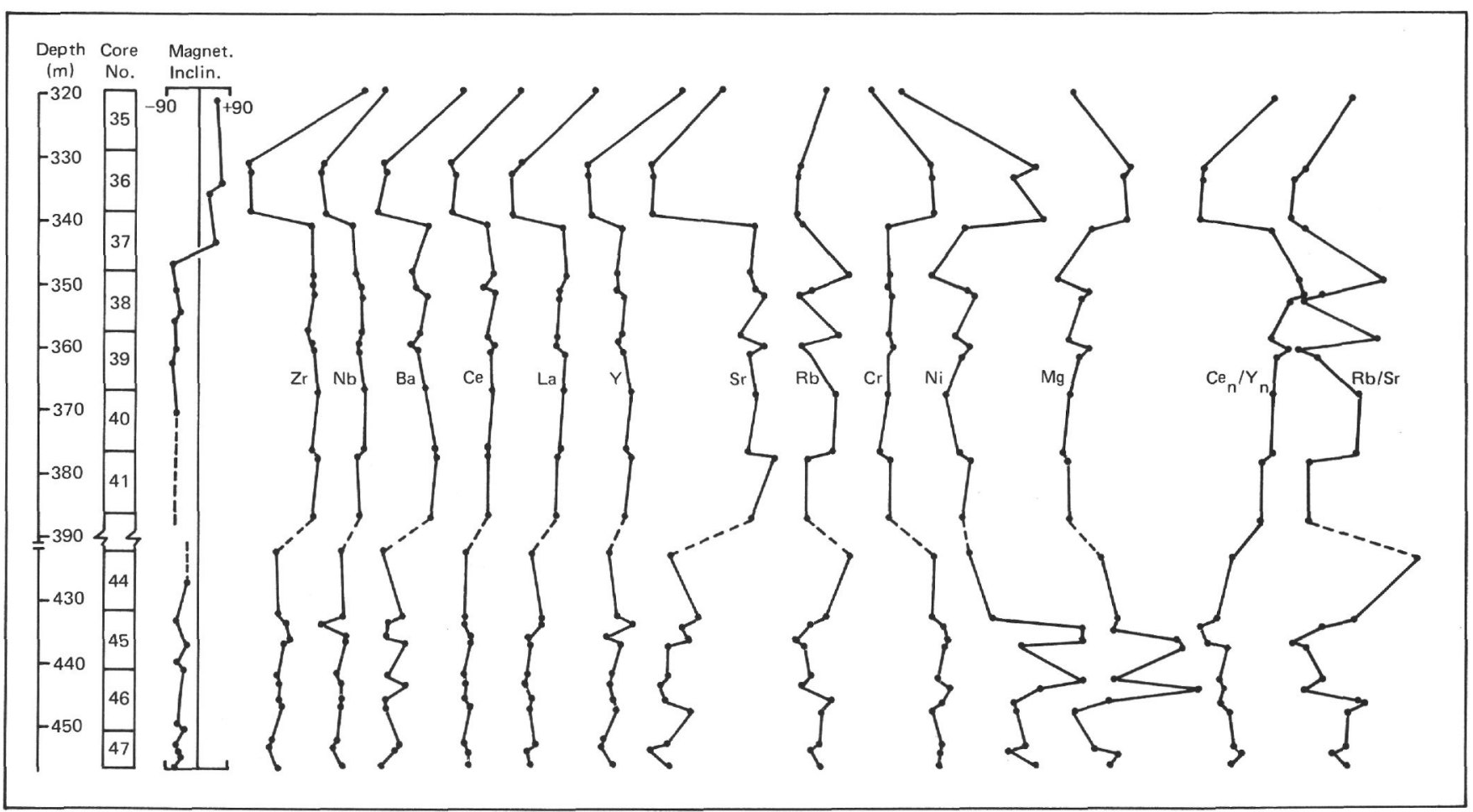

Figure 2. Downhole geochemical variations at Site 407 in relation to magnetic stratigraphy. Plotting scales are linear, but not equal. For clarity in emphasizing sympathetic element variations, they are not shown. 
TABLE 2

Analyses of Basalts From Hole 407, Leg 49

\begin{tabular}{|c|c|c|c|c|c|c|c|c|c|c|c|}
\hline $\begin{array}{c}\text { Core-Section } \\
\text { Interval }(\mathrm{cm}) \\
\text { Piece }\end{array}$ & $\begin{array}{c}35-1 \\
37-39 \\
4 \mathrm{~B}\end{array}$ & $\begin{array}{c}36-2 \\
46-48 \\
2 \mathrm{~A}\end{array}$ & $\begin{array}{c}36-3 \\
74-76 \\
1 \mathrm{C}\end{array}$ & $\begin{array}{c}37-1 \\
74-76 \\
9\end{array}$ & $\begin{array}{c}37-2 \\
74-76 \\
8 \mathrm{~A}\end{array}$ & $\begin{array}{c}38-1 \\
52-54 \\
7\end{array}$ & $\begin{array}{c}38-2 \\
140-142 \\
17\end{array}$ & $\begin{array}{c}38-3 \\
57-59 \\
8\end{array}$ & $\begin{array}{c}39-1 \\
48-51 \\
4\end{array}$ & $\begin{array}{c}39-2 \\
59-61 \\
6\end{array}$ & $\begin{array}{c}39-3 \\
41-43 \\
4\end{array}$ \\
\hline $\mathrm{SiO}_{2}$ & 51.01 & 49.16 & 49.25 & 48.70 & 49.34 & 48.38 & 48.66 & 48.73 & 48.78 & 48.38 & 49.36 \\
\hline $\mathrm{TiO}_{2}$ & 3.57 & 1.45 & 1.50 & 1.44 & 2.73 & 2.88 & 2.80 & 2.87 & 2.78 & 2.87 & 2.78 \\
\hline $\mathrm{Al}_{2} \mathrm{O}_{3}$ & 12.5 & 14.2 & 14.3 & 14.2 & 13.5 & 13.1 & 13.4 & 13.5 & 13.0 & 13.5 & 13.4 \\
\hline $\mathrm{Fe}_{2} \mathrm{O}_{3}$ & 15.11 & 11.96 & 12.15 & 11.30 & 14.75 & 16.56 & 14.72 & 14.44 & 15.96 & 14.10 & 15.23 \\
\hline $\mathrm{MnO}$ & 0.19 & 0.14 & 0.14 & 0.16 & 0.20 & 0.19 & 0.19 & 0.19 & 0.20 & 0.18 & 0.20 \\
\hline $\mathrm{MgO}$ & 5.63 & 9.00 & 8.76 & 8.92 & 6.59 & 4.40 & 6.25 & 6.12 & 5.18 & 6.51 & 5.99 \\
\hline $\mathrm{CaO}$ & 9.21 & 11.86 & 11.62 & 11.85 & 10.91 & 10.38 & 10.89 & 10.91 & 10.85 & 11.01 & 11.05 \\
\hline $\mathrm{Na}_{2} \mathrm{O}$ & 3.11 & 2.01 & 2.10 & 1.93 & 2.44 & 1.98 & 2.40 & 2.51 & 2.06 & 2.58 & 2.50 \\
\hline $\mathrm{K}_{2} \mathrm{O}$ & 0.57 & 0.11 & 0.11 & 0.04 & 0.29 & 0.88 & 0.35 & 0.28 & 0.71 & 0.23 & 0.23 \\
\hline $\mathrm{P}_{2} \mathrm{O}_{5}$ & 0.467 & 0.131 & 0.153 & 0.164 & 0.308 & 0.317 & 0.333 & 0.327 & 0.263 & 0.343 & 0.288 \\
\hline Total & 101.4 & 100.0 & 100.1 & 98.7 & 101.0 & 99.0 & 100.0 & 99.9 & 99.7 & 99.7 & 101.1 \\
\hline
\end{tabular}

\section{Trace elements in ppm}

\begin{tabular}{|c|c|c|c|c|c|c|c|c|c|c|c|}
\hline $\mathrm{Ni}$ & 19 & 99 & 84 & 106 & 57 & 36 & 61 & 64 & 52 & 61 & 57 \\
\hline $\mathrm{Cr}$ & 52 & 228 & 233 & 244 & 99 & 100 & 102 & 104 & 99 & 107 & 101 \\
\hline $\mathrm{Ga}$ & 23 & 20 & 19 & 19 & 23 & 22 & 2 & 22 & 21 & 22 & 23 \\
\hline $\mathrm{Rb}$ & 10 & 2 & 1 & $<1$ & 3 & 17 & 6 & 2 & 15 & 2 & 5 \\
\hline $\mathrm{Sr}$ & 201 & 159 & 160 & 159 & 225 & 222 & 226 & 231 & 215 & 229 & 222 \\
\hline$Y$ & 53 & 24 & 24 & 26 & 35 & 33 & 34 & 36 & 35 & 34 & 36 \\
\hline $\mathrm{Zr}$ & 263 & 80 & 83 & 87 & 182 & 180 & 183 & 183 & 176 & 181 & 185 \\
\hline $\mathrm{Nb}$ & 29 & 10 & 9 & 11 & 19 & 20 & 22 & 22 & 22 & 21 & 21 \\
\hline $\mathrm{Ba}$ & 172 & 45 & 49 & 38 & 119 & 92 & 101 & 113 & 104 & 93 & 101 \\
\hline $\mathrm{La}$ & 23 & 7 & 7 & 5 & 17 & 18 & 19 & 18 & 15 & 18 & 16 \\
\hline $\mathrm{Ce}$ & 60 & 16 & 16 & 17 & 39 & 43 & 45 & 45 & 39 & 42 & 42 \\
\hline $\mathrm{Pb}$ & 5 & 3 & 5 & 2 & 4 & 5 & 3 & 4 & 4 & 3 & 5 \\
\hline Th & 3 & -1 & 1 & -1 & 1 & 1 & 2 & -1 & 3 & 1 & 2 \\
\hline $\mathrm{Zn}$ & 130 & 78 & 81 & 83 & 98 & 108 & 121 & 107 & 106 & 108 & 116 \\
\hline
\end{tabular}

Selected element ratios

\begin{tabular}{|c|c|c|c|c|c|c|c|c|c|c|c|}
\hline \\
\hline $\mathrm{K} / \mathrm{Rb}$ & 473.2 & 456.6 & 913.1 & - & 802.4 & 429.7 & 484.2 & 1162.1 & 392.9 & 954.6 & 531.3 \\
\hline $\mathrm{Rb} / \mathrm{Sr}$ & 0.050 & 0.013 & 0.006 & - & 0.013 & 0.077 & 0.027 & 0.009 & 0.070 & 0.009 & 0.023 \\
\hline $\mathrm{Ba} / \mathrm{Sr}$ & 0.86 & 0.28 & 0.31 & 0.24 & 0.53 & 0.41 & 0.45 & 0.49 & 0.48 & 0.41 & 0.45 \\
\hline $\mathrm{Zr} / \mathrm{Nb}$ & 9.1 & 8.0 & 9.2 & 7.9 & 9.6 & 9.0 & 8.3 & 8.3 & 8.0 & 8.6 & 8.8 \\
\hline $\mathrm{Zr} / \mathrm{Ce}$ & 4.4 & 5.0 & 5.2 & 5.1 & 4.7 & 4.2 & 4.1 & 4.1 & 4.5 & 4.3 & 4.4 \\
\hline $\mathrm{Zr} / \mathrm{Y}$ & 5.0 & 3.3 & 3.5 & 3.4 & 5.2 & 5.5 & 5.4 & 5.1 & 5.0 & 5.3 & 5.1 \\
\hline $\mathrm{Ce}_{\mathrm{N}} / \mathrm{Y}_{\mathrm{N}}$ & 2.78 & 1.63 & 1.64 & 1.60 & 2.72 & 3.18 & 3.25 & 3.05 & 2.72 & 3.02 & 2.85 \\
\hline $\mathrm{tFe} / \mathrm{Mg}$ & 3.1 & 1.5 & 1.6 & 1.5 & 2.6 & 4.4 & 2.7 & 2.7 & 3.6 & 2.5 & 2.9 \\
\hline \multicolumn{12}{|c|}{ C.I.P.W. Norm } \\
\hline Q & 2.3 & 0.0 & 0.0 & 0.0 & 0.3 & 2.9 & 0.3 & 0.4 & 2.0 & 0.0 & 0.5 \\
\hline Or & 3.4 & 0.7 & 0.7 & 0.2 & 1.7 & 5.3 & 2.1 & 1.7 & 4.3 & 1.4 & 1.9 \\
\hline $\mathrm{Ab}$ & 26.3 & 17.2 & 17.9 & 16.7 & 20.7 & 17.2 & 20.6 & 21.5 & 17.7 & 22.1 & 21.2 \\
\hline An & 18.4 & 29.7 & 29.5 & 30.6 & 25.0 & 24.7 & 25.1 & 251. & 24.4 & 25.0 & 24.4 \\
\hline $\mathrm{Ne}$ & 0.0 & 0.0 & 0.0 & 0.0 & 0.0 & 0.0 & 0.0 & 0.0 & 0.0 & 0.0 & 0.0 \\
\hline $\mathrm{Di}$ & 20.1 & 23.5 & 22.7 & 23.2 & 22.6 & 21.9 & 22.7 & 22.9 & 23.9 & 23.3 & 23.9 \\
\hline Hy & 18.9 & 19.2 & 19.8 & 21.5 & 21.1 & 18.6 & 20.3 & 19.5 & 18.8 & 17.7 & 19.5 \\
\hline $\mathrm{Ol}$ & 0.0 & 4.5 & 4.0 & 2.5 & 0.0 & 0.0 & 0.0 & 0.0 & 0.0 & 1.6 & 0.0 \\
\hline Mt & 2.6 & 2.1 & 2.1 & 2.0 & 2.6 & 3.0 & 2.6 & 2.5 & 2.8 & 2.5 & 2.7 \\
\hline Il & 6.8 & 2.8 & 2.9 & 2.8 & 5.1 & 5.6 & 5.4 & 5.5 & 5.4 & 5.5 & 5.3 \\
\hline Ap & 1.1 & 0.3 & 0.4 & 0.4 & 0.7 & 0.8 & 0.8 & 0.8 & 0.6 & 0.8 & 0.7 \\
\hline
\end{tabular}

insensitive to alteration and low-grade metamorphism. Zirconium is ideal in this respect (Tarney et al., 1977), since it can be determined with high precision by XRF techniques and behaves in an almost ideally incompatible fashion in tholeiitic liquid systems. An alternative major-element parameter such as $\mathrm{Fe} / \mathrm{Mg}$ ratio is more susceptible to alteration processes, and to factors such as varying $\mathrm{pH}_{2} \mathrm{O}$ and $\mathrm{pO}_{2}$ attending partial melting. Moreover, because of absorption problems, $\mathrm{Fe}$ and $\mathrm{Mg}$ are determined with much less accuracy than Zr by XRF techniques.

Normative mineral proportions can be used to indicate the petrological character of the lavas. Because ferrous/ferric ratios were not determined, and because in any case ferrous/ferric ratios are highly dependent on the degree of 
TABLE 2-Continued

\begin{tabular}{|c|c|c|c|c|c|c|c|c|c|c|c|}
\hline $\begin{array}{c}\text { Core-Section } \\
\text { Interval }(\mathrm{cm}) \\
\text { Piece }\end{array}$ & $\begin{array}{c}40-1 \\
57-61 \\
7\end{array}$ & $\begin{array}{c}41-1 \\
16-20 \\
3\end{array}$ & $\begin{array}{c}41-1 \\
95 \\
12\end{array}$ & $\begin{array}{c}42-1 \\
87-89 \\
-\end{array}$ & $\begin{array}{c}44-1 \\
17-19 \\
-\end{array}$ & $\begin{array}{c}45-1 \\
69-71 \\
-\end{array}$ & $\begin{array}{c}45-2 \\
40-41 \\
-\end{array}$ & $\begin{array}{c}45-3 \\
122-124 \\
-\end{array}$ & $\begin{array}{c}45-4 \\
53-55 \\
-\end{array}$ & $\begin{array}{c}46-1 \\
63-65 \\
5\end{array}$ & $\begin{array}{c}46-2 \\
59-61 \\
1 \mathrm{~B}\end{array}$ \\
\hline $\mathrm{SiO}_{2}$ & 48.67 & 48.84 & 49.03 & 49.07 & 47.47 & 47.34 & 47.12 & 48.06 & 49.17 & 48.06 & 48.85 \\
\hline $\mathrm{TiO}_{2}$ & 2.72 & 2.75 & 2.78 & 2.79 & 1.99 & 2.02 & 2.13 & 2.21 & 2.05 & 1.95 & 1.99 \\
\hline $\mathrm{Al}_{2} \mathrm{O}_{3}$ & 19.9 & 13.1 & 13.2 & 13.2 & 12.88 & 12.5 & 13.3 & 13.2 & 13.0 & 13.5 & 13.1 \\
\hline $\mathrm{Fe}_{2} \mathrm{O}_{3}$ & 14.79 & 15.55 & 14.10 & 15.12 & 14.66 & 15.41 & 11.89 & 12.34 & 12.18 & 12.62 & 12.52 \\
\hline $\mathrm{MnO}$ & 0.21 & 0.27 & 0.21 & 0.21 & 0.16 & 0.15 & 0.16 & 0.14 & 0.14 & 0.18 & 0.14 \\
\hline $\mathrm{MgO}$ & 5.25 & 4.93 & 6.15 & 6.41 & 7.37 & 8.42 & 8.22 & 10.33 & 10.53 & 8.27 & 11.53 \\
\hline $\mathrm{CaO}$ & 10.88 & 11.10 & 11.01 & 11.01 & 11.40 & 10.80 & 11.48 & 10.77 & 10.28 & 11.46 & 10.19 \\
\hline $\mathrm{Na}_{2} \mathrm{O}$ & 2.06 & 2.08 & 2.37 & 2.36 & 1.83 & 1.98 & 2.17 & 2.12 & 2.24 & 2.20 & 2.12 \\
\hline $\mathrm{K}_{2} \mathrm{O}$ & 0.62 & 0.64 & 0.30 & 0.30 & 0.90 & 0.56 & 0.65 & 0.18 & 0.25 & 0.45 & 0.25 \\
\hline $\mathrm{P}_{2} \mathrm{O}_{5}$ & 0.231 & 0.236 & 0.237 & 0.260 & 0.246 & 0.248 & 0.310 & 0.276 & 0.243 & 0.235 & 0.231 \\
\hline Total & 98.3 & 99.4 & 99.4 & 100.7 & 98.8 & 99.4 & 97.4 & 99.7 & 100.1 & 98.9 & 100.9 \\
\hline \multicolumn{12}{|c|}{ Trace elements in ppm } \\
\hline $\mathrm{Ni}$ & 46 & 54 & 61 & 57 & 62 & 76 & 133 & 132 & 97 & 133 & 105 \\
\hline $\mathrm{Cr}$ & 99 & 59 & 105 & 100 & 251 & 248 & 278 & 291 & 279 & 260 & 296 \\
\hline $\mathrm{Ga}$ & 20 & 21 & 21 & 22 & 19 & 19 & 21 & 22 & 21 & 17 & 20 \\
\hline $\mathrm{Rb}$ & 13 & 12 & 4 & 4 & 18 & 10 & 5 & 1 & 3 & 5 & 3 \\
\hline $\mathrm{Sr}$ & 226 & 220 & 236 & 222 & 171 & 190 & 178 & 183 & 170 & 169 & 165 \\
\hline $\mathrm{Y}$ & 38 & 36 & 38 & 36 & 31 & 34 & 39 & 41 & 35 & 32 & 32 \\
\hline $\mathrm{Zr}$ & 191 & 181 & 188 & 185 & 126 & 131 & 143 & 151 & 142 & 130 & 133 \\
\hline $\mathrm{Nb}$ & 23 & 23 & 21 & 22 & 16 & 17 & 20 & 18 & 17 & 15 & 16 \\
\hline $\mathrm{Ba}$ & 112 & 129 & 129 & 123 & 48 & 79 & 52 & 53 & 81 & 53 & 86 \\
\hline $\mathrm{La}$ & 16 & 17 & 17 & 17 & 13 & 14 & 14 & 11 & 10 & 12 & 12 \\
\hline $\mathrm{Ce}$ & 43 & 40 & 40 & 39 & 27 & 26 & 26 & 29 & 29 & 25 & 26 \\
\hline $\mathrm{Pb}$ & 7 & 5 & 3 & 4 & 2 & 3 & 3 & 4 & 3 & 4 & 2 \\
\hline Th & 4 & -1 & 2 & 1 & -1 & -1 & -1 & 2 & 1 & 1 & -1 \\
\hline $\mathrm{Zn}$ & 122 & 116 & 121 & 109 & 90 & 89 & 99 & 107 & 101 & 92 & 94 \\
\hline \multicolumn{12}{|c|}{ Selected element ratios } \\
\hline $\mathrm{K} / \mathrm{Rb}$ & 395.9 & 442.7 & 622.6 & 622.6 & 415.1 & 464.9 & 1079.1 & 1494.2 & 691.8 & 747.1 & 691.8 \\
\hline $\mathrm{Rb} / \mathrm{Sr}$ & 0.058 & 0.055 & 0.017 & 0.018 & 0.105 & 0.053 & 0.028 & 0.005 & 0.018 & 0.030 & 0.018 \\
\hline $\mathrm{Ba} / \mathrm{Sr}$ & 0.50 & 0.59 & 0.55 & 0.55 & 0.28 & 0.42 & 0.29 & 0.29 & 0.48 & 0.31 & 0.52 \\
\hline $\mathrm{Zr} / \mathrm{Nb}$ & 8.3 & 7.9 & 9.0 & 8.4 & 7.9 & 7.7 & 7.2 & 8.4 & 8.4 & 8.7 & 8.3 \\
\hline $\mathrm{Zr} / \mathrm{Ce}$ & 4.4 & 4.5 & 4.7 & 4.7 & 4.7 & 5.0 & 5.5 & 5.2 & 4.9 & 5.21 & 5.1 \\
\hline $\mathrm{Zr} / \mathrm{Y}$ & 5.0 & 5.0 & 5.0 & 5.1 & 4.1 & 3.9 & 3.7 & 3.7 & 4.1 & 4.1 & 4.2 \\
\hline $\mathrm{Ce}_{\mathrm{N}} / \mathrm{Y}_{\mathrm{N}}$ & 2.77 & 2.72 & 257 & 2.65 & 2.13 & 1.87 & 1.63 & 1.74 & 2.02 & 1.91 & 1.99 \\
\hline $\mathrm{tFe} / \mathrm{Mg}$ & 3.3 & 3.6 & 2.6 & 2.7 & 2.3 & 2.1 & 1.7 & 1.4 & 1.3 & 1.8 & 1.2 \\
\hline \multicolumn{12}{|l|}{ C.I.P.W. Norm } \\
\hline $\mathrm{Q}$ & 2.8 & 2.4 & 1.4 & 0.5 & 0.0 & 0.0 & 0.0 & 0.0 & 0.0 & 0.0 & 0.0 \\
\hline Or & 3.8 & 3.9 & 1.8 & 1.8 & 5.5 & 3.4 & 4.0 & 1.1 & 1.5 & 2.7 & 1.5 \\
\hline $\mathrm{Ab}$ & 18.0 & 17.9 & 20.4 & 20.1 & 15.9 & 17.1 & 19.0 & 18.2 & 19.1 & 19.0 & 18.0 \\
\hline An & 24.7 & 24.8 & 25.0 & 24.6 & 24.7 & 24.0 & 25.4 & 26.4 & 24.9 & 26.1 & 25.4 \\
\hline $\mathrm{Ne}$ & 0.0 & 0.0 & 0.0 & 0.0 & 0.0 & 0.0 & 0.0 & 0.0 & 0.0 & 0.0 & 0.0 \\
\hline Di & 24.5 & 24.9 & 24.1 & 23.7 & 26.1 & 23.9 & 25.7 & 21.1 & 20.2 & 24.9 & 19.2 \\
\hline Hy & 17.7 & 17.4 & 18.8 & 20.6 & 14.0 & 15.2 & 9.5 & 17.5 & 20.5 & 13.0 & 18.7 \\
\hline $\mathrm{Ol}$ & 0.0 & 0.0 & 0.0 & 0.0 & 6.7 & 9.2 & 9.1 & 8.6 & 7.0 & 7.6 & 10.7 \\
\hline $\mathrm{Mt}$ & 2.6 & 2.8 & 2.5 & 2.6 & 2.6 & 2.7 & 2.1 & 2.2 & 2.1 & 2.2 & 2.2 \\
\hline Il & 5.3 & 5.2 & 5.4 & 5.3 & 3.9 & 3.9 & 4.2 & 4.2 & 3.9 & 3.8 & 3.8 \\
\hline Ap & 0.6 & 0.6 & 0.6 & 0.6 & 0.6 & 0.6 & 0.8 & 0.7 & 0.6 & 0.6 & 0.6 \\
\hline
\end{tabular}

alteration and at the same time have an important effect on the CIPW norm calculation, a $\mathrm{Fe}^{3+} / \mathrm{Fe}^{3+}+\mathrm{Fe}^{2+}$ ratio of 0.15 was assumed. The normative compositions of the basalts are presented in Figure 3. Unit I is mildly quartz-normative, Unit II basalts are distinctly olivine-normative, Unit III basalts are very slightly quartz-normative, whereas Unit IV basalts are again distinctly olivine-normative. The scatter in Unit IV samples is probably real, and reflects alteration processes. All Site 407 basalts have appreciable normative hypersthene and none shows alkaline characteristics. There is rather more variability in the normative composition of Unit IV basalts, perhaps because of the greater degree of alteration shown by these basalts. There are no consistent downhole variations within each unit that might suggest a differentiated sequence. In terms of $\mathrm{Mg} / \mathrm{Fe}$ ratio and incompatible 
TABLE 2-Continued

\begin{tabular}{|c|c|c|c|c|c|}
\hline $\begin{array}{c}\text { Core-Section } \\
\text { Interval }(\mathrm{cm}) \\
\text { Piece }\end{array}$ & $\begin{array}{c}46-3 \\
66-68 \\
4 \mathrm{~A}\end{array}$ & $\begin{array}{c}46-4 \\
68-72 \\
4\end{array}$ & $\begin{array}{c}47-2 \\
12-15 \\
1 \mathrm{~B}\end{array}$ & $\begin{array}{c}47-2 \\
90-95 \\
2\end{array}$ & $\begin{array}{c}47-4 \\
41-47 \\
1 \mathrm{~B}\end{array}$ \\
\hline $\mathrm{SiO}_{2}$ & 47.91 & 45.37 & 46.37 & 47.81 & 48.41 \\
\hline $\mathrm{TiO}_{2}$ & 1.90 & 1.98 & 1.85 & 1.73 & 1.90 \\
\hline $\mathrm{Al}_{2} \mathrm{O}_{3}$ & 13.1 & 13.2 & 13.0 & 13.3 & 13.4 \\
\hline $\mathrm{Fe}_{2} \mathrm{O}_{3}$ & 13.93 & 14.73 & 15.20 & 12.89 & 13.64 \\
\hline $\mathrm{MnO}$ & 0.19 & 0.18 & 0.31 & 0.20 & 0.18 \\
\hline $\mathrm{MgO}$ & 7.71 & 5.73 & 6.97 & 8.39 & 7.99 \\
\hline $\mathrm{CaO}$ & 11.78 & 12.76 & 12.04 & 11.63 & 11.82 \\
\hline $\mathrm{Na}_{2} \mathrm{O}$ & 1.91 & 1.73 & 1.89 & 2.16 & 2.05 \\
\hline $\mathrm{K}_{2} \mathrm{O}$ & 0.53 & 0.73 & 0.48 & 0.63 & 0.42 \\
\hline $\mathrm{P}_{2} \mathrm{O}_{5}$ & 0.205 & 0.259 & 0.218 & 0.223 & 0.214 \\
\hline Total & 99.2 & 96.6 & 98.4 & 98.9 & 100.0 \\
\hline \multicolumn{6}{|c|}{ Trace elements in ppm } \\
\hline $\mathrm{Ni}$ & 90 & 91 & 97 & 87 & 103 \\
\hline $\mathrm{Cr}$ & 272 & 245 & 274 & 2276 & 265 \\
\hline $\mathrm{Ga}$ & 19 & 22 & 18 & 19 & 19 \\
\hline $\mathrm{Rb}$ & 11 & 9 & 8 & 6 & 8 \\
\hline $\mathrm{Sr}$ & 169 & 185 & 168 & 158 & 168 \\
\hline $\mathrm{Y}$ & 33 & 34 & 29 & 29 & 32 \\
\hline $\mathrm{Zr}$ & 132 & 136 & 119 & 118 & 131 \\
\hline $\mathrm{Nb}$ & 16 & 16 & 15 & 24 & 16 \\
\hline $\mathrm{Ba}$ & 51 & 54 & 75 & 70 & 47 \\
\hline $\mathrm{La}$ & 12 & 11 & 11 & 10 & 10 \\
\hline $\mathrm{Ce}$ & 26 & 29 & 26 & 27 & 28 \\
\hline $\mathrm{Pb}$ & 2 & 3 & 3 & 5 & 4 \\
\hline Th & -1 & -1 & -1 & 1 & -1 \\
\hline $\mathrm{Zn}$ & 92 & 8 & 85 & 91 & 92 \\
\hline \multicolumn{6}{|c|}{ Selected element ratios } \\
\hline $\mathrm{K} / \mathrm{Rb}$ & 400.0 & 673.3 & 498.1 & 871.6 & 435.8 \\
\hline $\mathrm{Rb} / \mathrm{Sr}$ & 0.065 & 0.049 & 0.048 & 0.038 & 0.048 \\
\hline $\mathrm{Ba} / \mathrm{Sr}$ & 0.030 & 0.29 & 0.45 & 0.44 & 0.28 \\
\hline $\mathrm{Zr} / \mathrm{Nb}$ & 8.2 & 8.4 & 7.9 & 8.4 & 8.2 \\
\hline $\mathrm{Zr} / \mathrm{Ce}$ & 5.1 & 4.7 & 4.6 & 4.4 & 4.7 \\
\hline $\mathrm{Zr} / \mathrm{Y}$ & 4.0 & 4.0 & 4.1 & 4.1 & 4.1 \\
\hline $\mathrm{Ce}_{\mathrm{N}} / \mathrm{Y}_{\mathrm{N}}$ & 1.93 & 2.08 & 2.19 & 2.28 & 2.14 \\
\hline $\mathrm{tFe} / \mathrm{Mg}$ & 2.1 & 3.0 & 2.5 & 1.8 & 2.0 \\
\hline \multicolumn{6}{|l|}{ C.I.P.W. Norm } \\
\hline Q & 0.0 & 0.0 & 0.0 & 0.0 & 0.0 \\
\hline Or & 3.2 & 4.5 & 2.9 & 3.8 & 2.5 \\
\hline $\mathrm{Ab}$ & 16.5 & 15.3 & 16.5 & 18.7 & 17.5 \\
\hline An & 26.1 & 27.3 & 26.4 & 25.2 & 26.3 \\
\hline $\mathrm{Ne}$ & 0.0 & 0.0 & 0.0 & 0.0 & 0.0 \\
\hline $\mathrm{Di}$ & 26.5 & 31.1 & 27.9 & 26.4 & 26.0 \\
\hline $\mathrm{Hy}$ & 15.6 & 6.3 & 9.9 & 8.6 & 15.1 \\
\hline $\mathrm{Ol}$ & 5.4 & 8.1 & 9.4 & 11.0 & 6.0 \\
\hline Mt & 2.5 & 2.7 & 2.7 & 2.3 & 2.4 \\
\hline Il & 3.7 & 3.9 & 3.6 & 3.4 & 3.6 \\
\hline $\mathrm{Ap}$ & 0.5 & 0.6 & 0.5 & 0.5 & 0.5 \\
\hline
\end{tabular}

trace-element abundance levels, Unit II basalts are the most primitive. They (or a similar magma batch) could conceivably have given rise to the quartz-normative basalts of Units I and III by crystal differentiation. It is unlikely, however, that they could be parental to the slightly more evolved olivine basalts of Unit IV, since these have a consistently higher normative olivine content. In practice, the chronological relationships between the four units, indicated by the magnetic stratigraphy, rule out any direct connection between Units II and IV or II and III. We need, therefore, only to consider whether these magma batches could be related by the same processes of crystal fractionation, partial melting, etc., irrespective of time. Because of the wide range of fractionation exhibited at Site 407, perhaps greater than at any other DSDP site, we reproduce in Figures 4 through 18 a visual summary of 


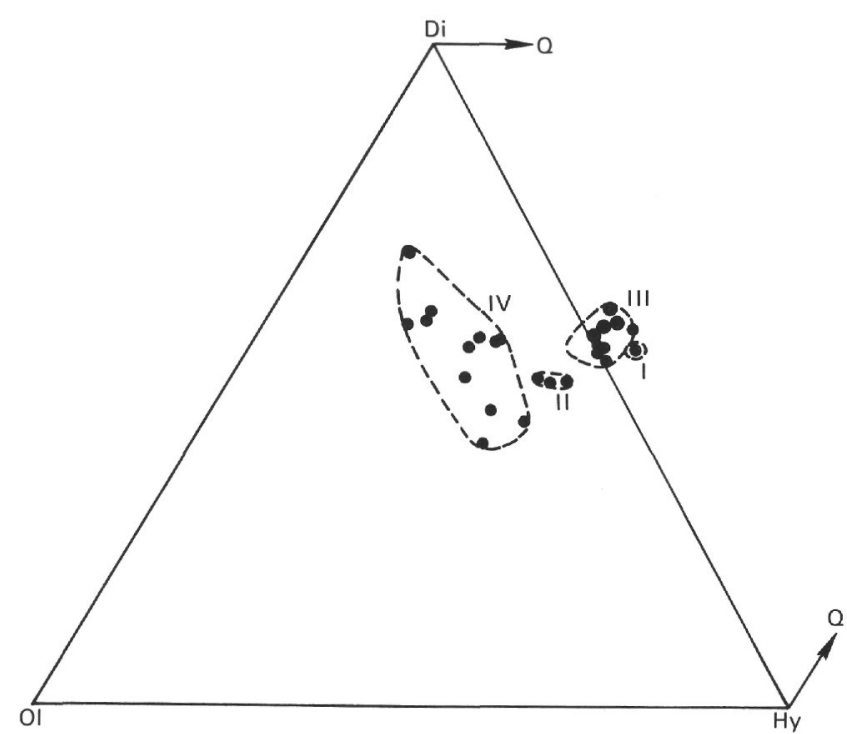

Figure 3. Normative compositions of Site 407 basalts, plotted in the system Olivine-Diopside-Hypersthene (-QuartzNepheline). Numerals indicate geochemical units.

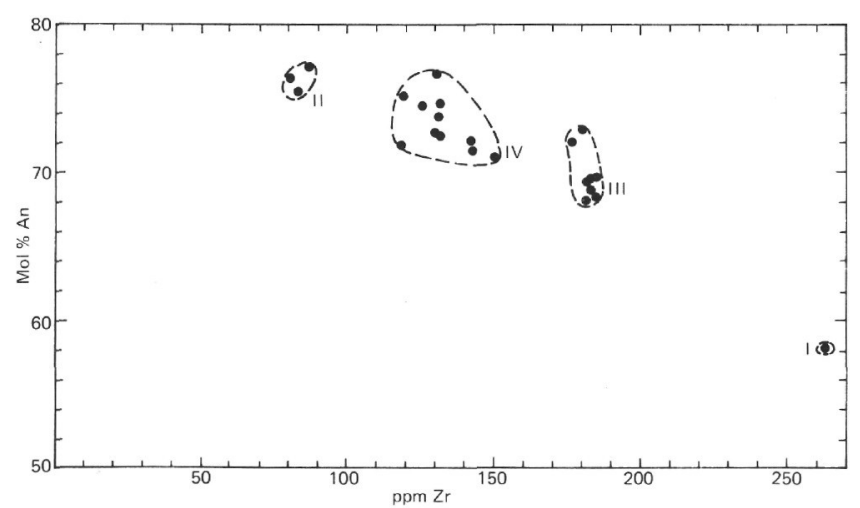

Figure 4. Normative plagioclase compositions for Site 407 basalts plotted against zirconium as a fractionation index. Numerals indicate geochemical units in downhole order.

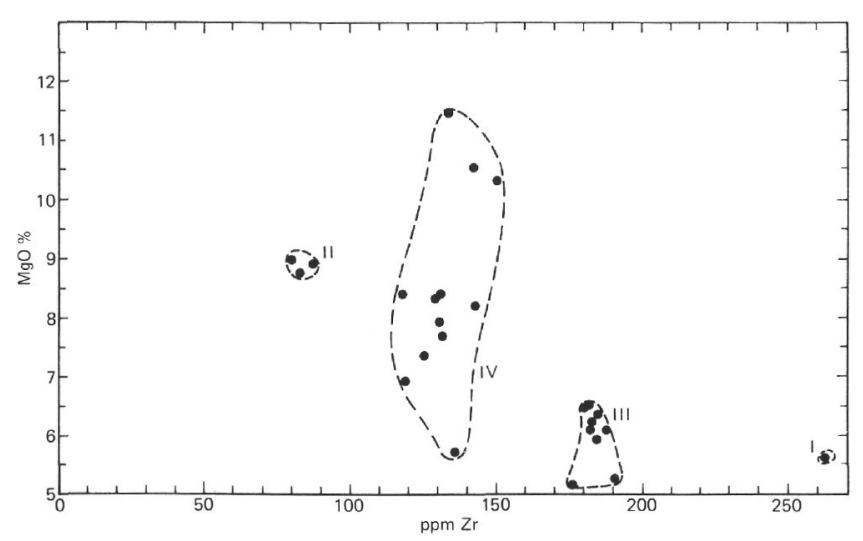

Figure 5. $\mathrm{MgO}$ versus $\mathrm{Zr}$ for Site 407 basalts. The increased dispersion in the lower units may be a result of alteration.

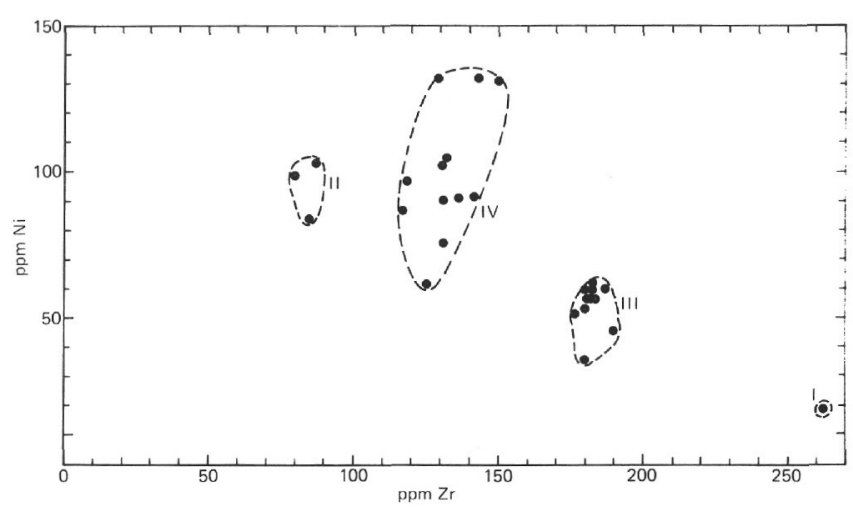

Figure 6. Ni versus Zr for Site 407 basalts.

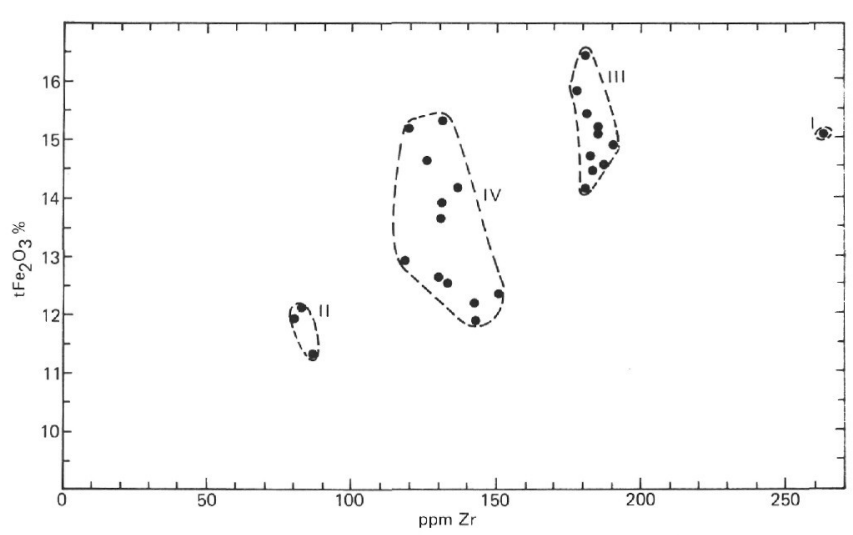

Figure 7. Total iron (as $\mathrm{Fe}_{2} \mathrm{O}_{3}$ ) versus $\mathrm{Zr}$ for Site 407 basalts.

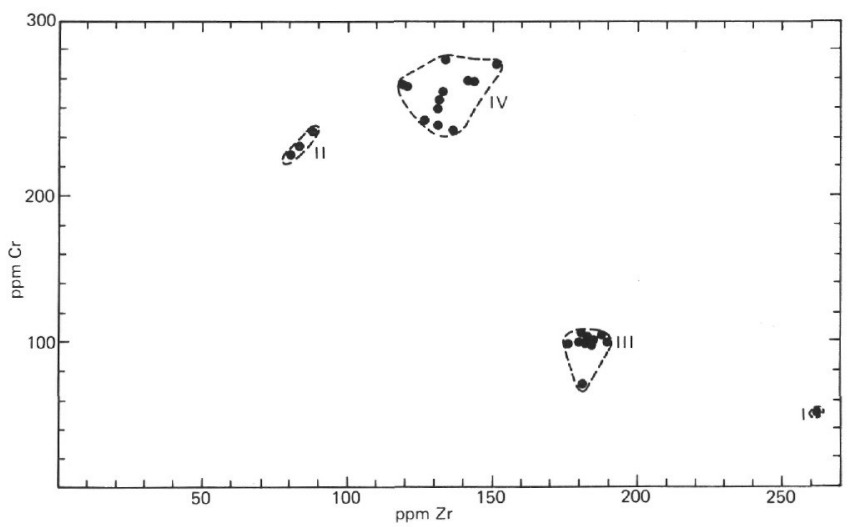

Figure 8. Cr versus $\mathrm{Zr}$ for Site 407 basalts.

major- and trace-element behavior within the lava sequence, all "normalized" to $\mathrm{Zr}$ as a fractionation index.

Figure 4 shows the variation in normative plagioclase composition, and there is a clear correlation with $\mathrm{Zr}$. The four geochemical units are clearly brought out, and the normative feldspar compositons agree fairly well with the modal values. This is not surprising since the feldspars have remained fairly resistant to alteration at this site. Although Units I and III could be related by crystal fractionation, it is unlikely that Units II, IV, and III could be so related, since considerable amounts of plagioclase (in addition to olivine 


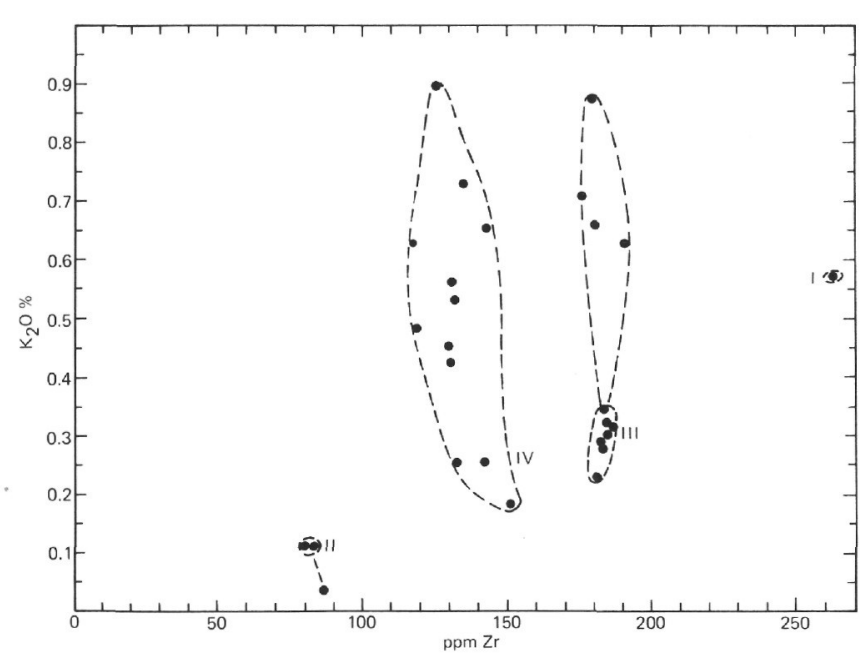

Figure 9. $\mathrm{K}_{2} \mathrm{O}$ versus $\mathrm{Zr}$ for Site 407 basalts. Note extreme dispersion in lower units, resulting from alteration effects.

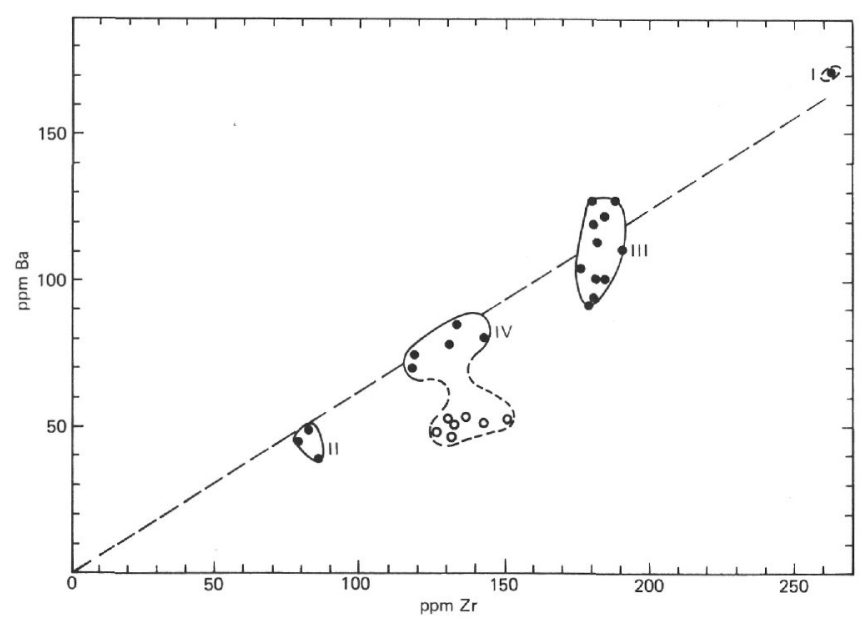

Figure 10. Ba versus $\mathrm{Zr}$ for Site 407 basalts, showing approximate linear correlation with zero intercept. Note increased dispersion in lower units, resulting from alteration.

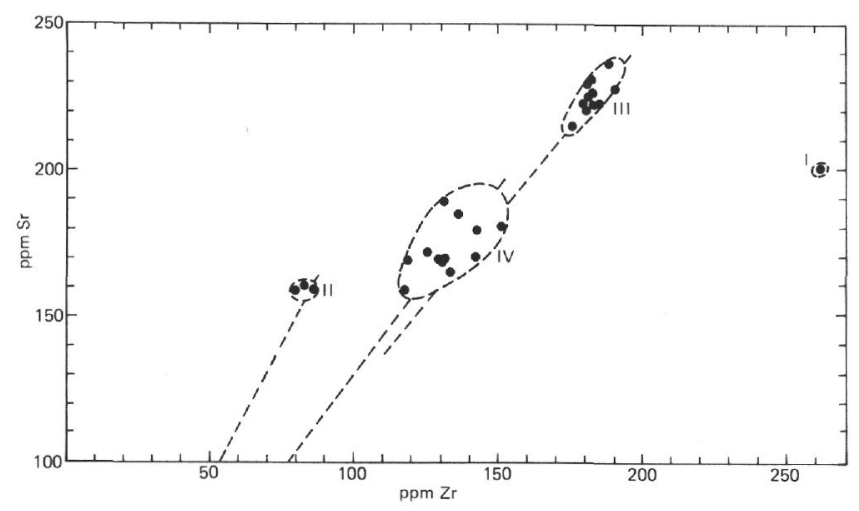

Figure 11. Sr versus Zr for Site 407 basalts. Dashed lines indicate different $\mathrm{Sr} / \mathrm{Zr}$ ratios with zero intercept.

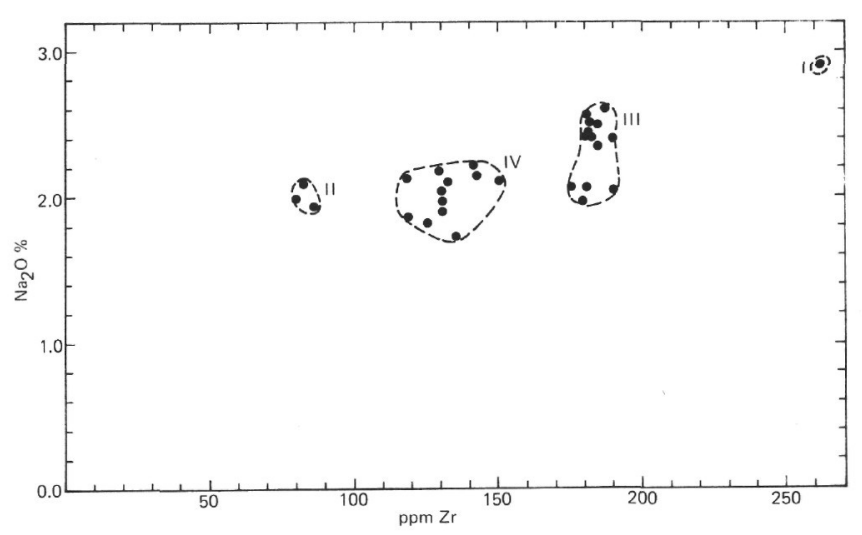

Figure 12. $\mathrm{Na}_{2} \mathrm{O}$ versus $\mathrm{Zr}$ for Site 407 basalts.

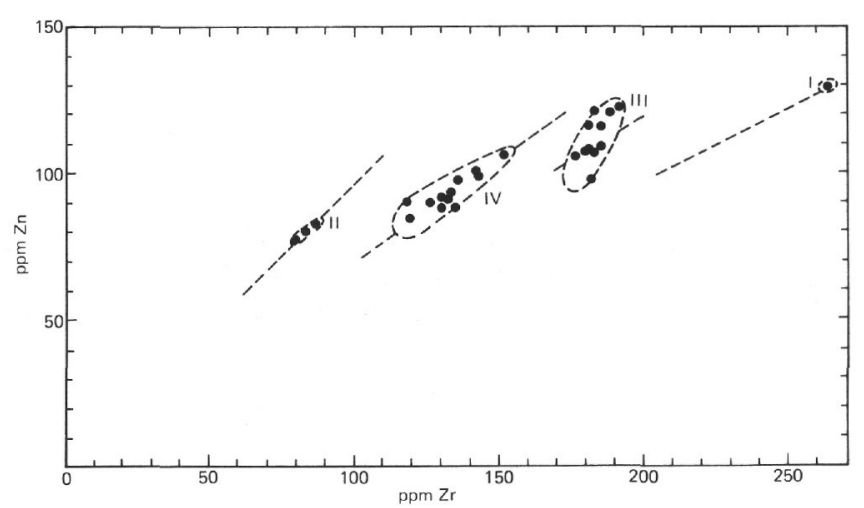

Figure 13. $Z n$ versus $Z r$ for Site 407 basalts. Correlation is approximately linear, but intercepts the $Z n$ axis. Dashed lines have zero intercept.

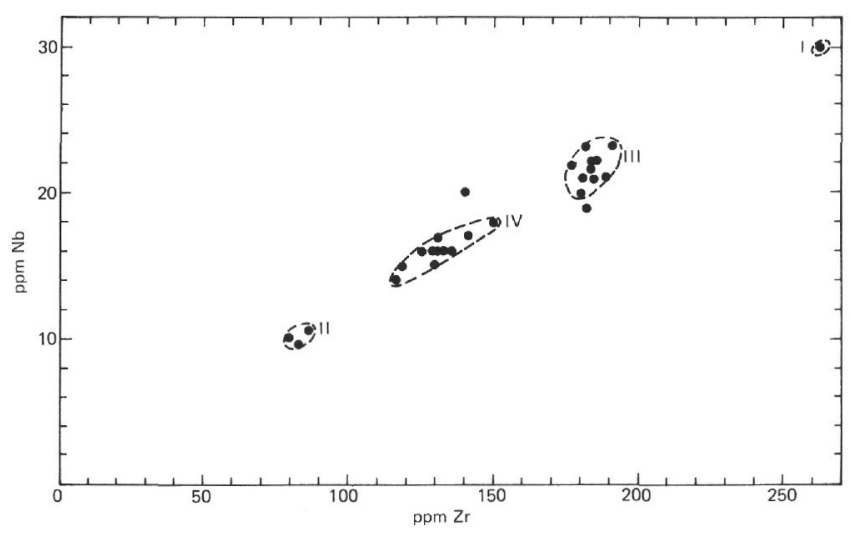

Figure 14. Nb versus $\mathrm{Zr}$ for Site 407 basalts, illustrating good linear correlation with zero intercept.

and clinopyroxene) would have to be removed to increase the $\mathrm{Zr}$ content in Unit IV and Unit III liquids to the observed levels, yet the normative plagioclase content decreased by only about $5 \mathrm{~mol}$ per cent An between Unit II and Unit III.

$\mathrm{MgO}$ and $\mathrm{Ni}$ show a clear negative correlation with $\mathrm{Zr}$ (Figures 5 and 6), and $\mathrm{Fe}_{2} \mathrm{O}_{3}$ shows a positive correlation (Figure 7), at least between the different units. However, 


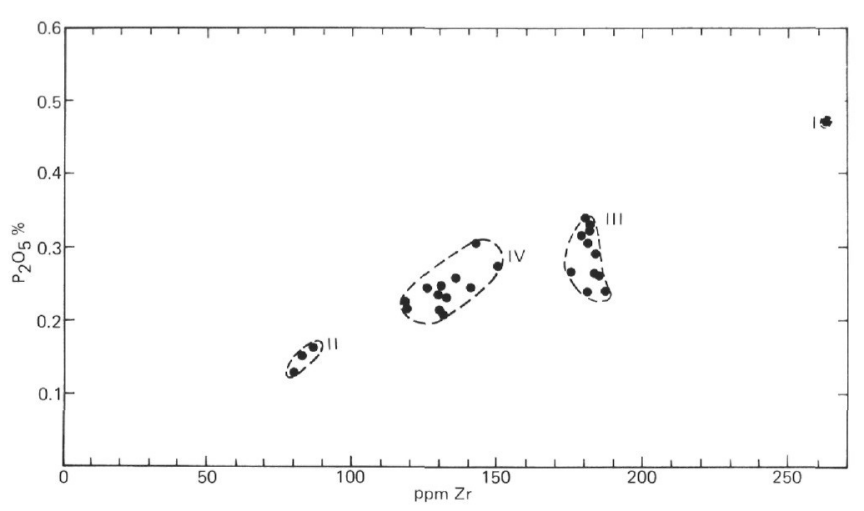

Figure 15. $\mathrm{P}_{2} \mathrm{O}_{5}$ versus $\mathrm{Zr}$ for Site 407 basalts. Correlation is approximately linear, with zero intercept.

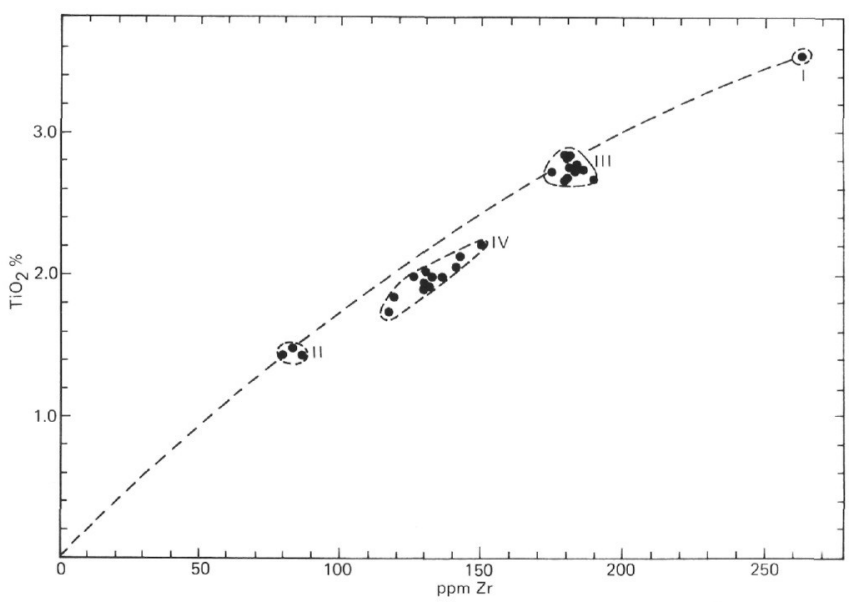

Figure 16. $\mathrm{TiO}_{2}$ versus $\mathrm{Zr}$ for Site 407 basalts.

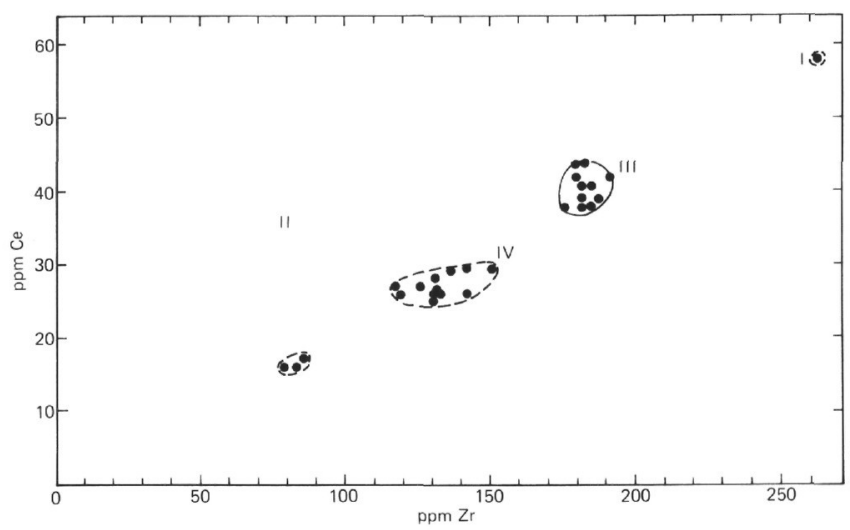

Figure 17. Ce versus $\mathrm{Zr}$ for Site 407 basalts. Correlation is approximately linear with zero intercept.

there is a considerable scatter of points within Unit III and especially Unit IV for these elements which is unrelated to $\mathrm{Zr}$. This within-unit scatter is partly real, since it is apparent also from the French and Russian major-element analyses but some may be due to mineralogical effects changing XRF response in the more altered rocks. It most probably reflects

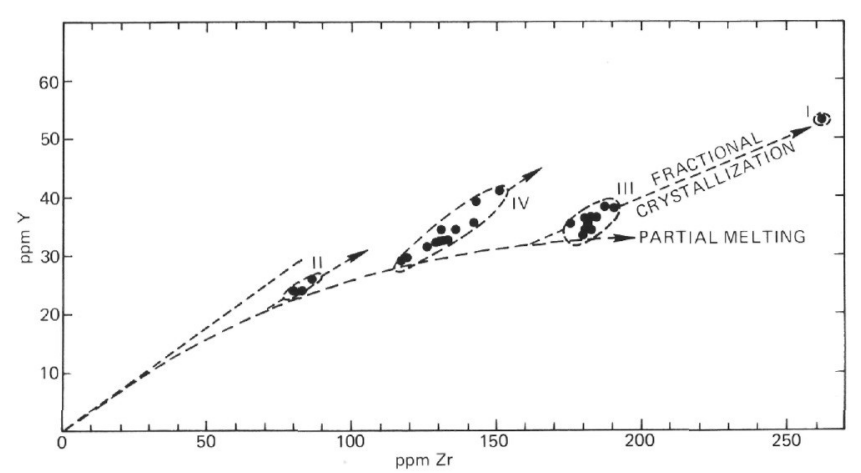

Figure 18. Y versus $\mathrm{Zr}$ for Site 407 basalts. Each unit has different $Y / Z r$ ratio with approximate zero intercept, but three units can be related by a partial melting curve ( $Y$ being retained in the source).

the increasing alteration and mobility of $\mathrm{Mg}, \mathrm{Fe}$, and $\mathrm{Ni}$ with depth in Site 407. This also means that it is inadvisable to use $\mathrm{Mg} / \mathrm{Fe}$ ratio as a precise index of differentiation under conditions of mild alteration. By contrast, there is much less scatter in $\mathrm{Cr}$ values within each unit (Figure 8). This could mean that $\mathrm{Cr}$ is much less mobile during alteration, and more specifically, probably reflects the fact that $\mathrm{Cr}$ is located in clinopyroxene and spinel which are relatively little altered, whereas $\mathrm{Mg}, \mathrm{Fe}$, and $\mathrm{Ni}$ are concentrated (relatively) in olivine which is rather badly altered in Site 407 lavas. If $\mathrm{Cr}$ values are real, it implies that the high- $\mathrm{Cr}$ Unit IV lavas cannot be derived by crystal differentiation from the more primitive Unit II lavas.

Other elements are known to be much more mobile than $\mathrm{Mg}, \mathrm{Fe}$, and $\mathrm{Ni}$ during low-grade alteration of basalts (Hart et al., 1973; Wolery and Sleep, 1976). $\mathrm{K}_{2} \mathrm{O}$, being incompatible, should increase linearly with $\mathrm{Zr}$; but a $\mathrm{K}_{2} \mathrm{O}$ versus $\mathrm{Zr}$ plot (Figure 9) shows that while there is a weak relationship, $\mathrm{K}_{2} \mathrm{O}$ values range over an order of magnitude in the lavas from the lower part of the core (Units III and IV). This is clearly an alteration phenomenon. A plot of $\mathrm{Rb}$ versus $\mathrm{Zr}$ would show even greater variations.

Barium (Figure 10) appears to be much more stable than $\mathrm{K}$ and $\mathrm{Rb}$. There is a greater scatter in Units III and IV which may be ascribed to alteration, but overall there is a good linear relationship between $\mathrm{Ba}$ and $\mathrm{Zr}$ which approximates to be chondritic ratio.

A plot of strontium versus zirconium (Figure 11) shows that the points for each unit are grouped rather more closely than those for barium, with the implication that $\mathrm{Sr}$ is less mobile. Since phenocrystic plagioclases are fairly fresh in Site 407 lavas, this more coherent behavior is understandable. Sr increases with $\mathrm{Zr}$ in Units II, IV, and III, but note that the relationship is not linear and that each unit has a different $\mathrm{Sr} / \mathrm{Zr}$ ratio. Sr appears to be behaving more compatibly than $\mathrm{Zr}$. Unit I has a distinctly lower $\mathrm{Sr} / \mathrm{Zr}$ ratio, which would be consistent with the derivation of Unit I lavas from magmas of composition similar to Unit III by a process of crystal fractionation involving plagioclase separation.

Sodium (Figure 12) increases only slightly with increasing $\mathrm{Zr}$, and is clearly not behaving as an 
incompatible element. Its abundance would appear to be controlled by one or more of the major mantle phases contributing to the partial melt of each magma batch.

The behavior of zinc (Figure 13) is not unlike that of Sr or $\mathrm{Na}_{2} \mathrm{O}$, and there is less dispersion. There is definite positive correlation with $\mathrm{Zr}$, but a best-fit line through all the points would intersect the ordinate at about $60 \mathrm{ppm} \mathrm{Zn}$. Each unit has a different $\mathrm{Zn} / \mathrm{Zr}$ ratio, and at least in Units II and IV, the points are spread out along the line of constant $\mathrm{Zn} / \mathrm{Zr}$ ratio for that unit. The implication would seem to be that zinc is not behaving incompatibly; and at least in the generation of the initial magma batch in each of these units, its bulk distribution coefficient must be close to unity.

The final group of elements (Figures 14 through 18) are all regarded as being relatively immobile during low-grade metamorphism of basaltic rocks (cf. Pearce and Cann 1973; Floyd and Winchester 1975). Niobium (Figure 14) and phosphorus (Figure 15) exhibit good positive linear correlation with zirconium, with relatively little scatter. The observed scatter in fact may result from alteration affecting the abundance of major elements such as $\mathrm{Mg}, \mathrm{Fe}$, and $\mathrm{Si}$ in the total matrix as much as any real variation in the ratio between these elements. The line in each case passes through zero, and it would appear that both $\mathrm{Nb}$ and $\mathrm{P}$ are behaving as ideally incompatible elements. Furthermore, the $\mathrm{Zr} / \mathrm{Nb}$ ratio $(8.5)$ and the $\mathrm{Zr} / \mathrm{P}$ ratio $(0.135)$ probably reflect the ratios in the mantle source which gave rise to Site 407 basalts.

A good correlation is also found between $\mathrm{TiO}_{2}$ and $\mathrm{Zr}$ (Figure 16). In this case, however, there is a slight curvature in the relationship, indicating that $\mathrm{Ti}$ is behaving more compatibly than $\mathrm{Zr}$, and may either have been retained in the source during partial melting, or been removed from the magma by separation of a Ti-bearing phase such as clinopyroxene. Separation of a Ti-rich phase such as titanomagnetite is unlikely to have occurred, since this would have reduced the Ti contents of the more fractionated lavas (Units III and I) much more drastically. Similar slightly convex curved trends between $\mathrm{Ti}$ and $\mathrm{Zr}$ are recorded in other fractionated basalt suites (Tarney et al., 1977) where the compositional relationships have been interpreted in terms of partial melting. Note that the basalts of Unit IV lie below the curve joining the other three units. It is possible that the source for Unit IV basalts had a slightly lower $\mathrm{Ti} / \mathrm{Zr}$ ratio at the time of generation.

Rare-earth element data provide valuable constraints on the possible mechanisms of generation of ocean basalts, and REE ratios have been extensively used by Schilling (1973, $1975 \mathrm{~b}$ ) in support of the mantle plume model for Iceland and the Reykjanes Ridge. Data for the light-RE's Ce and La are given in Table 2, along with data for $\mathrm{Y}$, which closely mirrors the heavy RE's in its behavior. A plot of Ce versus $\mathrm{Zr}$ (Figure 17) demonstrates a good linear relationship, with zero intercept, and indicates that $\mathrm{Ce}$ is behaving as an ideal incompatible element. The $\mathrm{Zr} / \mathrm{Ce}$ ratio of 4.7 probably reflects the ratio in the mantle source. This is rather lower than the $\mathrm{Zr} / \mathrm{Ce}$ ratio in chondritic meteorites (about 7), and indicates that the mantle source which gave rise to the different basalt lava units in Hole 407 is uniform with regard to $\mathrm{Ce} / \mathrm{Zr}$, and that it is slightly enriched in $\mathrm{Ce}$ (relative to $\mathrm{Zr}$ ) compared with a chondritic mantle.
The behavior of yttrium is rather different (Figure 18). Units II, IV, and III have different $\mathrm{Zr} / \mathrm{Y}$ ratios, and all ratios are higher than chondritic (about 2.8). However, the data points for each unit fall fairly closely about lines with zero intercept. In particular, Unit I has the same $\mathrm{Zr} / \mathrm{Y}$ ratio as Unit III basalts, which could be coincidental, but could also imply consanguinity. A plot of Ce versus Y (Figure 19) gives a good indication of the probable nature of the REE patterns for these four basalt units. All would classify as transitional basalts, in that their REE patterns are clearly light-RE enriched, and there are distinct groupings for each unit. The variable light-RE enrichment is not, however, a consequence of any variation in $\mathrm{Ce}$, but rather of variations in $\mathrm{Y}$. One explanation might be that the source that gave rise to Units II, IV, and (III + I) basalts had different $\mathrm{Zr} / \mathrm{Y}$ ratios, but constant $\mathrm{Zr} / \mathrm{Ce}$ ratio. However, since $\mathrm{Y}$ does increase with $\mathrm{Zr}$, although not in a linear fashion, an alternative explanation might be that $\mathrm{Y}$ is acting in a more compatible fashion. Figure 18 illustrates the probable relationship. The mantle source would have a $\mathrm{Zr} / \mathrm{Y}$ ratio close to chondritic, but $\mathrm{Y}$ would be progressively retained in the source with smaller degrees of partial melting. Each batch of magma transferred toward the surface might differentiate to a minor degree in subcrustal magma chambers, but this would not appreciably affect $\mathrm{Zr} / \mathrm{Ce}$, $\mathrm{Zr} / \mathrm{Y}$, or $\mathrm{Ce} / \mathrm{Y}$ ratios, unless there was appreciable separation of plagioclase or clinopyroxene. On the other hand, $\mathrm{Y}$ could be retained quite effectively in a mantle source with residual garnet or clinopyroxene. Clinopyroxene is preferred because garnet has a high partition coefficient for $\mathrm{Y}$ and would give rise to a greater $\mathrm{Y}$ depletion than observed. One difficulty with relating the different geochemical units by partial melting of a uniform source is that the $\mathrm{Fe} / \mathrm{Mg}$ ratio of even the most primitive Unit III basalts are too high to have been in equilibrium with mantle peridotite. Thus, it would be necessary to postulate olivine fractionation before eruption to raise $\mathrm{Fe} / \mathrm{Mg}$ ratios to that of the erupted lavas. The primary Unit III magma would then have lower $\mathrm{Zr}$ and $\mathrm{Y}$ concentrations than those predicted by the schematic partial melting curve of Figure 18. The source of Unit III lavas may have had a higher $\mathrm{Zr} / \mathrm{Y}$ ratio, or there may have been a small amount of residual garnet.

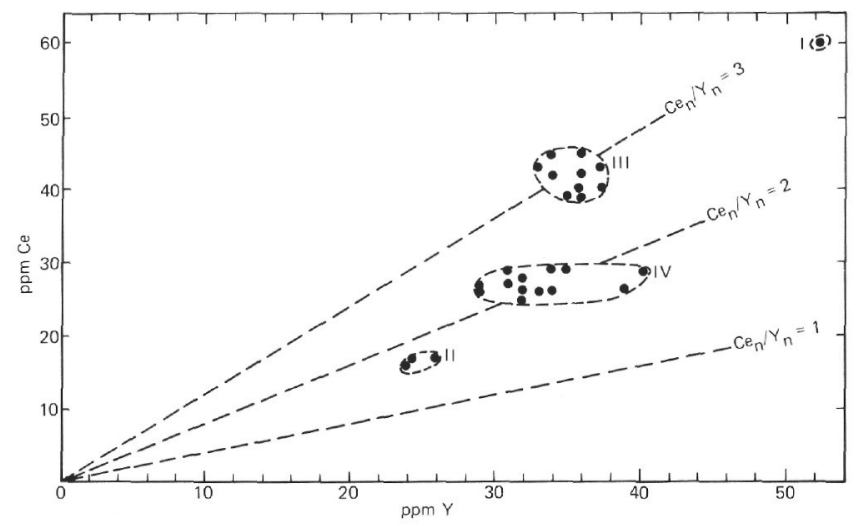

Figure 19. Ce versus $Y$ for Site 407 basalts. Lines indicate chrondrite-normalized $\mathrm{Ce} / Y$ ratio values. 
In summary, it would appear that all Site 407 basalts could be derived from a mantle source which was chemically rather uniform with respect to many incompatible elements. Differences in basalt rare-earth patterns can be largely attributed to heavy-RE retention in the mantle source with smaller degrees of partial melting, although there is a possibility of differing $\mathrm{Zr} / \mathrm{Y}$ ratios in the source regions of the various geochemical units. Because of the incoherent behavior of $\mathrm{Rb}$ resulting from the secondary alteration, it is difficult to test whether $\mathrm{Rb} / \mathrm{Sr}$ ratios might correlate with $\mathrm{Ce} / \mathrm{Y}$ ratios and contribute to a relationship between ${ }^{87} \mathrm{Sr} /{ }^{86} \mathrm{Sr}$ and LREE/HREE ratios such as has been observed in recent basalts from Iceland and the Reykjanes Ridge (Schilling 1973; Hart et al., 1973). Nevertheless, in spite of the alteration, a sympathetic downhole variation in $\mathrm{Rb} / \mathrm{Sr}$ and $\mathrm{Ce}_{\mathrm{N}} / \mathrm{Y}_{\mathrm{N}}$ is apparent from Figure 2. Geochemical Units II, III, and IV represent different partial melts with minor amounts of crystal differentiation superimposed. Unit I could be derived from a magma similar to Unit III by more extensive crystal fractionation in a sub-crustal magma chamber.

\section{SITES 408 AND 409}

The geochemistry of the basalts of these two sites will be described together and compared with Site 407 basalts, since the sites all lie on the same mantle flow line (Figure 1).

Site 408 is on the west flank of the Reykjanes Ridge at $63^{\circ} 22.66^{\prime} \mathrm{N}, 28^{\circ} 54.71^{\prime} \mathrm{W}$, at a water depth of 1624 meters. About 33 meters of vesicular aphyric basalt was cored. The basalt was intercalated with sediment and breccia, and lay beneath 322 meters of sediment. The site lies on magnetic anomaly 6 (about $20 \mathrm{~m} . \mathrm{y}$.). Most of the basalts are aphyric or contain only sparse olivine and plagioclase phenocrysts. Alteration is widespread, and few fresh olivines remain. The vesicles are filled with chlorite, zeolite, calcite, and smectite. In the limited section cored, there are no major geochemical breaks of the type seen in Hole 407, although there is an abrupt change in the concentrations of some elements in the upper part of Core 37. Two major magnetic units can also be distinguished, with an inclination of $58^{\circ}$ for the upper unit (Cores 35 and 36 ) and $83^{\circ}$ for the lower unit (Cores 37 and 38). This could indicate a time gap in the eruption of the lavas, but it may also reflect differences in the degree and type of alteration suffered by the upper and lower parts of the lava sequence. In general, the geochemical differences between Units I and II at Site 408 are relatively small, and for reason of clarity the two units are not represented separately in the inter-element plots.

Site 409 is close to the crest of the Reykjanes Ridge at $62^{\circ} 36.98^{\prime} \mathrm{N}, 25^{\circ} 57.17^{\prime} \mathrm{W}$, in a water depth of only 832 meters, and was drilled in relatively young $(2.3 \mathrm{~m} . \mathrm{y}$.$) crust$ on anomaly $2^{\prime}$. About 240 meters of vesicular basalt was cored, most of it relatively fresh. The basalts range from aphyric to olivine-phyric and olivine-plagioclase phyric, and in a few there are microcumulate clinopyroxenes. None of the lavas is strongly porphyritic, however. A large number of units can be distinguished on petrographic criteria. On geochemical grounds there are three significant breaks in the sequence, providing only four chemical units. Of these, however, the major break occurs between Units 2 and 3 at the base of Core 13; the upper two units have significantly lower incompatible element abundances than the lower two. In the following inter-element plots, only these two major divisions are distinguished. The main emphasis will be directed toward comparing the geochemistry of these basalts with those at Sites 407 and 408. In spite of the much larger number of samples analyzed from Site 409, there is much less dispersion apparent in the inter-element plots than in the basalts from the other two Reykjanes sites. This would seem to be a direct result of the fresher nature of the basalts at Site 409. Nevertheless, there is rather more scatter in the lower unit than in the upper unit, which could reflect a greater degree of low-grade alteration than is apparent from the shipboard petrographic observations.

\section{Geochemistry}

Analyses of Site 408 and Site 409 basalts are presented in Tables 3 and 4 , respectively. Site 408 basalts are distinctly olivine-normative (Figure 20), and show rather a wide range in the proportion of hypersthene, some verging on undersaturation. Some of this variation could of course be a result of alteration. Site 409 basalts fall into two distinct normative groups (Figure 20). Basalts from the upper unit plot close to the Di-Hy join and are slightly olivine- or quartz-normative. The samples from the lower unit, however, are all olivine-normative, and like those from Site 408 , show a wide variation in the proportion of hypersthene - some samples again are slightly nepheline-normative. Like Site 408 basalts, the lower unit of Site 409 is more altered, which could contribute to the trend toward undersaturation.

The upper unit at Site 409 has lower incompatible-element abundances and higher $\mathrm{Mg} / \mathrm{Fe}$ ratios than the lower unit, which could suggest that basalts from the upper unit are the more primitive. On the other hand, the lower unit has higher $\mathrm{Ni}$ and distinctly higher $\mathrm{Cr}$ abundances (Table 4) than the upper unit. This precludes that the two could be related directly by crystal differentiation, although it is conceivable that separation of olivine and spinel could have reduced the $\mathrm{Ni}$ and $\mathrm{Cr}$ contents of the upper unit before eruption. It is notable, however, that the basalts from the lower unit of Site 409, basalts from Site 408, and basalts from the lower unit of Site 407 have similar higher $\mathrm{Cr}$ contents, and all plot nearer the Di-Ol join on a normative Ol-Di-Hy diagram than do basalts from the other units. Thus, there is a better correlation between $\mathrm{Cr}$ and $\mathrm{Mg} / \mathrm{Fe}$ ratio. This further suggests that the normative compositions of Site 407,408 , and 409 basalts, as depicted in Figures 3 and 20, are to a large extent valid.

Strontium is higher in the lower unit of Site 409 than in the upper unit (Figure 21), and there is a reasonable linear correlation between $\mathrm{Sr}$ and $\mathrm{Zr}$ in these two units and the lower two units at Site 407, suggesting that Sr could be behaving incompatibly in some of the Reykjanes basalts. It is unlikely that the two units at Site 409 could be related by plagioclase fractionation, otherwise $\mathrm{Sr}$ would be lower in the lower unit. Since the $\mathrm{Cr}$ and Ni values in the two units also preclude a relationship through separation of mafic phases, it is most likely that they are independent partial melt batches. The lower unit at Site 409 contains some 
TABLE 3

Analyses of Basalts From Hole 408, Leg 49

\begin{tabular}{|c|c|c|c|c|c|c|c|c|c|c|c|c|}
\hline $\begin{array}{c}\text { Core-Section } \\
\text { Interval }(\mathrm{cm}) \\
\text { Piece }\end{array}$ & $\begin{array}{c}35-1 \\
108-110 \\
8\end{array}$ & $\begin{array}{c}36-1 \\
100-103 \\
10 \mathrm{~B}\end{array}$ & $\begin{array}{c}36-2 \\
12-14 \\
18\end{array}$ & $\begin{array}{c}36-3 \\
46-49 \\
4\end{array}$ & $\begin{array}{c}36-4 \\
37-40 \\
3 \mathrm{C}\end{array}$ & $\begin{array}{c}36-5 \\
44-47 \\
4 \mathrm{~A}\end{array}$ & $\begin{array}{c}37-1 \\
30-35 \\
-\end{array}$ & $\begin{array}{c}37-1 \\
114-120 \\
-\end{array}$ & $\begin{array}{c}37-2 \\
128-133 \\
18\end{array}$ & $\begin{array}{c}37-3 \\
118-122 \\
-\end{array}$ & $\begin{array}{c}38-1 \\
119-122 \\
-\end{array}$ & $\begin{array}{c}38-3 \\
130-134 \\
-\end{array}$ \\
\hline $\mathrm{SiO}_{2}$ & 47.14 & 46.04 & 45.84 & 47.51 & 47.62 & 47.25 & 48.66 & 48.93 & 47.60 & 47.48 & 47.17 & 47.28 \\
\hline $\mathrm{TiO}_{2}$ & 1.55 & 1.47 & 1.52 & 1.53 & 1.58 & 1.36 & 1.61 & 1.55 & 2.23 & 2.20 & 1.72 & 1.94 \\
\hline $\mathrm{Al}_{2} \mathrm{O}_{3}$ & 12.6 & 13.3 & 13.5 & 13.5 & 13.3 & 13.5 & 13.9 & 13.2 & 12.8 & 12.8 & 13.3 & 13.0 \\
\hline $\mathrm{Fe}_{2} \mathrm{O}_{3}$ & 13.35 & 11.19 & 11.38 & 11.04 & 13.75 & 11.43 & 11.43 & 12.23 & 13.73 & 13.74 & 12.67 & 13.24 \\
\hline $\mathrm{MnO}$ & 0.26 & 0.19 & 0.16 & 0.14 & 0.19 & 0.14 & 0.15 & 0.12 & 0.15 & 0.17 & 0.16 & 0.19 \\
\hline $\mathrm{MgO}$ & 6.21 & 7.34 & 6.67 & 8.58 & 7.60 & 8.99 & 9.48 & 11.22 & 10.59 & 10.31 & 11.61 & 10.83 \\
\hline $\mathrm{CaO}$ & 12.95 & 14.12 & 13.88 & 12.37 & 11.76 & 12.21 & 11.36 & 10.58 & 9.95 & 10.86 & 10.64 & 10.95 \\
\hline $\mathrm{Na}_{2} \mathrm{O}$ & 1.76 & 2.01 & 1.96 & 2.15 & 1.96 & 2.03 & 2.19 & 2.11 & 2.11 & 2.07 & 1.85 & 1.96 \\
\hline $\mathrm{K}_{2} \mathrm{O}$ & 0.68 & 0.43 & 0.47 & 0.39 & 0.61 & 0.48 & 0.23 & 0.21 & 0.22 & 0.15 & 0.05 & 0.10 \\
\hline $\mathrm{P}_{2} \mathrm{O}_{5}$ & 0.168 & 0.190 & 0.227 & 0.180 & 0.177 & 0.158 & 0.200 & 0.153 & 0.244 & 0.274 & 0.211 & 0.230 \\
\hline Total & 96.7 & 96.3 & 95.6 & 97.4 & 98.5 & 97.6 & 99.2 & 100.3 & 99.6 & 100.1 & 99.4 & 99.7 \\
\hline
\end{tabular}

Trace elements in ppm

\begin{tabular}{|c|c|c|c|c|c|c|c|c|c|c|c|c|}
\hline \multicolumn{13}{|c|}{2} \\
\hline $\mathrm{Ni}$ & 71 & 87 & 75 & 112 & 61 & 90 & 101 & 98 & 102 & 101 & 144 & 114 \\
\hline $\mathrm{Cr}$ & 282 & 232 & 265 & 274 & 266 & 302 & 289 & 316 & 288 & 266 & 288 & 310 \\
\hline $\mathrm{Ga}$ & 17 & 20 & 19 & 18 & 19 & 19 & 19 & 19 & 21 & 21 & 20 & 18 \\
\hline $\mathrm{Rb}$ & 12 & 5 & 6 & 4 & 9 & 6 & 2 & 2 & 1 & $<1$ & $<1$ & 1 \\
\hline $\mathrm{Sr}$ & 174 & 253 & 228 & 208 & 188 & 232 & 185 & 164 & 192 & 196 & 207 & 185 \\
\hline $\mathrm{Y}$ & 24 & 23 & 22 & 24 & 24 & 21 & 27 & 22 & 31 & 32 & 24 & 27 \\
\hline $\mathrm{Zr}$ & 107 & 106 & 102 & 106 & 106 & 95 & 120 & 105 & 151 & 145 & 117 & 127 \\
\hline $\mathrm{Nb}$ & 16 & 17 & 16 & 15 & 14 & 13 & 16 & 14 & 19 & 17 & 15 & 16 \\
\hline $\mathrm{Ba}$ & 50 & 53 & 39 & 43 & 47 & 53 & 69 & 70 & 118 & 97 & 55 & 78 \\
\hline $\mathrm{La}$ & 9 & 8 & 9 & 10 & 11 & 9 & 10 & 9 & 12 & 14 & 9 & 11 \\
\hline $\mathrm{Ce}$ & 25 & 22 & 23 & 21 & 24 & 22 & 26 & 21 & 30 & 33 & 26 & 26 \\
\hline $\mathrm{Pb}$ & 5 & 1 & 3 & 4 & 4 & 11 & 4 & 2 & 5 & 3 & $<1$ & 3 \\
\hline Th & -1 & -1 & 1 & 2 & -1 & 1 & -1 & 2 & 1 & $<1$ & 2 & 1 \\
\hline $\mathrm{Zn}$ & 81 & 85 & 82 & 83 & 77 & 67 & 84 & 77 & 97 & 93 & 82 & 86 \\
\hline
\end{tabular}

Selected element ratios

$\begin{array}{lccccccccccccc}\mathrm{K} / \mathrm{Rb} & 470.4 & 713.9 & 650.2 & 809.3 & 562.6 & 664.1 & 954.6 & 871.6 & 1826.2 & - & - & 830.1 \\ \mathrm{Rb} / \mathrm{Sr} & 0.069 & 0.020 & 0.026 & 0.019 & 0.048 & 0.026 & 0.011 & 0.012 & 0.005 & - & - & 0.005 \\ \mathrm{Ba} / \mathrm{Sr} & 0.29 & 0.21 & 0.17 & 0.21 & 0.25 & 0.23 & 0.37 & 0.43 & 0.61 & 0.49 & 0.27 & 0.42 \\ \mathrm{Zr} / \mathrm{Nb} & 6.7 & 6.2 & 6.4 & 7.1 & 7.6 & 7.3 & 7.5 & 7.5 & 7.9 & 85 . & 7.8 & 7.9 \\ \mathrm{Zr} / \mathrm{Ce} & 43 . & 4.8 & 4.4 & 5.0 & 4.4 & 4.3 & 4.6 & 5.0 & 5.0 & 4.4 & 4.5 & 4.9 \\ \mathrm{Zr} / \mathrm{Y} & 4.5 & 4.6 & 4.6 & 4.4 & 4.4 & 4.5 & 4.4 & 4.8 & 4.9 & 4.5 & 4.9 & 4.7 \\ \mathrm{CeN} / \mathrm{YN} & 2.55 & 2.34 & 2.55 & 2.14 & 2.44 & 2.56 & 2.35 & 2.33 & 2.36 & 2.52 & 2.65 & 2.35 \\ \mathrm{tFe} / \mathrm{Mg} & 2.5 & 1.8 & 2.0 & 1.5 & 2.1 & 1.5 & 1.4 & 1.3 & 1.5 & 1.5 & 1.3 & 1.4\end{array}$

C.I.P.W. Norm

\begin{tabular}{|c|c|c|c|c|c|c|c|c|c|c|c|c|}
\hline$Q$ & 0.0 & 0.0 & 0.0 & 0.0 & 0.0 & 0.0 & 0.0 & 0.0 & 0.0 & 0.0 & 0.0 & 0.0 \\
\hline $\mathrm{Or}$ & 4.2 & 2.7 & 2.9 & 2.4 & 3.7 & 2.9 & 1.4 & 1.2 & 1.3 & 0.9 & 0.3 & 0.6 \\
\hline $\mathrm{Ab}$ & 15.6 & 15.8 & 17.4 & 18.9 & 17.0 & 17.8 & 18.9 & 18.0 & 18.1 & 17.7 & 15.9 & 16.8 \\
\hline An & 25.6 & 27.3 & 28.1 & 27.0 & 26.4 & 27.3 & 27.8 & 26.1 & 25.1 & 25.5 & 28.4 & 26.8 \\
\hline $\mathrm{Ne}$ & 0.0 & 1.1 & 0.1 & 0.0 & 0.0 & 0.0 & 0.0 & 0.0 & 0.0 & 0.0 & 0.0 & 0.0 \\
\hline Di & 33.6 & 36.8 & 35.4 & 28.8 & 26.7 & 28.0 & 22.9 & 20.9 & 19.0 & 22.2 & 19.4 & 21.7 \\
\hline $\mathrm{Hy}$ & 11.6 & 0.0 & 0.0 & 7.2 & 12.3 & 6.3 & 15.6 & 17.4 & 18.4 & 15.1 & 16.8 & 14.8 \\
\hline $\mathrm{Ol}$ & 3.4 & 10.9 & 10.3 & 10.2 & 7.9 & 12.5 & 7.7 & 10.8 & $10 ? 5$ & 11.3 & 13.1 & 12.5 \\
\hline $\mathrm{Mt}$ & 2.4 & 2.0 & 2.1 & 2.0 & 2.5 & 2.0 & 2.0 & 2.1 & 2.4 & 2.4 & 2.2 & 2.3 \\
\hline Il & 3.1 & 2.9 & 3.0 & 3.0 & 3.1 & 2.7 & 3.1 & 3.0 & 4.3 & 4.2 & 3.3 & 3.7 \\
\hline Ap & 0.4 & 0.5 & 0.6 & 0.4 & 0.4 & 0.4 & 0.5 & 0.4 & 0.6 & 0.7 & 0.5 & 0.6 \\
\hline
\end{tabular}

samples with anomalously high $\mathrm{Sr}$ values; this is most likely an alteration effect. Basalts from Site 408 also show rather a wide scatter in Sr contents, which may also reflect alteration.

A striking feature of all the Reykjanes basalts is the constancy in ratios $\mathrm{Ba} / \mathrm{Zr}$ (Figure 22), $\mathrm{P}_{2} \mathrm{O}_{5} / \mathrm{Zr}$ (Figure 23), $\mathrm{Nb} / \mathrm{Zr}$ (Figure 24), and $\mathrm{Ce} / \mathrm{Zr}$ (Figure 25) between the different sites. Since these ratios can vary quite markedly along the Mid-Atlantic Ridge (see below), this most likely reflects the ratios in the mantle source. Certainly these ratios seem to be independent of the type of basalt being produced - whether quartz-normative or olivine-normative and verging on undersaturation - and thus independent of the differing $\mathrm{P}, \mathrm{T}$, and $\mathrm{pH}_{2} \mathrm{O}$ conditions operating during their genesis. Moreover, since the basalts sampled were produced by spreading at the same ridge segment over 30 m.y., it implies a large volume of mantle with these constant ratios.

The Ce- $\mathrm{Zr}$ (Figure 25) plot is particularly interesting in view of the wide variation in $\mathrm{Ce} / \mathrm{Y}$ ratios observed at Site 
TABLE 4

Analyses of Basalts From Hole 409, Leg 49

\begin{tabular}{lccccccccccc}
\hline Core-Section & $7-6$ & $7-7$ & $8-1$ & $9-1$ & $9-3$ & $9-3$ & $10-1$ & $10-2$ & $10-3$ & $10-4$ \\
Interval $(\mathrm{cm})$ & $71-75$ & $3-4$ & $104-107$ & $135-140$ & $6-10$ & $137-140$ & $10-12$ & $16-20$ & $69-72$ & $91-94$ & $41-44$ \\
\multicolumn{1}{c}{ Piece } & 5 & 1 & 13 & 18 & 1 & 15 & 2 & 2 & 40 & 9 \\
\hline $\mathrm{SiO}_{2}$ & 49.53 & 49.10 & 49.20 & 49.93 & 50.54 & 50.15 & 50.20 & 48.76 & 48.26 & 49.90 & 49.76 \\
$\mathrm{TiO}_{2}$ & 1.40 & 1.30 & 1.40 & 1.50 & 1.51 & 1.23 & 1.25 & 1.25 & 1.24 & 1.26 & 1.38 \\
$\mathrm{Al}_{2} \mathrm{O}_{3}$ & 14.0 & 14.3 & 14.4 & 14.3 & 14.2 & 14.3 & 14.4 & 14.7 & 14.4 & 14.3 & 14.4 \\
$\mathrm{Fe}_{2} \mathrm{O}_{3}$ & 12.13 & 12.36 & 12.13 & 12.97 & 12.86 & 12.12 & 12.03 & 11.88 & 12.67 & 11.58 & 11.66 \\
$\mathrm{MnO}$ & 0.15 & 0.18 & 0.20 & 0.22 & 0.22 & 0.17 & 0.17 & 0.19 & 0.18 & 0.17 & 0.18 \\
$\mathrm{MgO}$ & 8.02 & 7.79 & 6.18 & 5.77 & 6.24 & 8.56 & 8.42 & 7.00 & 6.39 & 8.53 & 8.06 \\
$\mathrm{CaO}$ & 11.41 & 11.86 & 12.10 & 12.03 & 11.94 & 11.77 & 11.77 & 12.28 & 12.02 & 11.69 & 11.83 \\
$\mathrm{Na} 2 \mathrm{O}$ & 2.12 & 2.17 & 2.32 & 2.08 & 2.12 & 2.03 & 2.10 & 2.03 & 2.06 & 2.02 & 2.15 \\
$\mathrm{~K}_{2} \mathrm{O}$ & 0.07 & 0.02 & 0.13 & 0.25 & 0.18 & 0.06 & 0.06 & 0.13 & 0.29 & 0.04 & 0.03 \\
$\mathrm{P}_{2} \mathrm{O}_{5}$ & 0.128 & 0.116 & 0.103 & 0.111 & 0.117 & 0.103 & 0.110 & 0.105 & 0.110 & 0.117 & 0.124 \\
$\mathrm{Total}$ & 99.0 & 99.2 & 98.2 & 99.1 & 99.9 & 100.5 & 100.6 & 98.3 & 97.7 & 99.6 & 99.6
\end{tabular}

Trace elements in ppm

\begin{tabular}{|c|c|c|c|c|c|c|c|c|c|c|c|}
\hline $\mathrm{Ni}$ & 77 & 76 & 127 & 71 & 81 & 73 & 76 & 73 & 56 & 71 & 70 \\
\hline $\mathrm{Cr}$ & 231 & 225 & 129 & 104 & 108 & 162 & 160 & 146 & 164 & 187 & 149 \\
\hline $\mathrm{Ga}$ & 19 & 19 & 19 & 19 & 20 & 17 & 17 & 16 & 17 & 17 & 19 \\
\hline $\mathrm{Rb}$ & 1 & -1 & 2 & 4 & 4 & 1 & 1 & 2 & 5 & 1 & $<1$ \\
\hline $\mathrm{Sr}$ & 86 & 84 & 91 & 95 & 96 & 83 & 83 & 86 & 97 & 85 & 87 \\
\hline $\mathrm{Y}$ & 29 & 27 & 29 & 31 & 32 & 25 & 26 & 25 & 24 & 25 & 26 \\
\hline $\mathrm{Zr}$ & 71 & 64 & 71 & 75 & 75 & 62 & 65 & 61 & 61 & 64 & 67 \\
\hline $\mathrm{Nb}$ & 8 & 7 & 9 & 9 & 9 & 8 & 8 & 8 & 6 & 8 & 9 \\
\hline $\mathrm{Ba}$ & 40 & 29 & 33 & 45 & 44 & 37 & 34 & 28 & 28 & 34 & 38 \\
\hline $\mathrm{La}$ & 6 & 4 & 6 & 6 & 4 & 5 & 4 & 4 & 4 & 4 & 6 \\
\hline $\mathrm{Ce}$ & 15 & 11 & 14 & 15 & 14 & 12 & 11 & 11 & 11 & 13 & 11 \\
\hline $\mathrm{Pb}$ & 5 & 3 & 4 & 2 & 5 & 3 & 3 & 5 & 2 & 1 & 3 \\
\hline Th & 1 & -1 & -1 & -1 & -1 & -1 & -1 & -1 & -1 & 1 & $<1$ \\
\hline $\mathrm{Zn}$ & 83 & 79 & 85 & 90 & 91 & 75 & 78 & 79 & 73 & 77 & 82 \\
\hline
\end{tabular}

\begin{tabular}{|c|c|c|c|c|c|c|c|c|c|c|c|}
\hline \multicolumn{12}{|c|}{ Selected element ratios } \\
\hline $\mathrm{K} / \mathrm{Rb}$ & 581.1 & 0.0 & 539.6 & 518.8 & 373.5 & 498.1 & 498.1 & 539.6 & 481.5 & 332.0 & - \\
\hline $\mathrm{Rb} / \mathrm{Sr}$ & 0.012 & 0.000 & 0.022 & 0.042 & 0.042 & 0.012 & 0.012 & 0.023 & 0.052 & 0.012 & - \\
\hline $\mathrm{Ba} / \mathrm{Sr}$ & 0.47 & 0.35 & 0.36 & 0.47 & 0.46 & 0.45 & 0.41 & 0.33 & 0.29 & 0.40 & 0.44 \\
\hline $\mathrm{Zr} / \mathrm{Nb}$ & 8.9 & 9.1 & 7.9 & 8.3 & 8.3 & 7.7 & 8.1 & 7.6 & 10.2 & 8.0 & 7.4 \\
\hline $\mathrm{Zr} / \mathrm{Ce}$ & 4.7 & 5.8 & 5.1 & 5.0 & 5.4 & 5.2 & 5.9 & 5.5 & 5.5 & 4.9 & 6.1 \\
\hline $\mathrm{Zr} / \mathrm{Y}$ & 2.5 & 2.4 & 2.5 & 2.4 & 2.3 & 2.5 & 2.5 & 2.4 & 2.5 & 2.6 & 2.6 \\
\hline $\mathrm{Ce}_{\mathrm{N}} / \mathrm{Y}_{\mathrm{N}}$ & 1.26 & 1.00 & 1.18 & 1.18 & 1.07 & 1.17 & 1.03 & 1.08 & 1.12 & 1.27 & 1.03 \\
\hline $\mathrm{tFe} / \mathrm{Mg}$ & 1.7 & 1.8 & 2.3 & 2.6 & 2.4 & 1.6 & 1.6 & 2.0 & 2.3 & 1.6 & 1.7 \\
\hline \multicolumn{12}{|c|}{ C.I.P.W. Norm } \\
\hline Q & 0.2 & 0.0 & 0.4 & 2.3 & 2.5 & 0.0 & 0.0 & 0.0 & 0.0 & 0.2 & 0.0 \\
\hline Or & 0.4 & 0.1 & 0.8 & 1.5 & 1.1 & 0.4 & 0.4 & 0.8 & 1.8 & 0.2 & 0.2 \\
\hline $\mathrm{Ab}$ & 18.3 & 18.7 & 20.2 & 17.9 & 18.2 & 17.3 & 17.9 & 17.7 & 18.1 & 17.3 & 18.4 \\
\hline An & 29.1 & 29.8 & 29.5 & 29.4 & 28.9 & 29.8 & 29.9 & 31.4 & 30.3 & 30.2 & 30.0 \\
\hline $\mathrm{Ne}$ & 0.0 & 0.0 & 0.0 & 0.0 & 0.0 & 0.0 & 0.0 & 0.0 & 0.0 & 0.0 & 0.0 \\
\hline Di & 22.8 & 24.1 & 26.1 & 25.5 & 25.1 & 23.1 & 22.9 & 25.1 & 25.4 & 22.7 & 23.5 \\
\hline $\mathrm{Hy}$ & 23.9 & 19.9 & 17.8 & 17.8 & 18.9 & 24.2 & 23.4 & 19.9 & 18.2 & 24.5 & 22.7 \\
\hline $\mathrm{Ol}$ & 0.0 & 2.4 & 0.0 & 0.0 & 0.0 & 0.6 & 0.8 & 0.3 & 1.2 & 0.0 & 0.2 \\
\hline $\mathrm{Mt}$ & 2.2 & 2.2 & 2.2 & 2.3 & 2.3 & 2.1 & 2.1 & 2.1 & 2.3 & 2.0 & 2.1 \\
\hline Il & 2.7 & 2.5 & 2.7 & 2.9 & 2.9 & 2.4 & 2.4 & 2.4 & 2.4 & 2.4 & 2.7 \\
\hline Ap & 0.3 & 0.3 & 0.3 & 0.3 & 0.3 & 0.3 & 0.3 & 0.3 & 0.3 & 0.3 & 0.3 \\
\hline
\end{tabular}

407. It is apparent that different $\mathrm{Ce} / \mathrm{Y}$ ratios characterize the various units at Sites 408 and 409, too (Figure 26), and imply that REE patterns in the Reykjanes basalts range from flat or slightly LREE-depleted to LREE-enriched $\left(\mathrm{Ce}_{\mathrm{n}} / \mathrm{Y}_{\mathrm{n}} \sim\right.$ 3). Only in Site 409 basalts is there some indication that some of the basalts have slightly lower $\mathrm{Ce} / \mathrm{Zr}$ ratios (Figure 25 ) than the rest of the group; but this could be analytical rather than real.

A plot of Y versus $\mathrm{Zr}$ for Reykjanes basalts (Figure 27) demonstrates that it is variations in $\mathrm{Y} / \mathrm{Zr}$ ratio which are controlling the variations in $\mathrm{Ce} / \mathrm{Y}$ ratio and thus the observed REE paterns. Each geochemical unit appears to have a different $\mathrm{Y} / \mathrm{Zr}$ ratio, but one which is constant within each unit and which has zero intercept. If $Y$ is behaving in a more compatible fashion during partial melting, then the observed relationships can be modeled as for Site 407 basalts (Figure 18). However, it is not possible to derive both Site 408 and Site 409 basalts from a source with a Y/Zr ratio similar to Site 407 . Figure 27 indicates that the Site 409 source has a higher $\mathrm{Y} / \mathrm{Zr}$ ratio and Site 408 a lower $\mathrm{Y} / \mathrm{Zr}$ 
TABLE 4-Continued

\begin{tabular}{lccccccccccc}
\hline Core-Section & $10-6$ & $10-7$ & $10-8$ & $11-1$ & $11-2$ & $11-3$ & $11-48$ & $12-1$ & $13-1$ & $13-3$ & $14-1$ \\
Interval $(\mathrm{cm})$ & $130-132$ & $4-6$ & $62-64$ & $61-63$ & $80-82$ & $80-82$ & $43-45$ & $141-143$ & $39-41$ & $40-42$ & $51-53$ \\
\multicolumn{1}{c}{ Piece } & 11 & 1 & 7 & 6 & 8 & 28 & $3 \mathrm{~A}$ & $15 \mathrm{~A}$ & 5 & 15 \\
\hline $\mathrm{SiO}_{2}$ & 49.54 & 49.89 & 48.68 & 48.91 & 50.28 & 49.71 & 49.76 & 49.52 & 48.81 & 47.33 & 47.09 \\
$\mathrm{TiO}_{2}$ & 1.28 & 1.34 & 1.34 & 1.26 & 1.15 & 1.14 & 1.23 & 1.14 & 1.13 & 1.74 & 1.76 \\
$\mathrm{Al}_{2} \mathrm{O}_{3}$ & 14.6 & 14.6 & 14.3 & 14.2 & 14.5 & 14.6 & 14.3 & 15.1 & 14.4 & 13.1 & 13.5 \\
$\mathrm{Fe}_{2} \mathrm{O}_{3}$ & 11.42 & 11.61 & 12.00 & 12.85 & 11.42 & 11.59 & 11.95 & 11.02 & 11.96 & 13.73 & 13.39 \\
$\mathrm{MnO}$ & 0.17 & 0.17 & 0.17 & 0.17 & 0.17 & 0.17 & 0.18 & 0.18 & 0.18 & 0.20 & 0.20 \\
$\mathrm{MgO}$ & 8.41 & 8.30 & 8.81 & 6.49 & 8.83 & 8.78 & 8.74 & 7.15 & 7.21 & 8.22 & 8.13 \\
$\mathrm{CaO}$ & 11.88 & 11.70 & 11.93 & 11.66 & 11.88 & 11.67 & 11.76 & 12.79 & 12.65 & 11.69 & 11.40 \\
$\mathrm{Na} 2 \mathrm{O}$ & 2.16 & 2.17 & 2.06 & 1.90 & 2.07 & 2.12 & 2.04 & 2.07 & 1.96 & 2.00 & 2.04 \\
$\mathrm{~K} 2 \mathrm{O}$ & 0.07 & 0.08 & 0.02 & 0.56 & 0.04 & 0.07 & 0.05 & 0.11 & 0.25 & 0.10 & 0.10 \\
$\mathrm{P}_{2} \mathrm{O}_{5}$ & 0.119 & 0.120 & 0.118 & 0.109 & 0.110 & 0.107 & 0.099 & 0.071 & 0.073 & 0.193 & 0.181 \\
$\mathrm{~T}$ & 99.7 & 99.9 & 100.4 & 98.2 & 100.5 & 99.9 & 100.1 & 99.1 & 98.6 & 98.3 & 97.8
\end{tabular}

\begin{tabular}{|c|c|c|c|c|c|c|c|c|c|c|c|}
\hline \multicolumn{12}{|c|}{ Trace elements in ppm } \\
\hline $\mathrm{Ni}$ & 76 & 77 & 82 & 84 & 78 & 75 & 76 & 102 & 94 & 96 & 107 \\
\hline $\mathrm{Cr}$ & 175 & 150 & 171 & 162 & 162 & 161 & 163 & 266 & 252 & 292 & 299 \\
\hline $\mathrm{Ga}$ & 18 & 17 & 19 & 17 & 17 & 18 & 18 & 18 & 16 & 20 & 20 \\
\hline $\mathrm{Rb}$ & 1 & $<1$ & $<1$ & 10 & -1 & 1 & 1 & 2 & 4 & 2 & 1 \\
\hline $\mathrm{Sr}$ & 85 & 85 & 85 & 82 & 85 & 83 & 81 & 94 & 97 & 100 & 100 \\
\hline Y & 24 & 24 & 26 & 23 & 24 & 23 & 23 & 25 & 24 & 36 & 34 \\
\hline $\mathrm{Zr}$ & 63 & 66 & 67 & 58 & 60 & 57 & 58 & 60 & 57 & 103 & 103 \\
\hline $\mathrm{Nb}$ & 6 & 7 & 8 & 8 & 7 & 6 & 8 & 7 & 6 & 11 & 14 \\
\hline $\mathrm{Ba}$ & 41 & 33 & 29 & 33 & 32 & 38 & 29 & 27 & 24 & 44 & 40 \\
\hline $\mathrm{La}$ & 4 & 5 & 4 & 4 & 5 & 3 & 5 & 4 & 3 & 9 & 8 \\
\hline $\mathrm{Ce}$ & 9 & 13 & 13 & 12 & 10 & 6 & 13 & 7 & 8 & 18 & 20 \\
\hline $\mathrm{Pb}$ & 3 & 5 & 5 & 2 & 3 & 2 & 3 & 3 & 3 & 1 & 3 \\
\hline Th & $<1$ & $<1$ & 1 & $<1$ & 2 & $<1$ & $<1$ & 1 & $<1$ & $<1$ & $<1$ \\
\hline $\mathrm{Zn}$ & 78 & 84 & 94 & 76 & 71 & 72 & 74 & 77 & 75 & 91 & 90 \\
\hline
\end{tabular}

\begin{tabular}{|c|c|c|c|c|c|c|c|c|c|c|c|}
\hline \multicolumn{12}{|c|}{ Selected element ratios } \\
\hline $\mathrm{K} / \mathrm{Rb}$ & 81.1 & - & - & 464.9 & 0.0 & 581.1 & 415.1 & 456.6 & 518.8 & 415.1 & 830.1 \\
\hline $\mathrm{Ri} / \mathrm{Sr}$ & 0.012 & & - & 0.12 & 0.000 & 0.012 & 0.12 & 0.021 & 0.041 & 0.020 & 0.010 \\
\hline $\mathrm{Ba} / \mathrm{Sr}$ & 0.48 & 0.39 & 0.34 & 0.40 & 0.38 & 0.46 & 0.36 & 0.29 & 0.25 & 0.44 & 0.40 \\
\hline $\mathrm{Zr} / \mathrm{Nb}$ & 10.5 & 9.4 & 8.4 & 7.2 & 8.6 & 9.5 & 7.2 & 8.6 & 9.5 & 9.4 & 7.4 \\
\hline $\mathrm{Zr} / \mathrm{Ce}$ & 7.0 & 5.1 & 5.2 & 4.8 & 6.0 & 9.5 & 4.5 & 8.6 & 7.1 & 5.7 & 5.2 \\
\hline $\mathrm{Zr} / \mathrm{Y}$ & 2.6 & 2.7 & 2.6 & 2.5 & 2.5 & 2.5 & 2.5 & 2.4 & 2.4 & 2.9 & 3.0 \\
\hline $\mathrm{Ce}_{\mathrm{N}} / \mathrm{Y}_{\mathrm{N}}$ & 0.92 & 1.32 & 1.22 & 1.27 & 1.02 & 0.64 & 1.38 & 0.68 & 0.81 & 1.22 & 1.44 \\
\hline $\mathrm{tFe} / \mathrm{Mg}$ & 1.6 & 1.6 & 1.6 & 2.3 & 1.5 & 1.5 & 1.6 & 1.8 & 1.9 & 1.9 & 1.9 \\
\hline \multicolumn{12}{|c|}{ C.I.P.W. Norm } \\
\hline Q & 0.0 & 0.0 & 0.0 & 0.4 & 0.0 & 0.0 & 0.0 & 0.0 & 0.0 & 0.0 & 0.0 \\
\hline Or & 0.4 & 0.5 & 0.1 & 3.4 & 0.2 & 0.4 & 0.3 & 0.7 & 1.5 & 0.6 & 0.6 \\
\hline $\mathrm{Ab}$ & 18.5 & 18.6 & 17.5 & 16.6 & 17.6 & 18.1 & 17.4 & 17.8 & 17.0 & 17.4 & 17.9 \\
\hline An & 30.4 & 30.0 & 29.9 & 29.6 & 30.4 & 30.4 & 30.1 & 32.0 & 30.5 & 27.3 & 28.4 \\
\hline $\mathrm{Ne}$ & 0.0 & 0.0 & 0.0 & 0.0 & 0.0 & 0.0 & 0.0 & 0.0 & 0.0 & 0.0 & 0.0 \\
\hline $\mathrm{Di}$ & 23.3 & 22.7 & 23.6 & 24.2 & 23.0 & 22.4 & 23.0 & 26.4 & 27.4 & 25.5 & 23.7 \\
\hline $\mathrm{Hy}$ & 19.6 & 21.9 & 21.0 & 20.8 & 23.0 & 20.8 & 22.3 & 18.5 & 16.6 & 16.4 & 16.7 \\
\hline OI & 2.9 & 1.3 & 2.9 & 0.0 & 1.3 & 3.4 & 2.2 & 0.2 & 2.4 & 6.4 & 6.4 \\
\hline Mt & 2.0 & 2.0 & 2.1 & 2.3 & 2.0 & 2.0 & 2.1 & 1.9 & 2.1 & 2.5 & 2.4 \\
\hline Il & 2.5 & 2.6 & 2.6 & 2.5 & 2.2 & 2.2 & 2.4 & 2.2 & 2.2 & 3.4 & 3.5 \\
\hline Ap & 0.3 & 0.3 & 0.3 & 0.3 & 0.3 & 0.3 & 0.2 & 0.2 & 0.1 & 0.5 & 0.4 \\
\hline
\end{tabular}

ratio than Site 407 . All the geochemical units (with the exception of Unit I in Site 407) must represent individual partial melt batches. Figure 27 also indicates that observed REE patterns in Reykjanes basalts may be a product of three factors: (a) a mantle source characteristic; (b) retention of HREE in the source during partial melting; and (c) differentiation in high-level magma chambers.

Titanium also shows a pattern of behavior similar to yttrium in the Reykjanes basalts (Figure 28), but it is certainly not identical. Sample points for individual geochemical units show an approximate linear correlation about a line passing through zero, but each unit has a slightly different $\mathrm{Ti} / \mathrm{Zr}$ ratio. This could indicate differences in the $\mathrm{Ti} / \mathrm{Zr}$ ratio in the mantle source, or that $\mathrm{Ti}$ is being retained in the mantle source with lower degrees of partial melting (or both). Those units with more transitional or alkaline affinities have lower $\mathrm{Ti} / \mathrm{Zr}$ ratios. Similarly, these units have lower $\mathrm{Y} / \mathrm{Zr}$ ratios (Figure 27). If these features are functions of partial melting, it would appear that $\mathrm{Y}$ is behaving in a more compatible fashion than $\mathrm{Ti}$, with the 
TABLE 4-Continued

\begin{tabular}{|c|c|c|c|c|c|c|c|c|c|c|c|}
\hline $\begin{array}{l}\text { Core-Section } \\
\text { Interval }(\mathrm{cm}) \\
\text { Piece } \\
\end{array}$ & $\begin{array}{c}15-1 \\
131-133 \\
16\end{array}$ & $\begin{array}{c}15-7 \\
36-38 \\
5\end{array}$ & $\begin{array}{c}15-3 \\
105-107 \\
9\end{array}$ & $\begin{array}{c}15-4 \\
64-66 \\
5 \mathrm{~A}\end{array}$ & $\begin{array}{c}15-5 \\
88-92 \\
11\end{array}$ & $\begin{array}{c}15-6 \\
55-59 \\
7\end{array}$ & $\begin{array}{c}16-1 \\
120-123 \\
-\end{array}$ & $\begin{array}{c}16-2 \\
15-18 \\
-\end{array}$ & $\begin{array}{c}17-1 \\
36-40 \\
5 \mathrm{~A}\end{array}$ & $\begin{array}{c}18-1 \\
74-78 \\
10\end{array}$ & $\begin{array}{c}18-2 \\
106-109 \\
11 \mathrm{~B} \\
\end{array}$ \\
\hline $\mathrm{SiO}_{2}$ & 45.91 & 45.78 & 48.18 & 47.92 & 46.73 & 48.44 & 48.10 & 44.66 & 46.47 & 45.47 & 48.43 \\
\hline $\mathrm{TiO}_{2}$ & 1.72 & 1.82 & 1.77 & 1.66 & 1.83 & 1.69 & 1.64 & 1.50 & 1.78 & 1.55 & 1.70 \\
\hline $\mathrm{Al}_{2} \mathrm{O}_{3}$ & 13.7 & 13.5 & 13.6 & 13.7 & 14.1 & 14.1 & 13.9 & 12.9 & 13.6 & 13.2 & 13.5 \\
\hline $\mathrm{Fe}_{2} \mathrm{O}_{3}$ & 12.73 & 13.25 & 13.05 & 13.14 & 12.50 & 12.92 & 12.89 & 11.02 & 13.75 & 12.16 & 12.59 \\
\hline $\mathrm{MnO}$ & 0.19 & 0.19 & 0.18 & 0.17 & 0.19 & 0.19 & 0.18 & 0.19 & 0.20 & 0.19 & 0.18 \\
\hline $\mathrm{MgO}$ & 5.97 & 5.86 & 7.86 & 6.72 & 5.79 & 7.05 & 6.93 & 6.43 & 7.45 & 6.36 & 8.63 \\
\hline $\mathrm{CaO}$ & 13.70 & 13.12 & 11.28 & 10.96 & 13.10 & 12.04 & 11.37 & 16.49 & 12.07 & 14.89 & 11.41 \\
\hline $\mathrm{Na}_{2} \mathrm{O}$ & 2.16 & 2.22 & 2.20 & 2.20 & 2.27 & 2.38 & 2.34 & 1.79 & 2.01 & 1.96 & 2.23 \\
\hline $\mathrm{K}_{2} \mathrm{O}$ & 0.27 & 0.31 & 0.24 & 0.46 & 0.27 & 0.25 & 0.30 & 0.21 & 0.14 & 0.29 & 0.24 \\
\hline $\mathrm{P}_{2} \mathrm{O}_{5}$ & 0.232 & 0.247 & 0.194 & 0.205 & 0.227 & 0.189 & 0.200 & 0.197 & 0.182 & 0.200 & 0.186 \\
\hline Total & 96.5 & 96.3 & 98.5 & 97.1 & 97.0 & 99.2 & 97.9 & 95.4 & 97.6 & 96.2 & 99.1 \\
\hline
\end{tabular}

Trace elements in ppm

$\begin{array}{lrrrrrrrrrrr}\mathrm{Ni} & 73 & 73 & 124 & 77 & 68 & 102 & 100 & 89 & 99 & 85 & 116 \\ \mathrm{Cr} & 237 & 227 & 292 & 263 & 233 & 309 & 285 & 247 & 258 & 269 & 284 \\ \mathrm{Ga} & 19 & 22 & 19 & 19 & 19 & 18 & 19 & 15 & 19 & 19 & 17 \\ \mathrm{Rb} & 3 & 4 & 2 & 6 & 3 & 3 & 4 & 3 & 2 & 5 & 2 \\ \mathrm{Sr} & 125 & 123 & 115 & 103 & 116 & 108 & 105 & 145 & 106 & 146 & 104 \\ \mathrm{Y} & 34 & 37 & 32 & 31 & 35 & 34 & 32 & 32 & 35 & 30 & 32 \\ \mathrm{Zr} & 104 & 109 & 101 & 95 & 106 & 9 & 98 & 99 & 105 & 96 & 99 \\ \mathrm{Nb} & 14 & 14 & 12 & 11 & 12 & 13 & 12 & 12 & 13 & 12 & 12 \\ \mathrm{Ba} & 60 & 69 & 60 & 68 & 66 & 62 & 60 & 52 & 40 & 52 & 57 \\ \mathrm{La} & 9 & 8 & 8 & 7 & 9 & 8 & 8 & 7 & 8 & 7 & 8 \\ \mathrm{Ce} & 20 & 23 & 18 & 15 & 21 & 19 & 20 & 15 & 21 & 18 & 17 \\ \mathrm{~Pb} & 6 & 3 & 3 & 3 & 3 & 3 & 5 & 2 & 2 & 4 & 2 \\ \mathrm{Th} & 2 & <1 & 1 & <1 & <1 & <1 & 1 & 1 & <1 & 1 & <1 \\ \mathrm{Zn} & 80 & 82 & 86 & 80 & 89 & 88 & 82 & 82 & 89 & 81 & 86\end{array}$

\begin{tabular}{|c|c|c|c|c|c|c|c|c|c|c|c|}
\hline \multicolumn{12}{|c|}{ Selected element ratios } \\
\hline $\mathrm{K} / \mathrm{Rb}$ & 747.1 & 643.3 & 996.1 & 636.4 & 747.1 & 691.8 & 622.6 & 581.1 & 581.1 & 481.5 & 996.1 \\
\hline $\mathrm{Rb} / \mathrm{Sr}$ & 0.024 & 0.033 & 0.017 & 0.058 & 0.026 & 0.028 & 0.038 & 0.021 & 0.019 & 0.034 & 0.019 \\
\hline $\mathrm{Ba} / \mathrm{Sr}$ & 0.48 & 0.56 & 0.52 & 0.66 & 0.57 & 0.57 & 0.57 & 0.36 & 0.38 & 0.36 & 0.55 \\
\hline $\mathrm{Zr} / \mathrm{Nb}$ & 7.4 & 7.8 & 8.4 & 8.6 & 8.8 & 7.6 & 8.2 & 8.2 & 8.1 & 8.0 & 8.2 \\
\hline $\mathrm{Zr} / \mathrm{Ce}$ & 5.2 & 4.7 & 5.6 & 6.3 & 5.0 & 5.2 & 4.9 & 6.6 & 5.0 & 5.3 & 5.8 \\
\hline $\mathrm{Zr} / \mathrm{Y}$ & 3.1 & 3.0 & 3.2 & 3.1 & 3.0 & 2.9 & 3.1 & 3.1 & 3.0 & 3.2 & 3.1 \\
\hline $\mathrm{Ce}_{\mathrm{N}} / \mathrm{Y}_{\mathrm{N}}$ & 1.44 & 1.52 & 1.37 & 1.18 & 1.47 & 1.37 & 1.53 & 1.15 & 1.47 & 1.47 & 1.30 \\
\hline $\mathrm{tFe} / \mathrm{Mg}$ & 2.5 & 2.6 & 1.9 & 2.3 & 2.5 & 2.1 & 2.1 & 2.0 & 2.1 & 2.2 & 1.7 \\
\hline \multicolumn{12}{|c|}{ C.I.P.W. Norm } \\
\hline Q & 0.0 & 0.0 & 0.0 & 0.0 & 0.0 & 0.0 & 0.0 & 010 & 0.0 & 0.0 & 0.0 \\
\hline Or & 1.7 & 1.9 & 1.5 & 2.8 & 1.7 & 1.5 & 1.8 & 1.3 & 0.9 & 1.8 & 1.4 \\
\hline $\mathrm{Ab}$ & 19.1 & 19.7 & 19.1 & 19.4 & 20.0 & 20.5 & 20.4 & 8.6 & 17.6 & 14.2 & 19.2 \\
\hline An & 28.0 & 27.3 & 27.1 & 27.4 & 28.7 & 27.6 & 27.5 & 28.1 & 28.6 & 27.6 & 26.7 \\
\hline $\mathrm{Ne}$ & 0.0 & 0.0 & 0.0 & 0.0 & 0.0 & 0.0 & 0.0 & 4.0 & 0.0 & 1.7 & 0.0 \\
\hline $\mathrm{Di}$ & 34.4 & 32.7 & 23.8 & 23.2 & 31.0 & 26.4 & 24.2 & 46.9 & 26.6 & 40.1 & 24.3 \\
\hline $\mathrm{Hy}$ & 0.3 & 1.8 & 17.6 & 19.1 & 5.4 & 11.8 & 15.6 & 0.0 & 11.8 & 0.0 & 15.1 \\
\hline $\mathrm{Ol}$ & 10.0 & 9.8 & 4.6 & 2.1 & 6.7 & 6.2 & 4.3 & 5.4 & 8.0 & 8.7 & 7.1 \\
\hline Mt & 2.3 & 2.4 & 2.3 & 2.4 & 2.3 & 2.3 & 2.3 & 2.0 & 2.5 & 2.2 & 2.2 \\
\hline Il & 3.4 & 3.6 & 3.5 & 3.3 & 3.6 & 3.3 & 3.2 & 3.0 & 3.5 & 3.1 & 3.3 \\
\hline Ap & 0.6 & 0.6 & 0.5 & 0.5 & 0.6 & 0.5 & 0.5 & 0.5 & 0.5 & 0.5 & 0.5 \\
\hline
\end{tabular}

result that there are small but significant differences in $\mathrm{Y} / \mathrm{Ti}$ ratio in the Reykjanes basalts (Figure 29).

In summary, there is a strong degree of geochemical coherence between basalts erupted at the Reykjanes Ridge over a period of more than $30 \mathrm{~m}$.y. Geochemical differences between Sites 407,408 , and 409 are certainly of no greater magnitude than those between the various units within Site 407. Ratios between many of the incompatible elements
$(\mathrm{Zr}, \mathrm{Nb}, \mathrm{Ba}, \mathrm{Ce}, \mathrm{La}, \mathrm{P})$ are essentially identical at all three sites, irrespective of the normative character of the basalts. Ratios between incompatible and more compatible elements (e.g., Ti/Zr, Y/Zr, Ce/Y) do vary, but this can be partly accounted for in terms of differing degrees of partial melting and differing depths of melting, with the more compatible elements being retained in the mantle source. These observations are very difficult to reconcile with hypotheses 
TABLE 4-Continued

\begin{tabular}{|c|c|c|c|c|c|c|c|c|c|c|c|}
\hline $\begin{array}{l}\text { Core-Section } \\
\text { Interval }(\mathrm{cm}) \\
\text { Piece }\end{array}$ & $\begin{array}{c}18-3 \\
88-91 \\
-\end{array}$ & $\begin{array}{c}20-11 \\
31-36 \\
-\end{array}$ & $\begin{array}{c}21-1 \\
83-86 \\
11\end{array}$ & $\begin{array}{c}21-7 \\
87-91 \\
10\end{array}$ & $\begin{array}{c}22-1 \\
90-93 \\
-\end{array}$ & $\begin{array}{c}23-1 \\
111-114 \\
12\end{array}$ & $\begin{array}{c}23-2 \\
38-41 \\
-\end{array}$ & $\begin{array}{c}24-1 \\
143-146 \\
15\end{array}$ & $\begin{array}{c}24-2 \\
87-90 \\
7\end{array}$ & $\begin{array}{c}24-3 \\
80-83 \\
7 \mathrm{~A} \\
\end{array}$ & $\begin{array}{c}24-4 \\
89-92 \\
7 \\
\end{array}$ \\
\hline $\mathrm{SiO}_{2}$ & 47.75 & 47.80 & 47.62 & 47.95 & 44.97 & 44.42 & 46.83 & 47.95 & 49.77 & 49.16 & 49.92 \\
\hline $\mathrm{TiO}_{2}$ & 1.69 & 1.70 & 1.78 & 1.73 & 1.59 & 1.58 & 1.81 & 1.69 & 1.69 & 1.66 & 1.64 \\
\hline $\mathrm{Al}_{2} \mathrm{O}_{3}$ & 13.6 & 13.3 & 13.8 & 13.3 & 12.9 & 12.6 & 13.5 & 13.1 & 14.2 & 14.2 & 14.1 \\
\hline $\mathrm{Fe}_{2} \mathrm{O}_{3}$ & 13.61 & 13.50 & 13.85 & 13.66 & 11.55 & 11.79 & 13.20 & 14.44 & 12.12 & 12.17 & 13.05 \\
\hline $\mathrm{MnO}$ & 0.19 & 0.20 & 0.20 & 0.19 & 0.18 & 0.18 & 0.20 & 0.21 & 0.17 & 0.17 & 0.18 \\
\hline $\mathrm{MgO}$ & 7.47 & 8.63 & 7.26 & 7.94 & 7.14 & 6.67 & 6.74 & 7.72 & 7.88 & 8.61 & 8.18 \\
\hline $\mathrm{CaO}$ & 11.53 & 11.88 & 11.97 & 12.02 & 15.66 & 16.16 & 12.56 & 11.66 & 11.31 & 11.38 & 11.49 \\
\hline $\mathrm{Na}_{2} \mathrm{O}$ & 2.10 & 2.03 & 2.04 & 2.02 & 1.84 & 1.84 & 2.17 & 2.68 & 2.28 & 2.13 & 2.13 \\
\hline $\mathrm{K}_{2} \mathrm{O}$ & 0.28 & 0.07 & 0.18 & 0.27 & 0.07 & 0.22 & 0.19 & 0.24 & 0.17 & 0.15 & 0.14 \\
\hline $\mathrm{P}_{2} \mathrm{O}_{5}$ & 0.184 & 0.195 & 0.202 & 0.171 & 0.186 & 0.222 & 0.201 & 0.170 & 0.240 & 0.191 & 0.196 \\
\hline Total & 98.4 & 99.3 & 98.9 & 99.3 & 96.1 & 95.7 & 97.4 & 99.8 & 99.8 & 99.8 & 101.0 \\
\hline \multicolumn{12}{|c|}{ Trace elements in ppm } \\
\hline $\mathrm{Ni}$ & 98 & 93 & 98 & 96 & 109 & 76 & 103 & 87 & 98 & 101 & 65 \\
\hline $\mathrm{Cr}$ & 282 & 300 & 269 & 280 & 242 & 216 & 231 & 287 & 330 & 306 & 196 \\
\hline $\mathrm{Ga}$ & 18 & 19 & 18 & 18 & 17 & 15 & 18 & 19 & 18 & 18 & 19 \\
\hline $\mathrm{Rb}$ & 5 & 1 & 4 & 5 & 1 & 4 & 2 & 3 & 3 & 3 & 2 \\
\hline $\mathrm{Sr}$ & 104 & 101 & 102 & 104 & 137 & 155 & 109 & 104 & 101 & 97 & 99 \\
\hline Y & 33 & 35 & 34 & 34 & 33 & 33 & 36 & 35 & 35 & 31 & 33 \\
\hline $\mathrm{Zr}$ & 99 & 103 & 106 & 105 & 98 & 99 & 107 & 103 & 110 & 92 & 99 \\
\hline $\mathrm{Nb}$ & 12 & 12 & 12 & 13 & 12 & 13 & 12 & 12 & 13 & 11 & 12 \\
\hline $\mathrm{Ba}$ & 37 & 58 & 40 & 44 & 33 & 50 & 37 & 61 & 70 & 61 & 31 \\
\hline $\mathrm{La}$ & 9 & 8 & 9 & 10 & 8 & 7 & 10 & 8 & 9 & 8 & 8 \\
\hline $\mathrm{Ce}$ & 20 & 21 & 23 & 18 & 19 & 15 & 21 & 16 & 19 & 14 & 20 \\
\hline $\mathrm{Pb}$ & 5 & 1 & 4 & 4 & 4 & 4 & 3 & 4 & 3 & 5 & 2 \\
\hline Th & 2 & 1 & 1 & $<1$ & 1 & 2 & $<1$ & 2 & 1 & $<1$ & 1 \\
\hline $\mathrm{Zn}$ & 89 & 90 & 89 & 91 & 86 & 88 & 94 & 82 & 87 & 86 & 87 \\
\hline \multicolumn{12}{|c|}{ Selected element ratios } \\
\hline $\mathrm{K} / \mathrm{Rb}$ & 464.9 & 581.1 & 373.5 & 448.3 & 581.1 & 456.6 & 788.6 & 664.1 & 470.4 & 415.0 & 581.1 \\
\hline $\mathrm{Rb} / \mathrm{Sr}$ & 0.048 & 0.010 & 0.039 & 0.048 & 0.007 & 0.026 & 0.018 & 0.029 & 0.030 & 0.031 & 0.02 \\
\hline $\mathrm{Ba} / \mathrm{Sr}$ & 0.36 & 0.57 & 0.39 & 0.42 & 0.24 & 0.32 & 0.34 & 0.59 & 0.69 & 0.63 & 0.31 \\
\hline $\mathrm{Zr} / \mathrm{Nb}$ & 8.2 & 8.6 & 8.8 & 8.1 & 8.2 & 7.6 & 8.9 & 8.6 & 8.5 & 8.4 & 8.2 \\
\hline $\mathrm{Zr} / \mathrm{Ce}$ & 5.0 & 4.9 & 4.6 & 5.8 & 5.2 & 6.6 & 5.1 & 6.4 & 5.8 & 6.6 & 5.0 \\
\hline $\mathrm{Zr} / \mathrm{Y}$ & 3.0 & 2.9 & 3.1 & 3.1 & 3.0 & 3.0 & 3.0 & 2.9 & 3.1 & 3.0 & 3.0 \\
\hline $\mathrm{Ce}_{\mathrm{N}} / \mathrm{Y}_{\mathrm{N}}$ & 1.48 & 1.47 & 1.65 & 1.29 & 1.41 & 1.11 & 1.43 & 1.12 & 1.33 & 1.10 & 1.48 \\
\hline $\mathrm{tFe} / \mathrm{Mg}$ & 2.1 & 1.8 & 2.2 & 2.0 & 1.9 & 2.0 & 2.3 & 2.2 & 1.8 & 1.6 & 1.9 \\
\hline \multicolumn{12}{|l|}{ C.I.P.W. Norm } \\
\hline Q & 0.0 & 0.0 & 0.0 & 0.0 & 0.0 & 0.0 & 0.0 & 0.0 & 0.0 & 0.0 & 0.0 \\
\hline Or & 1.7 & 0.4 & 1.1 & 1.6 & 0.4 & 1.4 & 1.2 & 1.4 & 1.0 & 0.9 & 0.8 \\
\hline $\mathrm{Ab}$ & 18.3 & 17.5 & 17.7 & 17.4 & 11.7 & 8.4 & 19.1 & 23.0 & 19.5 & 18.2 & 18.0 \\
\hline An & 27.6 & 27.5 & 28.6 & 27.0 & 28.1 & 26.9 & 27.6 & 23.3 & 28.3 & 29.0 & 28.4 \\
\hline $\mathrm{Ne}$ & 0.0 & 0.0 & 0.0 & 0.0 & 2.5 & 4.3 & 0.0 & 0.0 & 0.0 & 0.0 & 0.0 \\
\hline Di & 24.6 & 25.6 & 25.4 & 26.8 & 42.8 & 46.2 & 29.5 & 28.3 & 22.0 & 21.9 & 22.4 \\
\hline Hy & 16.2 & 15.4 & 15.9 & 14.4 & 0.0 & 0.0 & 9.2 & 3.5 & 22.9 & 20.9 & 23.4 \\
\hline $\mathrm{O} 1$ & 5.3 & 7.3 & 4.8 & 6.5 & 8.6 & 6.8 & 7.0 & 14.3 & 0.2 & 3.1 & 0.9 \\
\hline $\mathrm{Mt}$ & 2.4 & 2.4 & 2.5 & 2.4 & 2.1 & 2.2 & 2.4 & 2.5 & 2.1 & 2.1 & 2.3 \\
\hline Il & 3.3 & 3.3 & 3.5 & 3.4 & 3.2 & 3.2 & 3.6 & 3.2 & 3.2 & 3.2 & 3.1 \\
\hline Ap & 0.5 & 0.5 & 0.5 & 0.4 & 0.5 & 0.6 & 0.5 & 0.4 & 0.6 & 0.5 & 0.5 \\
\hline
\end{tabular}

of mixing of magmas or magma sources along the Reykjanes Ridge (e.g., Schilling, 1973, 1975b; Hart et al., 1973; Sun et al., 1975).

\section{SITE 410}

The area around the Mid-Atlantic Ridge at $45^{\circ} \mathrm{N}$ has been the subject of detailed investigation by the Canadian Hudson Geotraverse project (Aumento et al., 1971). Site 410 is west of the median valley at $45^{\circ} 30.51^{\prime} \mathrm{N}$, $29^{\circ} 28.56^{\prime} \mathrm{W}$ on anomaly 5 (about $10 \mathrm{~m}$.y.), in a water depth of 2957 meters. Hole 410 penetrated 47 meters of basalt breccia, grading down into basalt lava, before the core barrel became jammed. Hole 410A, 110 meters farther north, also penetrated about 41 meters of basalt before the drill string again jammed. The sediment cover in both holes is about 330 meters.

In Hole 410, the upper unit of 26 meters consists of a breccia of sparsely phyric basalt (olivine, plagioclase, and later, clinopyroxene) whereas the lower unit of 22 meters has up to 10 per cent of clinopyroxene, olivine, and 
TABLE 4-Continued

\begin{tabular}{|c|c|c|c|c|c|c|c|c|c|c|c|c|}
\hline $\begin{array}{c}\text { Core-Section } \\
\text { Interval }(\mathrm{cm}) \\
\text { Piece }\end{array}$ & $\begin{array}{c}24-4 \\
102-105 \\
11\end{array}$ & $\begin{array}{c}24-5 \\
69-72 \\
5 \mathrm{~B}\end{array}$ & $\begin{array}{c}24-5 \\
69-72 \\
5 \mathrm{~B}\end{array}$ & $\begin{array}{c}24-7 \\
56-59 \\
5\end{array}$ & $\begin{array}{c}25-1 \\
82-85 \\
6\end{array}$ & $\begin{array}{c}25-2 \\
35-38 \\
4 \mathrm{~A}\end{array}$ & $\begin{array}{c}25-3 \\
78-82 \\
9\end{array}$ & $\begin{array}{c}26-1 \\
29-32 \\
3\end{array}$ & $\begin{array}{c}28-1 \\
73-76 \\
9\end{array}$ & $\begin{array}{c}31-1 \\
121-124 \\
4 B\end{array}$ & $\begin{array}{c}31-2 \\
80-83 \\
-\end{array}$ & $\begin{array}{c}32-1 \\
135-138 \\
1 \mathrm{C} \\
\end{array}$ \\
\hline $\mathrm{SiO}_{2}$ & 48.18 & 48.14 & 48.23 & 49.71 & 48.06 & 47.36 & 48.07 & 48.04 & 44.74 & 48.71 & 48.22 & 48.59 \\
\hline $\mathrm{TiO}_{2}$ & 1.68 & 1.49 & 1.50 & 1.66 & 1.72 & 1.35 & 1.77 & 1.77 & 1.48 & 1.68 & 1.68 & 1.40 \\
\hline $\mathrm{Al}_{2} \mathrm{O}_{3}$ & 13.5 & 12.8 & 12.9 & 14.0 & 13.9 & 14.3 & 13.6 & 13.2 & 13.0 & 13.5 & 13.9 & 13.2 \\
\hline $\mathrm{Fe}_{2} \mathrm{O}_{3}$ & 13.15 & 15.61 & 15.65 & 12.12 & 12.57 & 12.11 & 13.40 & 13.61 & 10.78 & 13.39 & 13.54 & 13.48 \\
\hline $\mathrm{MnO}$ & 0.18 & 0.17 & 0.17 & 0.17 & 0.23 & 0.18 & 0.19 & 0.19 & 0.17 & 0.18 & 0.18 & 0.19 \\
\hline $\mathrm{MgO}$ & 7.63 & 6.51 & 6.57 & 9.23 & 7.55 & 8.46 & 6.78 & 7.79 & 6.30 & 7.70 & 7.34 & 8.77 \\
\hline $\mathrm{CaO}$ & 11.67 & 11.53 & 11.54 & 11.36 & 11.96 & 11.49 & 11.75 & 11.46 & 16.55 & 11.68 & 11.57 & 12.10 \\
\hline $\mathrm{Na}_{2} \mathrm{O}$ & 2.23 & 1.72 & 1.75 & 2.13 & 2.24 & 2.24 & 2.29 & 2.22 & 1.84 & 2.25 & 2.18 & 1.87 \\
\hline $\mathrm{K}_{2} \mathrm{O}$ & 0.21 & 0.78 & 0.80 & 0.17 & 0.29 & 0.24 & 0.27 & 0.24 & 0.19 & 0.24 & 0.32 & 0.14 \\
\hline $\mathrm{P}_{2} \mathrm{O}_{5}$ & 0.170 & 0.151 & 0.157 & 0.196 & 0.205 & 0.184 & 0.195 & 0.189 & 0.190 & 0.167 & 0.168 & 0.119 \\
\hline Total & 98.6 & 98.9 & 99.2 & 100.7 & 98.8 & 98.0 & 98.3 & 98.7 & 95.2 & 99.5 & 99.1 & 99.8 \\
\hline
\end{tabular}

\section{Trace elements in ppm}

$\begin{array}{lrrrrrrrrrrrr}\mathrm{Ni} & 108 & 87 & 88 & 98 & 110 & 144 & 79 & 93 & 94 & 110 & 97 & 94 \\ \mathrm{Cr} & 273 & 275 & 270 & 278 & 265 & 323 & 272 & 250 & 227 & 262 & 263 & 287 \\ \mathrm{Ga} & 17 & 16 & 16 & 19 & 29 & 19 & 17 & 19 & 16 & 18 & 18 & 20 \\ \mathrm{Rb} & 3 & 15 & 15 & 3 & 4 & 3 & 3 & 2 & 2 & 3 & 5 \\ \mathrm{Sr} & 103 & 242 & 244 & 99 & 106 & 103 & 146 & 102 & 148 & 101 & 99 \\ \mathrm{Y} & 34 & 29 & 28 & 33 & 33 & 28 & 34 & 35 & 30 & 34 & 32 & 30 \\ \mathrm{Zr} & 99 & 87 & 88 & 101 & 97 & 89 & 104 & 106 & 96 & 100 & 100 & 78 \\ \mathrm{Nb} & 11 & 12 & 11 & 13 & 12 & 12 & 12 & 14 & 12 & 12 & 12 & 9 \\ \mathrm{Ba} & 40 & 55 & 54 & 48 & 59 & 48 & 40 & 50 & 35 & 23 & 22 & 19 \\ \mathrm{La} & 7 & 7 & 7 & 7 & 8 & 7 & 8 & 9 & 7 & 8 & 8 & 6 \\ \mathrm{Ce} & 18 & 17 & 16 & 20 & 17 & 16 & 20 & 21 & 16 & 20 & 19 & 14 \\ \mathrm{~Pb} & 2 & 5 & 4 & 3 & 3 & 3 & 3 & 2 & 3 & 3 & 3 & 4 \\ \mathrm{Th} & 1 & 1 & 2 & 3 & <1 & 2 & <1 & <1 & <1 & 1 & 1 \\ \mathrm{Zn} & 88 & 90 & 91 & 88 & 86 & 78 & 85 & 94 & 87 & 90 & 88 & 85\end{array}$

Selected element ratios

$\begin{array}{lcccccccccccc}\mathrm{K} / \mathrm{Rb} & 581.1 & 431.7 & 442.7 & 470.4 & 601.8 & 664.1 & 747.1 & 996.1 & 788.6 & 664.1 & 531.3 & 387.4 \\ \mathrm{Rb} / \mathrm{Sr} & 0.029 & 0.061 & 0.061 & 0.030 & 0.038 & 0.029 & 0.021 & 0.020 & 0.014 & 0.030 & 0.051 & 0.033 \\ \mathrm{Ba} / \mathrm{Sr} & 0.39 & 0.23 & 0.22 & 0.48 & 0.56 & 0.47 & 0.27 & 0.49 & 0.24 & 0.23 & 0.22 & 0.21 \\ \mathrm{Zr} / \mathrm{Nb} & 9.0 & 7.2 & 8.0 & 7.8 & 8.1 & 7.4 & 8.7 & 7.6 & 8.0 & 8.3 & 8.3 & 8.7 \\ \mathrm{Zr} / \mathrm{Ce} & 5.5 & 5.1 & 5.5 & 5.0 & 5.7 & 5.6 & 5.2 & 5.0 & 6.0 & 5.0 & 5.3 & 5.6 \\ \mathrm{Zr} / \mathrm{Y} & 2.9 & 3.0 & 3.1 & 3.1 & 2.9 & 3.2 & 3.1 & 3.0 & 3.2 & 2.9 & 3.1 & 2.6 \\ \mathrm{Ce} / \mathrm{Y} & 1.29 & 1.43 & 1.40 & 1.48 & 1.26 & 1.40 & 1.44 & 1.47 & 1.30 & 1.44 & 1.45 & 1.14 \\ \mathrm{tFe} / \mathrm{Mg} & 2.0 & 2.8 & 2.8 & 1.5 & 1.9 & 1.6 & 2.3 & 2.0 & 2.0 & 2.0 & 2.1 & 1.8\end{array}$

\section{C.I.P.W. Norm}

\begin{tabular}{|c|c|c|c|c|c|c|c|c|c|c|c|c|}
\hline $\mathrm{Q}$ & 0.0 & 0.0 & 0.0 & 0.0 & 0.0 & 0.0 & 0.0 & 0.0 & 0.0 & 0.0 & 0.0 & 0.0 \\
\hline Or & 1.3 & 4.7 & 4.8 & 1.0 & 1.7 & 1.5 & 1.6 & 1.4 & 1.2 & 1.4 & 1.9 & 0.8 \\
\hline $\mathrm{Ab}$ & 19.4 & 14.9 & 15.1 & 18.1 & 19.4 & 19.5 & 19.9 & 19.2 & 8.8 & 19.3 & 18.8 & 15.9 \\
\hline An & 26.8 & 25.6 & 25.4 & 28.2 & 27.7 & 29.3 & 26.7 & 26.0 & 28.2 & 26.6 & 27.8 & 17.6 \\
\hline $\mathrm{Ne}$ & 0.0 & 0.0 & 0.0 & 0.0 & 0.0 & 0.0 & 0.0 & 0.0 & 4.2 & 0.0 & 0.0 & 0.0 \\
\hline Di & 25.9 & 26.6 & 26.7 & 22.0 & 26.0 & 23.1 & 26.4 & 25.5 & 47.2 & 25.7 & 24.4 & 26.6 \\
\hline $\mathrm{Hy}$ & 15.3 & 19.8 & 18.9 & 21.1 & 12.4 & 10.1 & 14.9 & 15.4 & 0.0 & 15.8 & 15.4 & 18.5 \\
\hline $\mathrm{Ol}$ & 5.3 & 2.2 & 2.9 & 3.8 & 6.6 & 11.1 & 4.0 & 6.0 & 4.9 & 5.2 & 5.4 & 5.2 \\
\hline Mt & 2.4 & 2.8 & 2.8 & 2.1 & 2.2 & 2.2 & 2.4 & 2.4 & 2.0 & 2.4 & 2.4 & 2.4 \\
\hline Il & 3.3 & 2.9 & 2.9 & 3.2 & 3.3 & 2.6 & 3.5 & 3.4 & 3.0 & 3.2 & 3.3 & 2.7 \\
\hline Ap & 0.4 & 0.4 & 0.4 & 0.5 & 0.5 & 0.5 & 0.5 & 0.5 & 0.5 & 0.4 & 0.4 & 0.3 \\
\hline
\end{tabular}

plagioclase phenocrysts. These two units are clearly distinguished by their chemistry (Table 5), although only three samples were analyzed. The rocks from both units are relatively unaltered.

The basalts in Hole 410A are rather uniform (Table 6), and have minor olivine (1\%) and later plagioclase phenocrysts. The rocks again are fresh and the olivines well preserved.
Site 410 basalts (Table 5) are clearly part of a coherent geochemical group, and have trace-element characteristics very different from those recovered at the sites of the Reykjanes transect. Nevertheless, there is a surprisingly large range of composition within the relatively short section of lavas cored in the two closely separated holes. There are two geochemical units in Hole 410A. The upper one, in Core 2, appears to correspond to the uppermost unit 


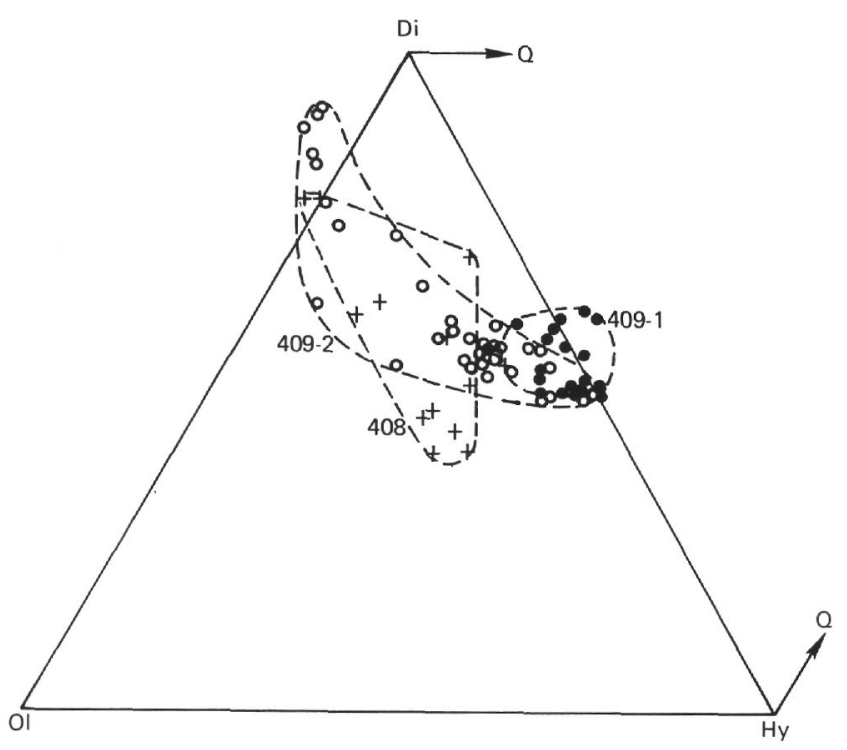

Figure 20. Normative compositions of basalts from Sites 408 and 409 plotted in the system Olivine-DiopsideHypersthene (-Quartz-Nepheline). Fields indicate different geochemical units.

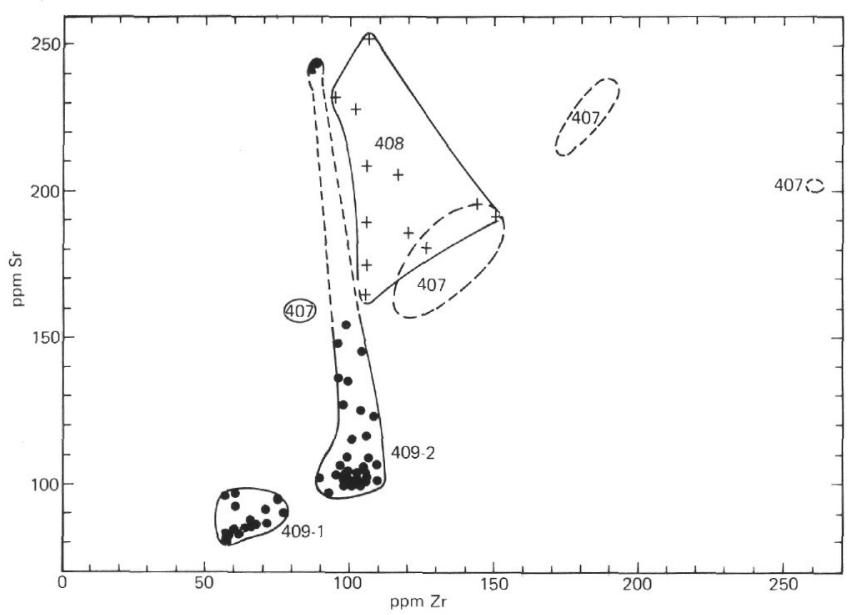

Figure 21. Sr versus $\mathrm{Zr}$ for basalts from Sites 408 and 409. Enclosed points indicate different geochemical units. Fields for Site 407 basalts shown for comparison.

(Core 37) in Hole 410, but the lower unit in Hole 410 is much more fractionated than the lower unit in Hole 410A (Tables 5 and 6). Such wide variations between adjacent holes are by no means uncommon in deep-sea drilling (cf. Leg 37).

Site 410 basalts are all olivine-normative, and all are poor in normative hypersthene (Figure 29); indeed, several from Hole 410A have minor quantities of normative nepheline, and the two more fractionated samples from Hole 410 have appreciable normative nepheline. Though minor alteration and the assumptions regarding $\mathrm{Fe}^{2+} / \mathrm{Fe}^{3+}$ ratios can quite easily produce minor proportions of nepheline in the calculated norm, the lower unit of Hole 410 does seem to have definite alkaline affinities, in that $\mathrm{K}, \mathrm{Rb}, \mathrm{Ba}, \mathrm{Sr}, \mathrm{P}$, and $\mathrm{Nb}$ are all very high. Such high values could perhaps be

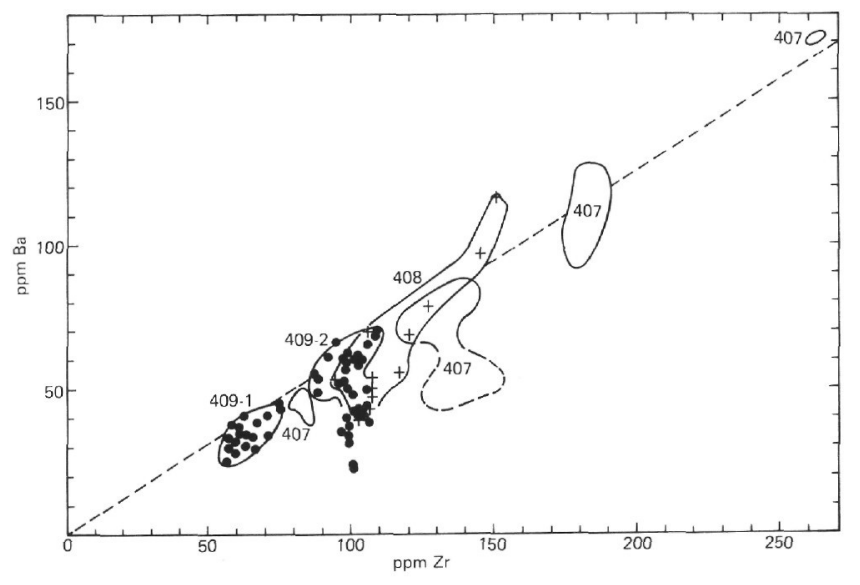

Figure 22. Ba versus $Z$ r for basalts from Sites 408 and 409. Correlation line and fields for Site 407 basalts shown for comparison.

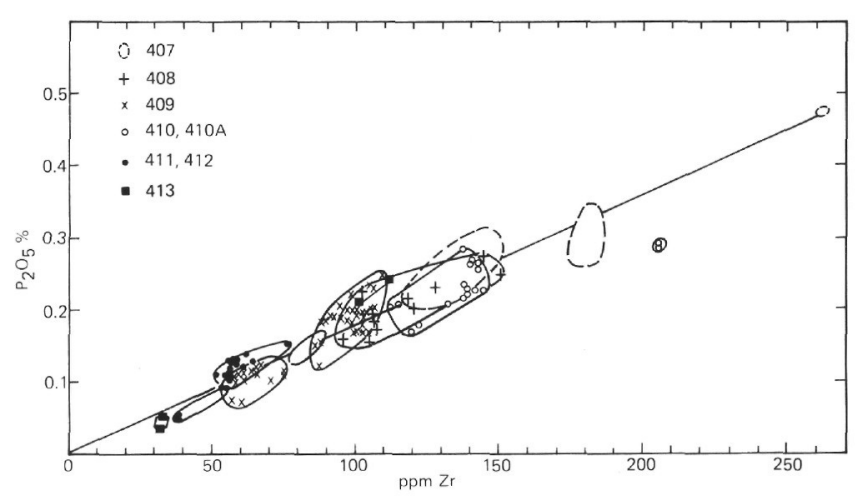

Figure 23. $\mathrm{P}_{2} \mathrm{O}_{5}$ versus $\mathrm{Zr}$ for Leg 49 basalts. Fields are shown only for Site 407 basalts (see Figure 15).

attained by extreme differentiation of ocean ridge basalts, but although the Fe/Mg ratios of this unit are indeed high, it should be noted that the levels of $\mathrm{Cr}$ and $\mathrm{Ni}$ are high also, and silica is still low. Moreover, Ce/Y ratios are also high, a typical characteristic of alkalic basalts. It may be concluded that the basalts at Site 410 have transitional to alkaline characteristics. In this respect they are similar to basalts near the median valley at $45^{\circ} \mathrm{N}$ (Muir and Tilley, 1964; Aumento, 1968; Erlank and Kable, 1976), although apparently some $10 \mathrm{~m} . \mathrm{y}$. older.

The relationships between Site 410 basalts may be explored using zirconium as a differentiation index. As emphasized by Weaver et al. (1972), zirconium appears to behave just as incompatibly in alkalic basalt suites as in tholeiites. Normalizing geochemical relationships in this way also allows a direct comparison with basalts from Sites 407, 408, and 409 of the Reykjanes transect. In many cases, to aid in this comparison, the fields for the various geochemical units of the Reykjanes sites are included on the diagrams, as are the geochemical units from sites of the FAMOUS area.

In general, most incompatible elements show good correlations with zirconium. Barium, for instance (Figure 30 ), increases markedly with increasing $\mathrm{Zr}$, and reaches 450 


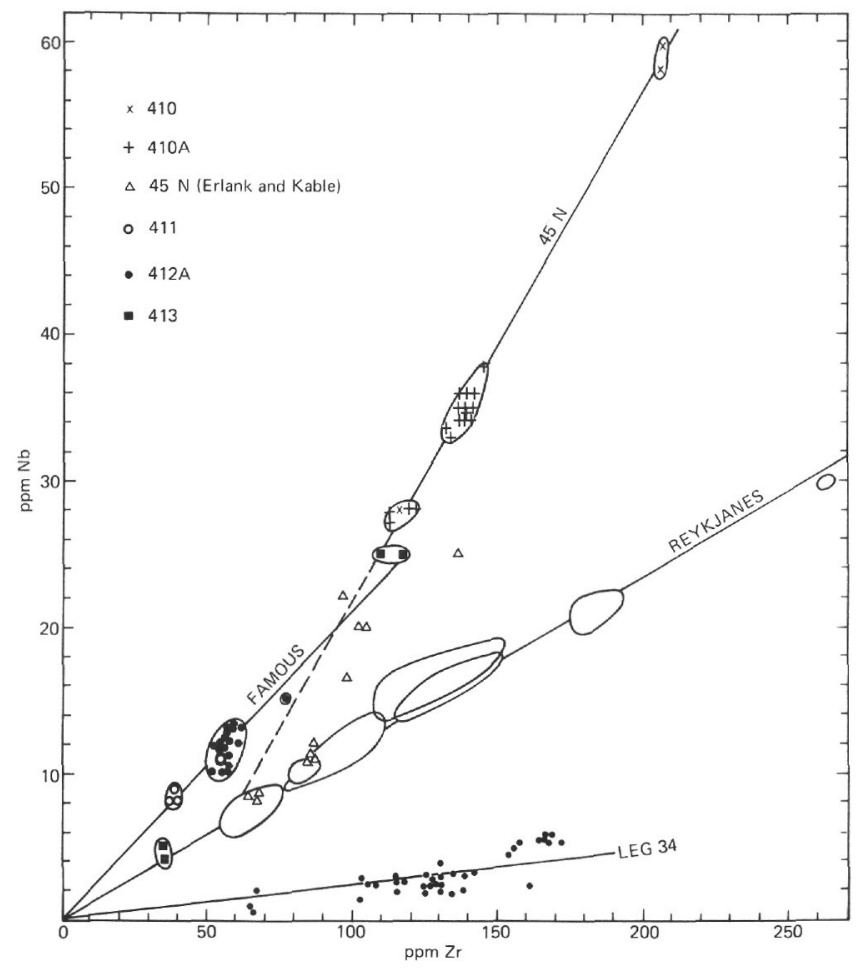

Figure 24. $\mathrm{Nb}$ versus $\mathrm{Zr}$ for basalts from $45^{\circ} \mathrm{N}$ and $\mathrm{FA}$ MOUS sites. Data points for the median valley at $45^{\circ} \mathrm{N}$ from Erlank and Kable (1976) and for Nazca plate basalts (Leg 34) from Cann and Heath (1976) and Rhodes et al. (1976). Fields for Reykjanes basalts shown for comparison, together with data points for basalts from eastern Iceland.

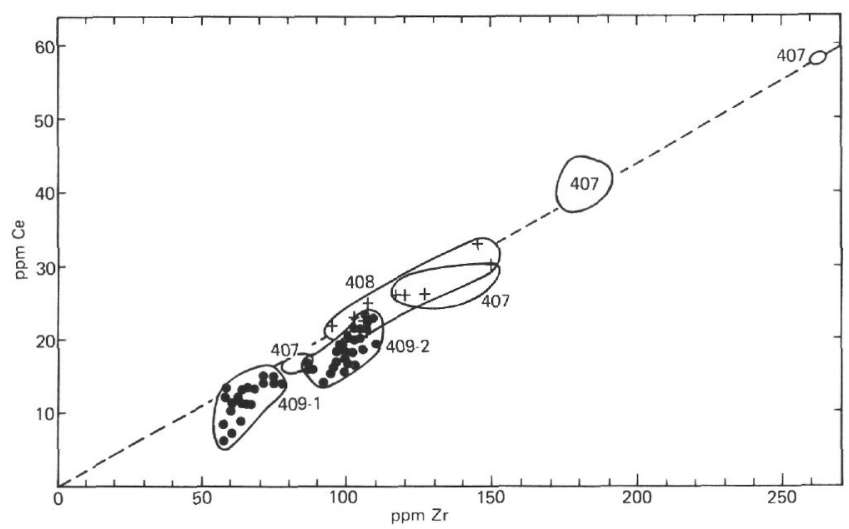

Figure 25. Ce versus $Z r$ for basalts from Sites 408 and 409 . Fields indicate different geochemical units. Correlation line and fields for Site 407 basalts shown for comparison.

ppm in the most fractionated lavas from Hole 410. Although this relationship may be linear, the extended correlation line does not go through the origin. This could indicate that $\mathrm{Ba}$ is behaving more incompatibly than $\mathrm{Zr}$ at low degrees of partial melting, and that at higher degrees of melting (than

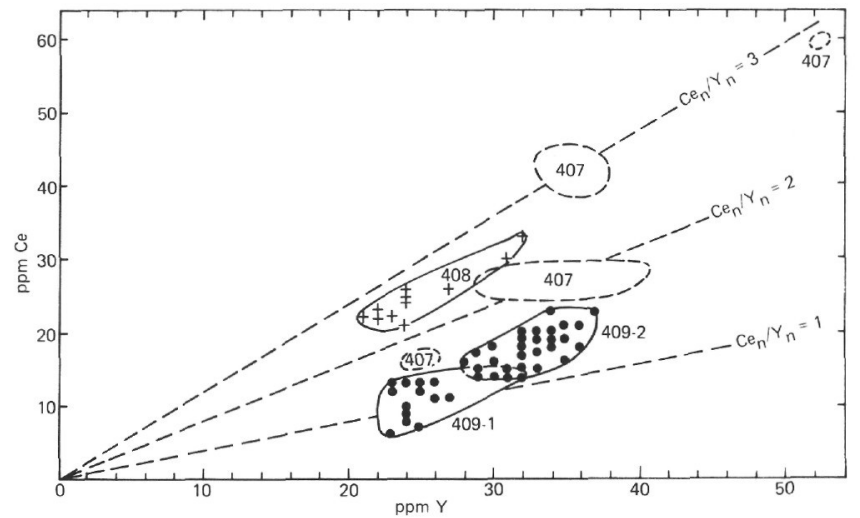

Figure 26. Ce versus $Y$ for basalts from Sites 408 and 409. Lines indicate chondrite-normalized $\mathrm{Ce} / Y$ ratio values. Fields for Site 407 basalts shown for comparison.

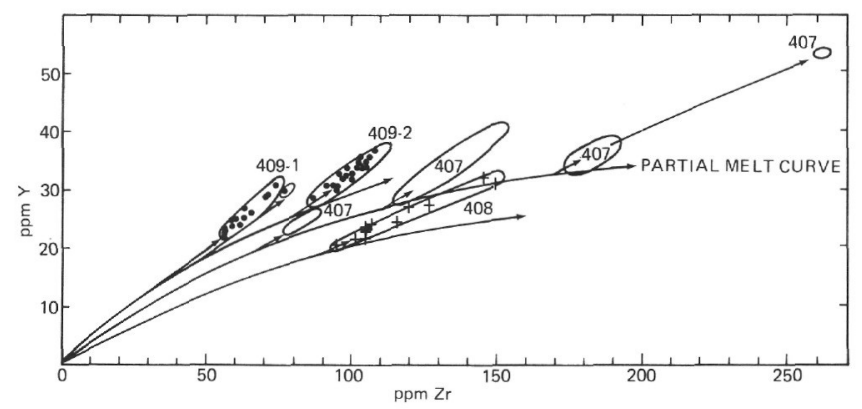

Figure 27. $Y$ versus $Z r$ plot for Site 408 and Site 409 basalts. Fields for Site 407 basalts also shown, together with a possible partial melting/fractional crystallization model (based on Figure 18) relating the different geochemical units at the three sites.

observed here) the line may curve toward the origin. Note that $\mathrm{Ba} / \mathrm{Zr}$ ratios are much higher than in the Reykjanes samples, a feature noted previously by Erlank and Kable (1976) in axial dredged samples from $45^{\circ} \mathrm{N}$. Both $\mathrm{K}_{2} \mathrm{O}$ and $\mathrm{Rb}$ are also unusually high in Site 410 basalts; $\mathrm{K}_{2} \mathrm{O}$ reaches 0.5 per cent in the main group of lavas and over 1.5 per cent in the most fractionated samples. The latter samples have 30 ppm $\mathrm{Rb}$. In both cases the line correlating with $\mathrm{Zr}$ does not pass through the origin. The rather fresh nature of Site 410 basalts and the close clustering of points would seem to indicate that the measured values of $\mathrm{K}$ and $\mathrm{Rb}$ might be primary, in which case they seem, like $\mathrm{Ba}$, to be acting much more incompatibly than $\mathrm{Zr}$ at low degrees of partial melting.

Niobium shows a particularly good linear correlation with $\mathrm{Zr}$ (Figure 24), but unlike the Reykjanes samples, the line does not pass through the origin. $\mathrm{Zr} / \mathrm{Nb}$ ratios are significantly lower than in the Reykjanes basalts, but the mean value is a little lower than that found by Erlank and Kable (1976) for dredged basalts from $45^{\circ} \mathrm{N}$. The data of Erlank and Kable do in fact plot very near the correlation line, and confirm that this line intercepts the $\mathrm{Zr}$ axis. It 


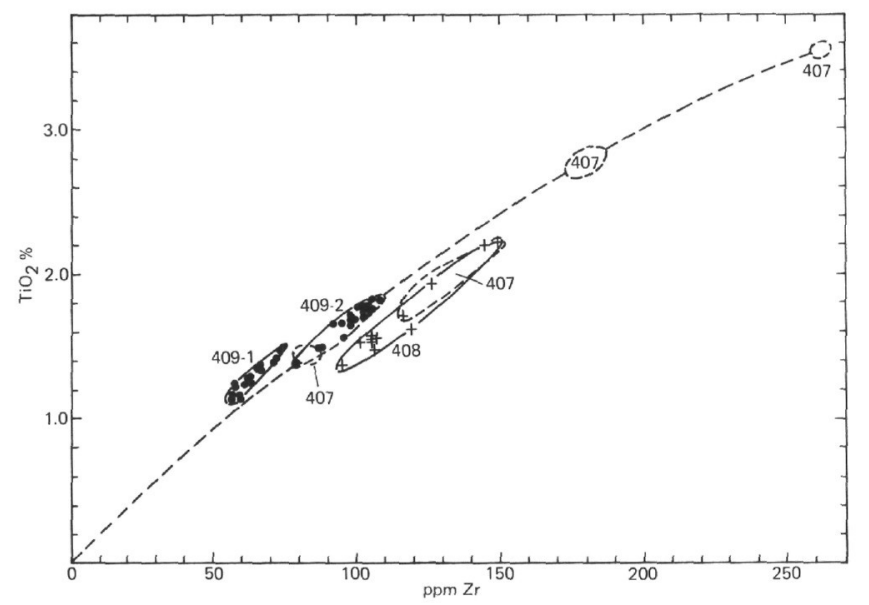

Figure 28. $\mathrm{TiO}_{2}$ versus $\mathrm{Zr}$ for basalts from Sites 408 and 409. Enclosed points indicate different geochemical units. Correlation line and fields for Site 407 basalts shown for comparison.

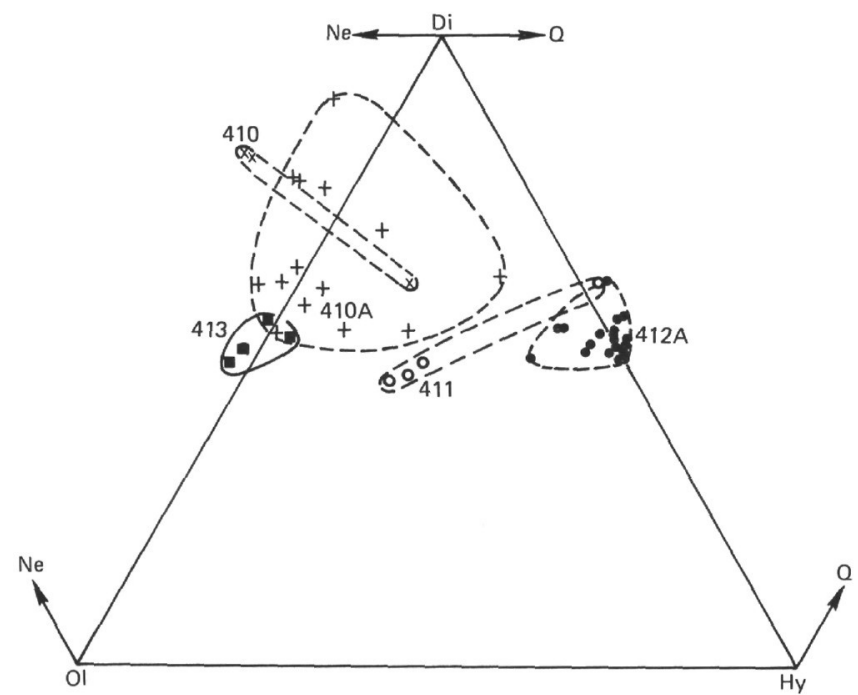

Figure 29. Normative compositions of basalts from $45^{\circ} \mathrm{N}$ and FAMOUS sites plotted in the system Olivine-Diopside-Hypersthene (-Quartz-Nepheline). Fields indicate different holes.

would appear that low $\mathrm{Zr} / \mathrm{Nb}$ ratios characterize basalts erupted along this segment of the Mid-Atlantic Ridge for at least $10 \mathrm{~m}$.y. This supports the conclusion, suggested by the Reykjanes transect data, that basalt $\mathrm{Zr} / \mathrm{Nb}$ ratios reflect their mantle source; a source, moreover, that must be fairly uniform with regard to $\mathrm{Zr} / \mathrm{Nb}$, and which also must be of considerable volume.

Strontium also shows a good correlation with $\mathrm{Zr}$ (Figure 31 ), but as with $\mathrm{Nb}$ and $\mathrm{Ba}$, the line does not pass through zero. It is clear from this plot that $\mathrm{Sr}$ levels and $\mathrm{Sr} / \mathrm{Zr}$ ratios are higher than in the Reykjanes basalts. Strontium is
TABLE 5

Analyses of Basalts From Hole 410, Leg 49

\begin{tabular}{|c|c|c|c|}
\hline $\begin{array}{l}\text { Core-Section } \\
\text { Interval }(\mathrm{cm}) \\
\text { Piece }\end{array}$ & $\begin{array}{c}37-1 \\
100-110 \\
10+11\end{array}$ & $\begin{array}{c}39-3 \\
100-105 \\
7\end{array}$ & $\begin{array}{c}39-4 \\
110-114 \\
9 \mathrm{~A}\end{array}$ \\
\hline $\mathrm{SiO}_{2}$ & 50.40 & 49.91 & 49.56 \\
\hline $\mathrm{TiO}_{2}$ & 1.45 & 1.38 & 1.30 \\
\hline $\mathrm{Al}_{2} \mathrm{O}_{3}$ & 16.0 & 16.5 & 16.5 \\
\hline $\mathrm{Fe}_{2} \mathrm{O}_{3}$ & 9.80 & 8.87 & 8.77 \\
\hline $\mathrm{MnO}$ & 0.16 & 0.17 & 0.16 \\
\hline $\mathrm{MgO}$ & 6.89 & 4.45 & 4.46 \\
\hline $\mathrm{CaO}$ & 11.28 & 10.11 & 10.31 \\
\hline $\mathrm{Na}_{2} \mathrm{O}$ & 3.14 & 4.43 & 4.16 \\
\hline $\mathrm{K}_{2} \mathrm{O}$ & 0.57 & 1.69 & 1.70 \\
\hline $\mathrm{P}_{2} \mathrm{O}_{5}$ & 0.209 & 0.293 & 0.286 \\
\hline Total & 99.9 & 97.8 & 97.2 \\
\hline
\end{tabular}

Trace elements in ppm

$\begin{array}{lrrr}\mathrm{Ni} & 86 & 95 & 108 \\ \mathrm{Cr} & 189 & 238 & 289 \\ \mathrm{Ga} & 17 & 23 & 23 \\ \mathrm{Rb} & 7 & 32 & 33 \\ \mathrm{Sr} & 226 & 463 & 470 \\ \mathrm{Y} & 24 & 25 & 23 \\ \mathrm{Zr} & 115 & 207 & 206 \\ \mathrm{Nb} & 28 & 60 & 58 \\ \mathrm{Ba} & 172 & 465 & 447 \\ \mathrm{La} & 16 & 37 & 36 \\ \mathrm{Ce} & 35 & 64 & 64 \\ \mathrm{~Pb} & 3 & 6 & 7 \\ \mathrm{Th} & 2 & 5 & 7 \\ \mathrm{Zn} & 69 & 76 & 72\end{array}$

Selected element ratios

$\begin{array}{lccc}\mathrm{K} / \mathrm{Rb} & 675.9 & 438.4 & 427.6 \\ \mathrm{Rb} / \mathrm{Sr} & 0.031 & 0.069 & 0.070 \\ \mathrm{Ba} / \mathrm{Sr} & 0.76 & 1.00 & 0.95 \\ \mathrm{Zr} / \mathrm{Nb} & 4.1 & 3.5 & 3.6 \\ \mathrm{Zr} / \mathrm{Ce} & 3.3 & 3.2 & 3.2 \\ \mathrm{Zr} / \mathrm{Y} & 4.8 & 8.3 & 9.0 \\ \mathrm{Ce} / \mathrm{Y} & 3.56 & 6.26 & 6.80 \\ \mathrm{tFe} / \mathrm{Mg} & 1.6 & 2.3 & 2.3\end{array}$

$\begin{array}{lrrr}\text { C.I.P.W. Norm } & & & \\ \mathrm{Q} & 0.0 & 0.0 & 0.0 \\ \mathrm{Or} & 3.4 & 10.3 & 10.4 \\ \mathrm{Ab} & 26.8 & 25.7 & 24.9 \\ \mathrm{An} & 28.1 & 20.7 & 22.2 \\ \mathrm{Ne} & 0.0 & 7.0 & 6.3 \\ \mathrm{Di} & 22.1 & 23.9 & 24.0 \\ \mathrm{Hy} & 5.7 & 0.0 & 0.0 \\ \mathrm{Al} & 8.8 & 7.3 & 7.4 \\ \mathrm{Mt} & 1.7 & 1.6 & 1.6 \\ \mathrm{Ol} & 2.8 & 2.7 & 2.6 \\ \mathrm{Ap} & 0.5 & 0.7 & 0.7\end{array}$

behaving in a much more incompatible fashion than in the Reykjanes basalts. This linear correlation with $\mathrm{Zr}$ also provides important constraints on the relationships between 
TABLE 6

Analyses of Basalts From Hole 410A, Leg 49

\begin{tabular}{|c|c|c|c|c|c|c|c|c|c|c|c|c|c|c|c|}
\hline $\begin{array}{c}\text { Core-Section } \\
\text { Interval }(\mathrm{cm}) \\
\text { Piece }\end{array}$ & $\begin{array}{c}2-1 \\
48-52 \\
7\end{array}$ & $\begin{array}{c}2-3 \\
43-45 \\
4\end{array}$ & $\begin{array}{c}2-5 \\
97-100 \\
13\end{array}$ & $\begin{array}{c}3-2 \\
111-119 \\
14\end{array}$ & $\begin{array}{c}3-4 \\
120-123 \\
-\end{array}$ & $\begin{array}{c}3-5 \\
33-38 \\
5 B\end{array}$ & $\begin{array}{c}4-3 \\
- \\
18\end{array}$ & $\begin{array}{c}4-4 \\
65-70 \\
7 \mathrm{~A}\end{array}$ & $\begin{array}{c}5-1 \\
57-59 \\
9\end{array}$ & $\begin{array}{c}5-2 \\
105-119 \\
14\end{array}$ & $\begin{array}{c}5-4 \\
95-106 \\
12\end{array}$ & $\begin{array}{c}6-1 \\
8-16 \\
2 \mathrm{~A}\end{array}$ & $\begin{array}{c}6-1 \\
118-126 \\
17\end{array}$ & $\begin{array}{c}6-2 \\
122-132 \\
17\end{array}$ & $\begin{array}{c}6-3 \\
2-8 \\
1\end{array}$ \\
\hline $\mathrm{SiO}_{2}$ & 50.27 & 48.59 & 49.65 & 48.05 & 48.43 & 47.93 & 46.27 & 48.04 & 48.42 & 49.09 & 47.97 & 45.47 & 47.88 & 47.07 & 46.84 \\
\hline $\mathrm{TiO}_{2}$ & 1.38 & 1.43 & 1.40 & 1.45 & 1.39 & 1.43 & 1.38 & 1.35 & 1.43 & 1.44 & 1.34 & 1.29 & 1.49 & 1.40 & 1.43 \\
\hline $\mathrm{Al}_{2} \mathrm{O}_{3}$ & 14.6 & 14.7 & 13.9 & 13.5 & 14.0 & 14.1 & 13.7 & 13.4 & 13.7 & 13.6 & 14.7 & 13.7 & 14.6 & 14.6 & 14.9 \\
\hline $\mathrm{Fe}_{2} \mathrm{O}_{3}$ & 9.41 & 9.66 & 9.38 & 9.45 & 9.35 & 9.16 & 8.97 & 8.60 & 9.11 & 9.13 & 8.70 & 8.22 & 9.17 & 8.82 & 9.30 \\
\hline $\mathrm{MnO}$ & 0.16 & 0.16 & 0.13 & 0.14 & 0.13 & 0.13 & 0.14 & 0.12 & 0.14 & 0.13 & 0.15 & 0.13 & 0.16 & 0.15 & 0.16 \\
\hline $\mathrm{MgO}$ & 7.24 & 6.89 & 10.01 & 11.39 & 10.39 & 10.37 & 11.89 & 12.44 & 10.30 & 10.33 & 7.25 & 6.77 & 7.41 & 7.31 & 6.83 \\
\hline $\mathrm{CaO}$ & 11.46 & 12.54 & 10.72 & 11.18 & 11.22 & 11.60 & 12.06 & 11.03 & 11.93 & 11.43 & 12.13 & 15.05 & 12.50 & 12.78 & 12.53 \\
\hline $\mathrm{Na}_{2} \mathrm{O}$ & 2.77 & 3.01 & 2.82 & 2.44 & 2.78 & 2.78 & 2.41 & 2.57 & 2.77 & 2.85 & 2.49 & 2.24 & 3.27 & 2.77 & 3.06 \\
\hline $\mathrm{K}_{2} \mathrm{O}$ & 0.64 & 0.39 & 0.44 & 0.37 & 0.41 & 0.42 & 0.43 & 0.46 & 0.39 & 0.41 & 0.80 & 0.70 & 0.62 & 0.59 & 0.54 \\
\hline $\mathrm{P}_{2} \mathrm{O}_{5}$ & 0.168 & 0.180 & 0.205 & 0.222 & 0.236 & 0.235 & 0.221 & 0.263 & 0.256 & 0.226 & 0.212 & 0.206 & 0.261 & 0.262 & 0.303 \\
\hline Total & 98.1 & 97.5 & 98.6 & 98.2 & 98.4 & 98.1 & 97.5 & 98.3 & 98.4 & 98.7 & 95.8 & 93.8 & 87.4 & 95.7 & 95.9 \\
\hline
\end{tabular}

$\begin{array}{lr}\text { Trace elements in } & \text { ppm } \\ \mathrm{Ni} & 90 \\ \mathrm{Cr} & 195 \\ \mathrm{Ga} & 19 \\ \mathrm{Rb} & 11 \\ \mathrm{Sr} & 222 \\ \mathrm{Y} & 24 \\ \mathrm{Zr} & 120 \\ \mathrm{Nb} & 28 \\ \mathrm{Ba} & 167 \\ \mathrm{La} & 15 \\ \mathrm{Ce} & 36 \\ \mathrm{~Pb} & 5 \\ \mathrm{Th} & 6 \\ \mathrm{Zn} & 68\end{array}$

$\begin{array}{rr}86 & 107 \\ 195 & 201 \\ 19 & 18 \\ 4 & 5 \\ 239 & 217 \\ 23 & 22 \\ 122 & 113 \\ 28 & 28 \\ 127 & 106 \\ 15 & 15 \\ 33 & 30 \\ 4 & 5 \\ 3 & 1 \\ 72 & 70\end{array}$

$\begin{array}{rr}138 & 128 \\ 286 & 267 \\ 18 & 18 \\ 3 & \\ 285 & 3 \\ 21 & \\ 139 & 1 \\ 34 & \\ 175 & 2 \\ 19 & \\ 41 & \\ 3 & \\ 3 & \\ 71 & \end{array}$

$\begin{array}{rrr}128 & 130 & 14 \\ 267 & 314 & 27 \\ 18 & 18 & 1 \\ 4 & 5 & \\ 305 & 307 & 29 \\ 21 & 21 & 20 \\ 138 & 139 & 14 \\ 34 & 35 & 34 \\ 202 & 204 & 21 \\ 19 & 19 & 1 \\ 39 & 43 & 4 \\ 4 & 1 & \\ 5 & 1 & \\ 67 & 67 & 68\end{array}$

$\begin{array}{rr}142 & 141 \\ 272 & 258 \\ 18 & 18 \\ 4 & 5 \\ 295 & 300 \\ 20 & 21 \\ 141 & 142 \\ 34 & 35 \\ 216 & 191 \\ 18 & 19 \\ 42 & 44 \\ 4 & 5 \\ 4 & 2 \\ 68 & 68\end{array}$

$\begin{array}{rr}141 & 123 \\ 258 & 25 \\ 18 & 19 \\ 5 & \\ 300 & 298 \\ 21 & 21 \\ 142 & 142 \\ 35 & 36 \\ 191 & 18 \\ 19 & 20 \\ 44 & 4 \\ 5 & \\ 2 & \\ 68 & 67\end{array}$

$\begin{array}{rr}123 & 117 \\ 251 & 249 \\ 19 & 19 \\ 4 & 4 \\ 298 & 308 \\ 21 & 21 \\ 142 & 145 \\ 36 & 38 \\ 182 & 257 \\ 20 & 18 \\ 41 & 43 \\ 3 & 4 \\ 3 & 4 \\ 67 & 69\end{array}$

$\begin{array}{rr}117 & 115 \\ 249 & 252 \\ 19 & 18 \\ 4 & 12 \\ 308 & 309 \\ 21 & 21 \\ 145 & 137 \\ 38 & 35 \\ 257 & 221 \\ 18 & 18 \\ 43 & 37 \\ 4 & 4 \\ 4 & 3 \\ 69 & 64\end{array}$

$\begin{array}{rr}115 & 104 \\ 252 & 241 \\ 18 & 16 \\ 12 & 8 \\ 309 & 316 \\ 21 & 20 \\ 137 & 132 \\ 35 & 34 \\ 221 & 196 \\ 18 & 17 \\ 37 & 35 \\ 4 & 5 \\ 3 & 3 \\ 64 & 65\end{array}$

$\begin{array}{rrr}130 & 130 & 128 \\ 249 & 258 & 273 \\ 18 & 18 & 18 \\ 7 & 6 & 6 \\ 322 & 338 & 353 \\ 23 & 22 & 22 \\ 140 & 140 & 137 \\ 36 & 34 & 36 \\ 219 & 215 & 201 \\ 19 & 19 & 20 \\ 42 & 40 & 43 \\ 4 & 3 & 5 \\ 4 & 2 & 5 \\ 74 & 70 & 71\end{array}$

Selected element ratios

$\begin{array}{lcc}\mathrm{K} / \mathrm{Rb} & 483.0 & 809.3 \\ \mathrm{Rb} / \mathrm{Sr} & 0.050 & 0.017 \\ \mathrm{Ba} / \mathrm{Sr} & 0.75 & 0.53 \\ \mathrm{Zr} / \mathrm{Nb} & 4.3 & 4.4 \\ \mathrm{Zr} / \mathrm{ce} & 3.3 & 3.7 \\ \mathrm{Zr} / \mathrm{Y} & 5.0 & 5.3 \\ \mathrm{Ce} / \mathrm{Y}_{\mathrm{N}} & 3.67 & 3.51 \\ \mathrm{t} \mathrm{Fe} / \mathrm{Mg} & 1.5 & 1.6\end{array}$

$\begin{array}{cccc}730.5 & 1023.8 & 850.9 & 697.3 \\ 0.023 & 0.011 & 0.013 & 0.016 \\ 0.49 & 0.61 & 0.66 & 0.66 \\ 4.0 & 4.1 & 4.1 & 4.0 \\ 3.7 & 3.4 & 3.5 & 3.2 \\ 5.1 & 6.6 & 6.6 & 6.6 \\ 3.33 & 4.77 & 4.54 & 5.00 \\ 1.1 & 1.0 & 1.0 & 1.0\end{array}$

$\begin{array}{lll}892.4 & 763.7 & 8 \\ 0.014 & 0.017 & 0 . \\ 0.73 & 0.64 \\ 4.1 & 4.1 \\ 3.4 & 3.2 \\ 7.0 & 6.8 \\ 5.13 & 5.12 \\ 0.9 & 0.8\end{array}$

$\begin{array}{ll}809.3 & 850.9 \\ 0.013 & 0.013 \\ 0.61 & 0.83 \\ 3.9 & 3.8 \\ 3.5 & 3.4 \\ 6.8 & 6.9 \\ 4.77 & 5.00 \\ 1.0 & 1.0\end{array}$

$\begin{array}{ll}553.4 & 726 . \\ 0.039 & \\ 0.72 & \\ 3.9 & 0 . \\ 3.7 & 3 . \\ 6.5 & \\ 4.31 \\ 1.4\end{array}$

$\begin{array}{ll}726.3 & 735 . \\ 0.025 & \\ 0.62 & \\ 3.9 & 0 . \\ 3.8 & 3 . \\ 6.6 & 6 . \\ 4.28 \\ 1.4\end{array}$

$\begin{array}{ll}735.2 & 8 \\ 0.022 & \\ 0.68 & 0 . \\ 3.9 & \\ 3.3 & 4 . \\ 6.1 & \\ 4.46 & 6 . \\ 1.4 & 4 .\end{array}$

$\begin{array}{ll}816.3 & 747.1 \\ 0.018 & 0.017 \\ 0.64 & 0.57 \\ 4.1 & 3.8 \\ 3.5 & 3.2 \\ 6.4 & 6.2 \\ 4.44 & 4.78 \\ 1.4 & 1.6\end{array}$

$\begin{array}{lrr}\text { C.I.P.W. Norm } & & \\ \mathrm{Q} & 0.0 & 0.0 \\ \mathrm{Or} & 3.9 & 2.4 \\ \mathrm{Ab} & 24.1 & 25.0 \\ \mathrm{An} & 26.2 & 26.2 \\ \mathrm{Ne} & 0.0 & 0.7 \\ \mathrm{Di} & 25.3 & 30.2 \\ \mathrm{Hy} & 11.3 & 0.0 \\ \mathrm{Ol} & 4.3 & 10.5 \\ \mathrm{Mt} & 1.7 & 1.7 \\ \mathrm{Il} & 2.7 & 2.8 \\ \mathrm{Ap} & 0.4 & 0.4\end{array}$

$\begin{array}{rr}0.0 & 0.0 \\ 2.7 & 2.2 \\ 24.4 & 21.2 \\ 24.4 & 25.4 \\ 0.0 & 0.0 \\ 23.1 & 24.3 \\ 8.3 & 4.8 \\ 12.2 & 17.0 \\ 1.7 & 1.7 \\ 2.7 & 2.8 \\ 0.5 & 0.5\end{array}$

$\begin{array}{rr}0.0 & 0.0 \\ 2.5 & 2.5 \\ 24.1 & 22.4 \\ 25.2 & 25.3 \\ 0.0 & 0.9 \\ 24.5 & 26.1 \\ 1.1 & 0.0 \\ 17.7 & 17.7 \\ 1.7 & 1.6 \\ 2.7 & 2.8 \\ 0.6 & 0.6\end{array}$

$\begin{array}{rrr}0.0 & 0.0 & 0.0 \\ 2.6 & 2.8 & 2.4 \\ 16.0 & 22.3 & 23.0 \\ 26.1 & 24.3 & 24.3 \\ 2.7 & 0.0 & 0.5 \\ 27.6 & 24.1 & 27.9 \\ 0.0 & 0.3 & 0.0 \\ 20.0 & 21.4 & 16.8 \\ 1.6 & 1.5 & 1.6 \\ 2.7 & 2.6 & 2.8 \\ 0.5 & 0.6 & 0.6\end{array}$

$\begin{array}{rr}0.0 & 0.0 \\ 2.5 & 5.0 \\ 24.6 & 22.1 \\ 23.7 & 28.1 \\ 0.0 & 0.0 \\ 26.4 & 27.5 \\ 1.7 & 3.1 \\ 16.1 & 9.4 \\ 1.6 & 1.6 \\ 2.8 & 2.7 \\ 0.6 & 0.5\end{array}$

$\begin{array}{rrrr}0.0 & 0.0 & 0.0 & 0.0 \\ 4.4 & 3.8 & 3.7 & 3.4 \\ 11.1 & 20.7 & 20.8 & 20.7 \\ 27.2 & 24.2 & 27.6 & 26.7 \\ 5.0 & 4.3 & 1.6 & 3.5 \\ 41.9 & 31.1 & 30.4 & 29.8 \\ 0.0 & 0.0 & 0.0 & 0.0 \\ 5.6 & 10.6 & 10.7 & 10.5 \\ 1.5 & 1.6 & 1.6 & 1.7 \\ 2.6 & 2.9 & 2.8 & 2.9 \\ 0.5 & 0.6 & 0.7 & 0.8\end{array}$

Site 410 basalts. The difference in incompatible element contents between the most primitive and the most evolved Site 410 lavas would necessitate at least 50 per cent removal of crystals by fractional crystallization. Moreover, it is apparent from their normative compositions that considerable plagioclase would have to be removed. Removal of this plagioclase would strongly deplete the melt in $\mathrm{Sr}$, whereas by contrast $\mathrm{Sr}$ is appreciably higher in the more evolved basalts. The conclusion must be that plagioclase is not involved in the genesis of Site 410 basalts. Similar arguments can be made regarding removal of olivine or pyroxene, which would deplete the residual magma in $\mathrm{Ni}$ and $\mathrm{Cr}$ respectively: but this is not observed either. It would appear that Site 410 basalts, obviously consanguinous from their incompatible element relationships, must all be related by differing degrees of partial melting from a similar mantle source.

Cerium also exhibits a linear correlation with $\mathrm{Zr}$ (Figure 32 ), and the correlation appears to pass through or near zero. $\mathrm{Ce} / \mathrm{Zr}$ ratios and absolute $\mathrm{Ce}$ contents are higher than in the Reykjanes basalts. The relationship between $\mathrm{Y}$ and $\mathrm{Zr}$ (Figure 33) is very different from that in the Reykjanes basalts, however, since there is little or no increase in $\mathrm{Y}$ with increasing zirconium (or most of the other incompatible elements). The most probable explanation is that $Y$ is being retained in the source, but to a much greater extent than was observed for the Reykjanes basalts. This contrasting behavior of $\mathrm{Ce}$ and $\mathrm{Y}$ has a marked effect on $\mathrm{Ce} / \mathrm{Y}$ ratios (Figure 34) and it is clear that the more fractionated Site 410 lavas must have rather steep light-RE enriched rare earth patterns (although in reality the patterns are depleted in heavy RE).

Most consanguinous suites of ocean basalts show a convex curved relationship between $\mathrm{Y}$ and $\mathrm{Zr}$ (Figure 35), indicating that $\mathrm{Y}$ is more compatible than $\mathrm{Zr}$. Such was the case for Reykjanes basalts, for instance (Figure 27). However, the relationship is very variable. Where extensive crystal differentiation has taken place in high-level magma 


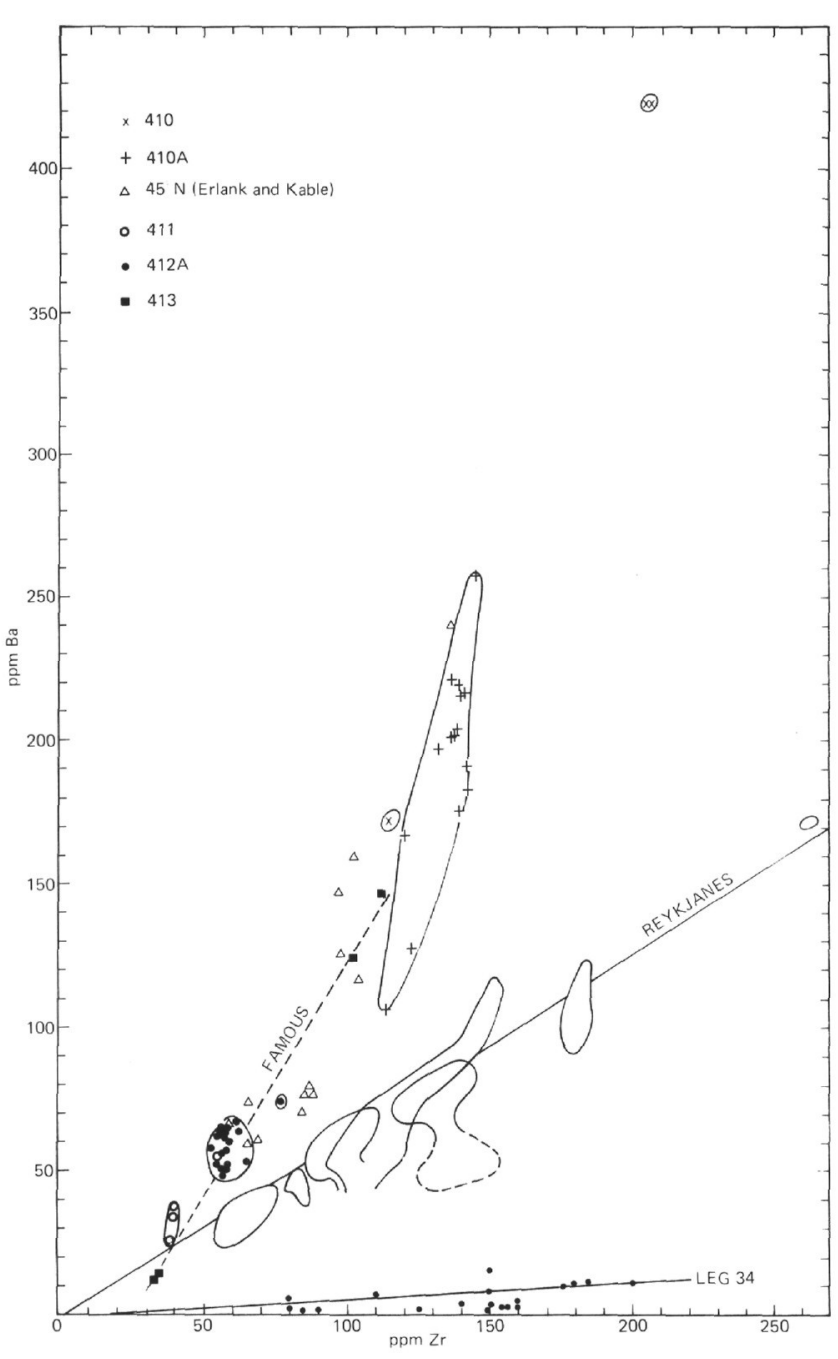

Figure 30. Ba versus $Z r$ for basalts from $45^{\circ} \mathrm{N}$ and $\mathrm{FA}$ MOUS sites. Data points for the median valley at $45^{\circ} \mathrm{N}$ from Erlank and Kable (1976) and for Nazca Plate basalts (Leg 34) from Thompson et al. (1976). Fields for Reykjanes basalts shown for comparison.

chambers, as at Deception volcano (Tarney et al., 1977), Y behaves in a less compatible fashion with regard to the separating phases (olivine, plagioclase, clinopyroxene), and the curvature is slight. Where partial melting is the controlling process, as in Scotia Sea basalts (Tarney et al., 1977; Saunders, Tarney, Weavèr, and Barker, in press), there is greater curvature, but the bulk distribution coefficient for $\mathrm{Y}$ in such cases still appears to be less than one. In Site 410 basalts, however, the bulk distribution coefficient for Y must be close to unity. This may imply either that an additional mineral, such as garnet or hornblende, is present among the refractory mantle phases, or that partition coefficients for $\mathrm{Y}$ in clinopyroxene are pressure-sensitive and increase with pressure. It is interesting to note that $\mathrm{Ti}$ behaves in a fashion identical to $\mathrm{Y}$ in Site 410 basalts (Figure 36), and that $\mathrm{Ti} / \mathrm{Y}$ ratios for all Site 410 basalts are confined within the range for all Leg 49 basalts (Figure 37 ). This strongly implies that the phase

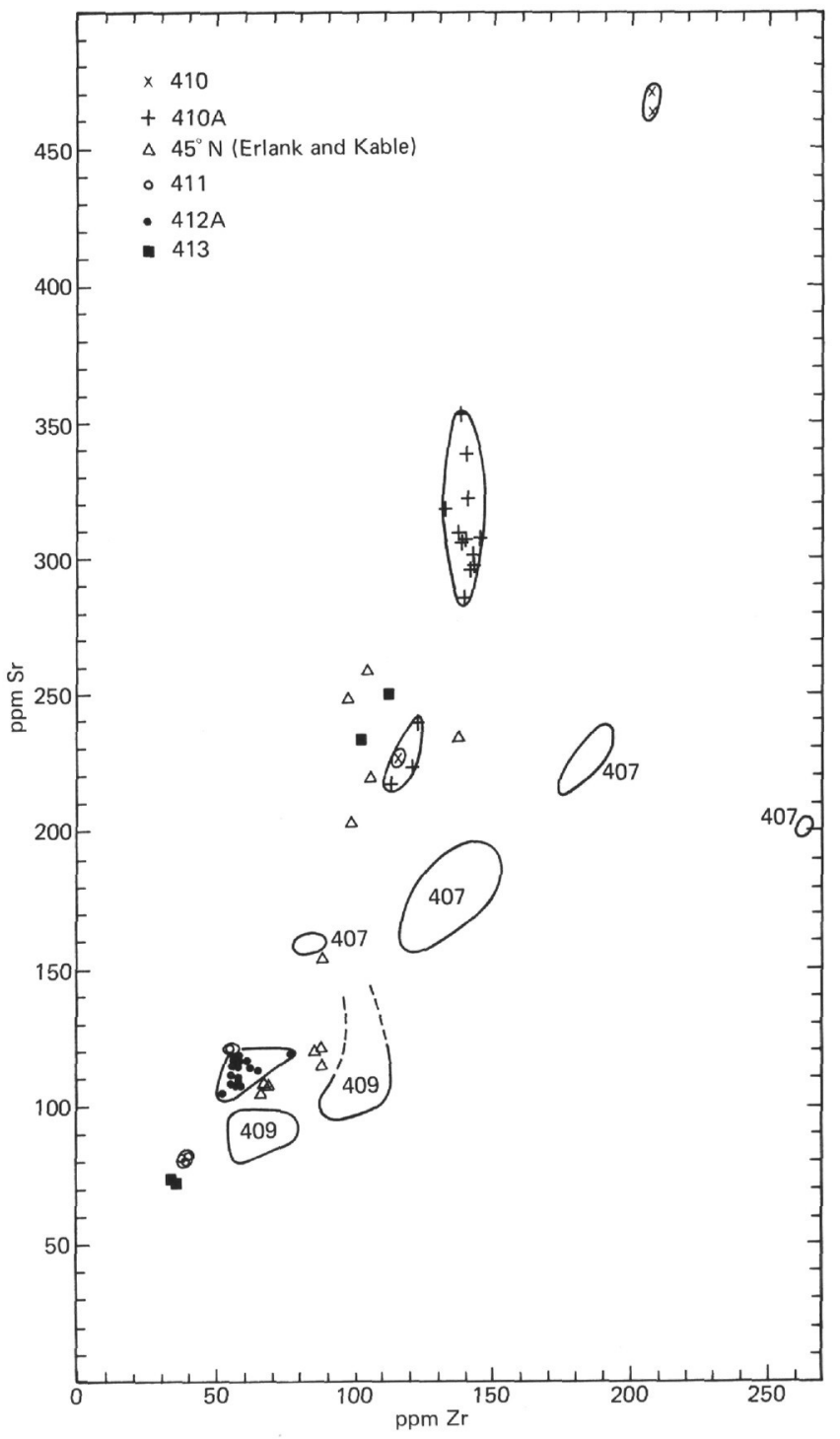

Figure 31. Sr versus $\mathrm{Zr}$ for basalts from $45^{\circ} \mathrm{N}$ and $\mathrm{FA}$ MOUS sites. Data points for the median valley at $45^{\circ} \mathrm{N}$ from Erlank and Kable (1976). Fields for Reykjanes basalts shown for comparison.

which is retaining $\mathrm{Y}$ is retaining $\mathrm{Ti}$ in the same proportion as in other basalt suites, but retaining both to a greater degree. It is unlikely that refractory garnet would retain $\mathrm{Ti}$ in the same proportion as $\mathrm{Y}$, since partition coefficients for $\mathrm{Y}$ in garnet are very high. Likewise, it is unlikely that a refractory Ti-rich phase would retain $\mathrm{Y}$ in the same proportion. Hornblendes may be Ti-rich and have higher partition coefficients for $\mathrm{Y}$ than clinopyroxene (cf. Arth and Barker, 1977). Although hornblende may exist as a stable mantle phase, however (Basu and Murthy, 1977), it is doubtful that it could survive a partial melting episode (Lambert and Wyllie, 1968). Note that $\mathrm{P}_{2} \mathrm{O}_{5} / \mathrm{Zr}$ ratios in Site 410 basalts are similar to those in other Leg 49 basalts (Figure 23); however, the most fractionated Site 410 lavas have a distinctly lower $\mathrm{P}_{2} \mathrm{O}_{5} / \mathrm{Zr}$ ratio, suggesting that phosphorus may be behaving more compatibly, but not to the same extent as $\mathrm{Y}$ and Ti. 


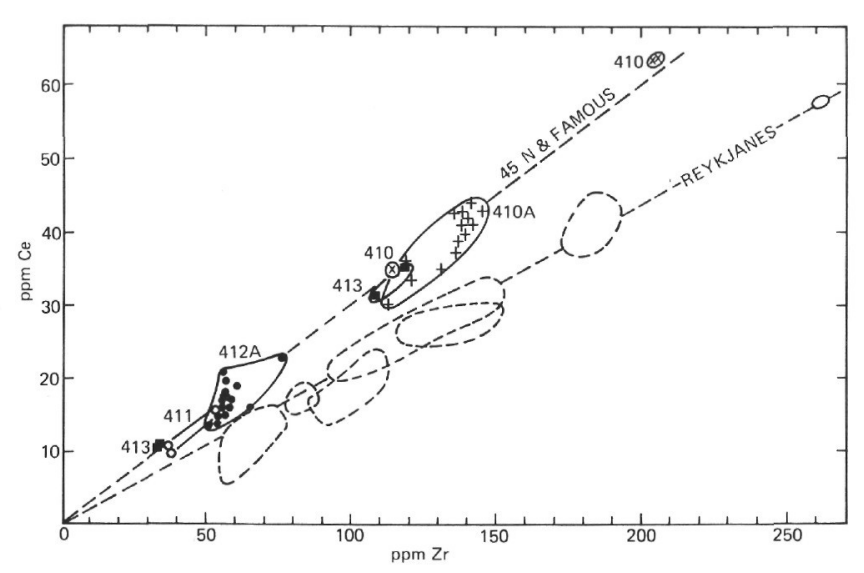

Figure 32. Ce versus $\mathrm{Zr}$ for basalts from $45^{\circ} \mathrm{N}$ and $\mathrm{FA}$ MOUS sites. Fields for Reykjanes basalts shown for comparison.

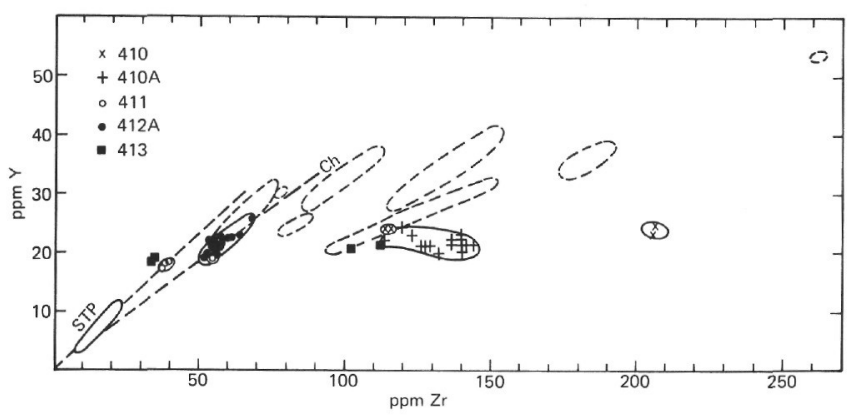

Figure 33. $Y$ versus $Z r$ for basalts from $45^{\circ} \mathrm{N}$ and $F A M O U S$ sites. Fields for Reykjanes basalts shown for comparison.

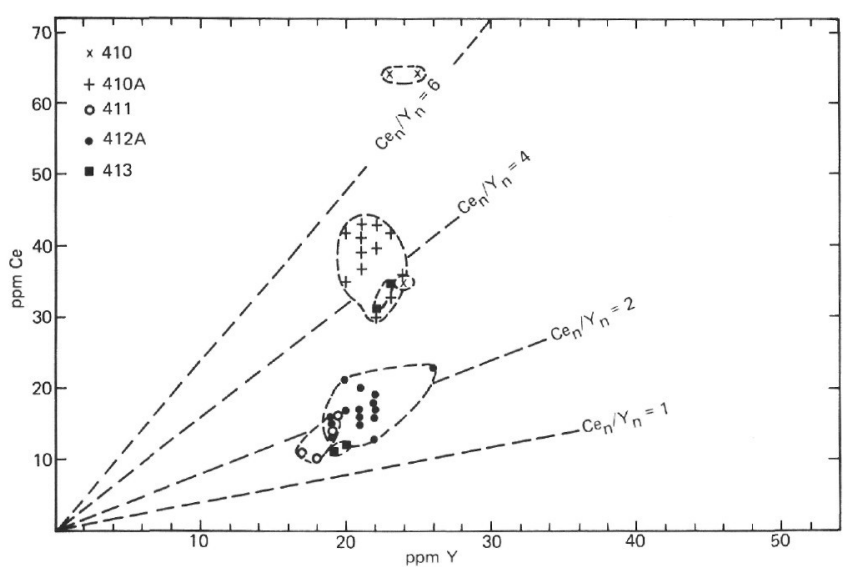

Figure 34. Ce versus $Y$ for basalts from $45^{\circ} \mathrm{N}$ and $F A M O U S$ sites. Lines indicate chondrite-normalized $\mathrm{Ce} / \mathrm{Y}$ ratio values.

In summary, Site 410 basalts are geochemically distinct from Reykjanes basalts, not only with respect to element ratios and their more transitional alkalic compositions, but also with regard to their petrogenesis. Elements such as $\mathrm{Ba}$, $\mathrm{Sr}, \mathrm{Nb}$ (? $\mathrm{K}$ and $\mathrm{Rb}$ ) appear to behave in a more

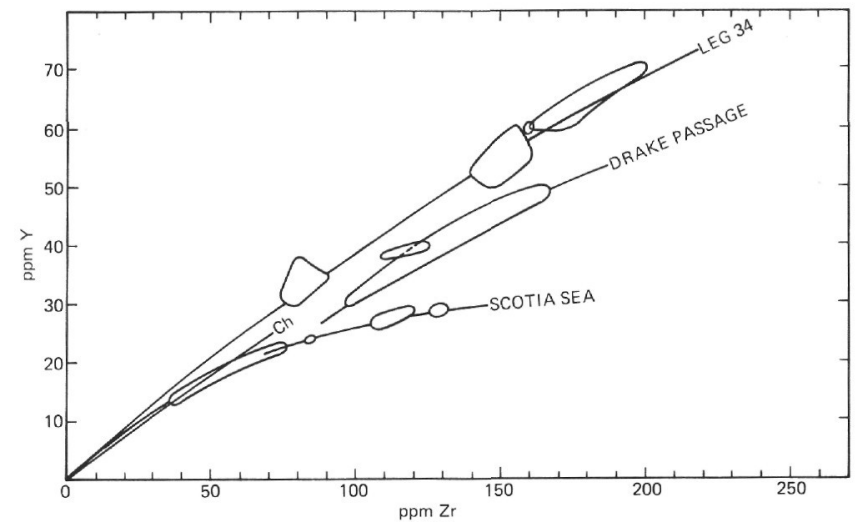

Figure 35. $Y$ versus $Z r$ relationships in basalts from the Nazca Plate, Leg 34 (Rhodes et al., 1976; Thompson et al., 1976), Drake Passage Spreading Center, Scotia Sea (Saunders, Tarney, Weaver, and Barker, in press), and the South Sandwich Spreading Center, Scotia Sea (Tarney et al., 1977). $\mathrm{CH}$ is $\mathrm{Zr} / \mathrm{Y}$ ratio for chondrites.

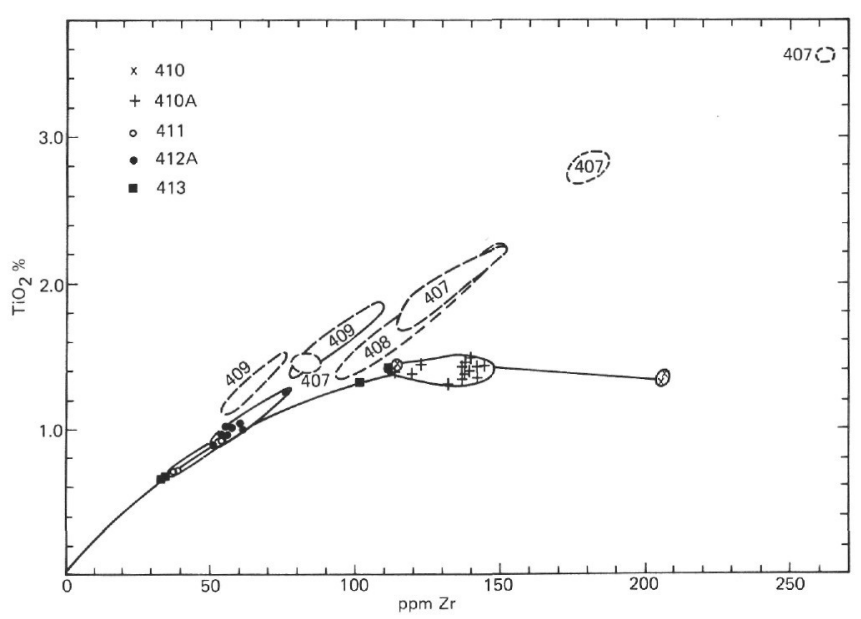

Figure 36. $\mathrm{TiO}_{2}$ versus $\mathrm{Zr}$ for basalts from $45^{\circ} \mathrm{N}$ and $\mathrm{FA}$ MOUS sites. Dashed fields-Reykjanes basalts.

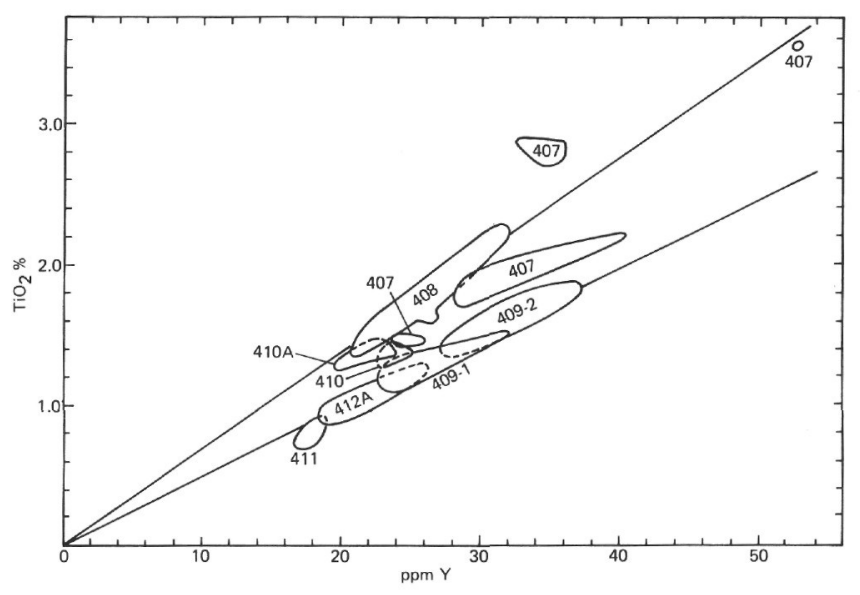

Figure 37. $\mathrm{TiO}_{2}$ versus $Y$ for Leg 49 basalts. Over 90 per cent of the data points fall between the two lines. 
incompatible fashion than $\mathrm{Zr}$, while $\mathrm{Ti}$ and $\mathrm{Y}$ (and ? P) are distinctly more compatible. By contrast, there is a much greater degree of coherence between these elements in the Reykjanes basalts. Additional mineral phases and/or greater depths of partial melting would seem to be required. There is also the possibility of vertical heterogeneity in the mantle source. The notably higher $\mathrm{K}, \mathrm{Rb}$, and $\mathrm{Ba}$ contents at Site 410 could indicate the presence of phlogopite as a primary mantle phase, but if so, phlogopite cannot be a stable refractory phase, because the dominant constituents of phlogopite $(\mathrm{K}, \mathrm{Rb}, \mathrm{Ba})$ appear to have been released into the partial melt before the other normally incompatible elements. Further detailed studies on $45^{\circ} \mathrm{N}$ basalts are clearly needed to solve some of these problems.

Basalts dredged on the Discovery and Hudson cruises near the median valley at $45^{\circ} \mathrm{N}$ are in their geochemistry remarkably similar to those at Site 410 (Muir and Tilley, 1964; Aumento, 1968; Erlank and Kable, 1976). Not only are tholeiitic, transitional, and alkali basalts represented, but they exhibit similar trace-element abundances and trace-element ratios (Figures 30, 24, and 31). It would appear in fact that $45^{\circ} \mathrm{N}$ basalts can be treated as a coherent geochemical group, irrespective of age. For instance, it is apparent from the data of Muir and Tilley (1964), Aumento (1968), and Erlank and Kable (1976) that both Ti and Y are being retained in the source just as they are at Site 410 . Moreover, elements such as $\mathrm{K}, \mathrm{Rb}, \mathrm{Ba}$, and $\mathrm{Sr}$ are behaving more incompatibly than $\mathrm{Zr}$. Samples from the median valley are enriched in light REE (Frey et al., 1968), have ${ }^{87} \mathrm{Sr} /{ }^{86} \mathrm{Sr}$ ratios as high as 0.7033 (Hart, 1971b; Erlank and Kable, 1976), and are enriched in Cs (Hart, 1971a) and U (Aumento, 1971; Aumento and Hyndman, 1971). Erlank and Kabel (1976) considered the differences between $45^{\circ} \mathrm{N}$ basalts and MORB to reflect geochemical differences in the mantle source regions. Site 410 data confirm and amplify this suggestion and confirm the findings from the Reykjanes transect that such differences persist for many millions of years and that the volume of mantle involved must therefore be very large.

\section{FAMOUS AREA SITES}

Basalts were recovered from three sites $(411,412$, and 413 ) in the FAMOUS area at $36^{\circ} \mathrm{N}$, thus allowing comparisons to be made with the comprehensive body of data produced as a result of drilling on Leg 37 , and also the extensive dredged material.

Site 411 , at $36^{\circ} 45.97^{\prime} \mathrm{N}, 33^{\circ} 23.30^{\prime} \mathrm{W}$, is the youngest site drilled by DSDP ( 1 million years), and is in 1935 meters of water. Drilling difficulties forced abandonment of the hole after only 45 meters of basalt had been penetrated, and only 4 meters of basalt were recovered. Aphyric and olivine and plagioclase-phyric basalts, some with up to 20 per cent feldspar phenocrysts, make up most of the core, but there is considerable lithologic variation in the samples recovered. Chemically there are two units at Site 411; the lower one (Cores 4 and 5) is more evolved than the upper one (Cores 1 to 3 ).

Site 412 , at $36^{\circ} 33.74^{\prime} \mathrm{N}, 33^{\circ} 09.96^{\prime} \mathrm{W}$, is one mile south of the north wall of fracture zone $B$, and was drilled into crust only 1.6 m.y. old. After failure of the experimental bit in Hole 412, a second hole (412A) penetrated 123 meters of basement beneath 165 meters of sediment. The top five cores (Cores 1 through 5) are largely fine to coarse-grained olivine-plagioclase phyric ( 5 to $20 \%$ ) basalt with occasional clinopyroxene phenocrysts, although some sparsely phyric basalts also occur. The lower cores (Cores 6 through 14) are aphyric to sparsely phyric basalts. Chemically, however, there are no sharp breaks to separate these upper and lower units, although there is a moderate amount of compositional variation at Site 412 .

Site 413 , at $36^{\circ} 32.6^{\prime} \mathrm{N}, 33^{\circ} 10.5^{\prime} \mathrm{W}$, was drilled only 1.3 miles south of Site 412 , but on the south side of the fracture zone valley, and into crust about $3.5 \mathrm{~m}$.y. old. The site was chosen particularly to test the geochemical comparability of these two sites, so close, yet with a 2-m.y. age difference. A total of 39 meters of basalt was penetrated. This proved to be even-textured aphyric basalt with rare microphenocrysts of plagioclase and/or olivine.

All the FAMOUS site basalts are relatively fresh, and as a result there is a rather close clustering of points for most major and trace elements in almost all the inter-element plots. Basalts from the upper unit at Site 411 are olivine-hypersthene-normative tholeiitic basalts (Figure 29) with over 15 per cent normative olivine. They have the lowest levels of incompatible elements of any of the basalts recovered on Leg 49, and have the highest contents of $\mathrm{Cr}$ and Ni (Table 7). Similar basalts with high $\mathrm{Cr}$ and Ni were recovered from the FAMOUS area on Leg 37. These features suggest they were generated by high degrees of mantle melting. The lower unit at Site 411 is compositionally very different, but clearly consanguinous. The single sample provided from this unit has a trace of normative quartz, and plots close to the Di-Hy join on the Ol-Di-Hy diagram (Figure 29). This sample has only about a quarter of the amount of $\mathrm{Cr}$ and $\mathrm{Ni}$ seen in the upper unit, and a much higher Fe/ $\mathrm{Mg}$ ratio (Table 7). Correspondingly, the levels of all incompatible elements are higher. The increase in the incompatible element levels would demand about 30 to 40 per cent removal of crystals if the two units were to be related by crystal fractionation in a sub-axis magma chamber. The marked reduction in $\mathrm{Ni}$ and $\mathrm{Cr}$ could be accomplished by extensive separation of olivine and Cr-spinel. This would at the same time account for the observed increase in silica and the trend toward quartz-normative compositions in the lower unit. However, in spite of the fact that Site 411 basalts are strongly plagioclase-phyric, little plagioclase must have been removed in relating the two units, because $\mathrm{Sr}$ is 50 per cent higher in the more fractionated lower unit. Some doubt is cast on fractional crystallization as a mechanism relating these two units, however, since $\mathrm{TiO}_{2}$ shows only a slight increase and $\mathrm{Y}$ virtually no increase in the lower unit; yet neither Ti nor $\mathrm{Y}$ would be removed from the melt by separation of olivine or $\mathrm{Cr}$-spinel. The opposite effect is seen with $\mathrm{K}_{2} \mathrm{O}, \mathrm{Rb}$, and to a smaller extent $\mathrm{Ba}$, all of which show a considerably greater enrichment than would be predicted by a fractional crystallization model. Curiously, these paired, but opposite effects with regard to Ti-Y and to $\mathrm{K}-\mathrm{Rb}-\mathrm{Ba}$ are similar to those found at Site 410 . This would imply that the two units at Site 411 might be related by a 
TABLE 7

Analyses of Basalts From Hole 411, Leg 49

\begin{tabular}{lcccc}
\hline Core-Section & $1-1$ & $2-2$ & $3-1$ & $4-1$ \\
Interval $(\mathrm{cm})$ & $28-82$ & $2-13$ & $94-100$ & $60-70$ \\
\multicolumn{1}{c}{ Piece } & $8 \mathrm{~B}$ & 1 & 13 & 8 \\
\hline $\mathrm{SiO}_{2}$ & 47.67 & 47.51 & 48.12 & 50.12 \\
$\mathrm{TiO}_{2}$ & 0.72 & 0.72 & 0.73 & 0.93 \\
$\mathrm{Al}_{2} \mathrm{O}_{3}$ & 15.3 & 15.0 & 15.2 & 16.9 \\
$\mathrm{Fe}_{2} \mathrm{O}_{3}$ & 10.21 & 10.30 & 9.99 & 8.77 \\
$\mathrm{MnO}$ & 0.17 & 0.17 & 0.16 & 0.15 \\
$\mathrm{MgO}$ & 11.21 & 11.88 & 11.08 & 6.21 \\
$\mathrm{CaO}$ & 12.10 & 12.00 & 12.29 & 12.77 \\
$\mathrm{Na} 2 \mathrm{O}$ & 1.78 & 1.75 & 1.80 & 2.26 \\
$\mathrm{~K}_{2} \mathrm{O}$ & 0.04 & 0.03 & 0.06 & 0.16 \\
$\mathrm{P}_{2} \mathrm{O}$ & 0.050 & 0.048 & 0.048 & 0.088 \\
Total & 99.2 & 99.4 & 99.5 & 98.3
\end{tabular}

Trace elements in ppm

$\mathrm{Ni} \quad 227$

$\mathrm{Cr} \quad 532$

$\mathrm{Ga} \quad 14$

$\mathrm{Rb}$

$\mathrm{Sr}$

$\mathrm{Y}$

$\mathrm{Zr}$

$\mathrm{Nb}$

$\mathrm{Ba}$

$\mathrm{La}$

$\mathrm{Ce}$

$\mathrm{Pb}$

Th

$\mathrm{Zn}$

243
565
14
1
82
17
38
8
25
4
11
3
-1
58

$\begin{array}{rr}225 & 55 \\ 558 & 162 \\ 15 & 17 \\ 1 & 3 \\ 82 & 121 \\ 18 & 19 \\ 39 & 55 \\ 9 & 11 \\ 34 & 55 \\ 2 & 5 \\ 10 & 16 \\ 4 & 2 \\ 1 & 2 \\ 55 & 63\end{array}$

Selected element ratios

\begin{tabular}{lcccc}
$\mathrm{K} / \mathrm{Rb}$ & 332.0 & 249.0 & 498.1 & 442.7 \\
$\mathrm{Rb} / \mathrm{Sr}$ & 0.013 & 0.012 & 0.012 & 0.025 \\
$\mathrm{Ba} / \mathrm{Sr}$ & 0.46 & 0.30 & 0.41 & 0.45 \\
$\mathrm{Zr} / \mathrm{Nb}$ & 4.9 & 4.7 & 4.3 & 5.0 \\
$\mathrm{Zr} / \mathrm{Ce}$ & 3.9 & 3.5 & 3.9 & 3.4 \\
$\mathrm{Zr} / \mathrm{Y}$ & 2.2 & 2.2 & 2.2 & 2.9 \\
$\mathrm{Ce} / \mathrm{YN}$ & 1.36 & 1.58 & 1.36 & 2.07 \\
$\mathrm{tFe} / \mathrm{Mg}$ & 1.1 & 1.0 & 1.0 & 1.6 \\
& & & & \\
$\mathrm{C.I.P.W.} \mathrm{Norm}$ & & & & \\
$\mathrm{Q}$ & 0.0 & 0.0 & 0.0 & 1.1 \\
$\mathrm{Or}$ & 0.2 & 0.2 & 0.4 & 1.0 \\
$\mathrm{Ab}$ & 15.3 & 15.0 & 15.4 & 19.6 \\
$\mathrm{An}$ & 34.2 & 33.4 & 33.7 & 36.3 \\
$\mathrm{Ne}$ & 0.0 & 0.0 & 0.0 & 0.0 \\
$\mathrm{Di}$ & 21.4 & 21.5 & 22.4 & 22.9 \\
$\mathrm{Hy}$ & 10.6 & 9.7 & 11.2 & 15.5 \\
$\mathrm{Al}$ & 14.8 & 16.7 & 13.5 & 0.0 \\
$\mathrm{Mt}$ & 1.8 & 1.8 & 1.8 & 1.6 \\
$\mathrm{Il}$ & 1.4 & 1.4 & 1.4 & 1.8 \\
$\mathrm{Ap}$ & 0.1 & 0.1 & 0.1 & 0.2 \\
\hline
\end{tabular}

partial melting process rather than by fractional crystallization, as has been suggested for other FAMOUS basalts (Langmuir et al., 1977).

Basalts from Site 412 (Table 8) are compositionally very similar to those of the lower unit at Site 411. Normatively they plot near the Di-Hy join on the Ol-Di-Hy diagram (Figure 29), and a proportion have minor amounts of normative quartz. Incompatible element abundances are also very similar, including values for $\mathrm{K}_{2} \mathrm{O}$ and $\mathrm{Rb}$ (which might be expected to show the greatest differences, since they are so susceptible to alteration processes). As a result, the basalt from the lower unit, Site 411, plots within or adjacent to the field for Hole $412 \mathrm{~A}$ basalts on most of the inter-element plots. Even the $\mathrm{CeN}_{\mathrm{N}} / \mathrm{Y}_{\mathrm{N}}$ ratios are similar (Figure 34), and clearly different from that of the upper unit at Site 411 (thus confirming the arguments above that the two units at Site 411 are probably related by partial melting processes rather than by fractional crystallization). Considering the age difference between Sites 411 and 412, the compositional similarity is quite striking — but merely confirms the findings, at $45^{\circ} \mathrm{N}$ and Reykjanes, that basalts of similar composition are erupted at the same ridge segment over long periods of time.

There is some variability in the basalts at Site 412 , but there are no consistent downhole trends. One sample from Core 4 has higher incompatible-element abundances, and is clearly more evolved. However, all such variations within Hole $412 \mathrm{~A}$ basalts display a reasonable degree of covariance between $\mathrm{Zr}$ and other incompatible elements, including $\mathrm{Y}$ and $\mathrm{TiO}_{2}$, so that it is likely that the compositional variation could be accomplished by fractional crystallization. $\mathrm{Ni}$ and especially $\mathrm{Cr}$ show a wide range of values, which broadly correlate with $\mathrm{Fe} / \mathrm{Mg}$ ratio, and could be accounted for by separation of olivine and $\mathrm{Cr}$-spinel.

Basalts from Site 413 group into two very distinct geochemical units (Table 9). This chemical difference is rather surprising, in view of the limited penetration at Site 413 and the petrographic similarities between the two units. Basalts from both the upper unit (Cores 1 and 2) and the lower unit (Cores 4 and 5) have high $\mathrm{Mg} / \mathrm{Fe}$ ratios and high $\mathrm{Cr}$ and $\mathrm{Ni}$ contents, and must represent primitive mantlements with little pre-eruptive fractional crystallization. Compositionally, all plot near the Di-Ol join on the normative Di-Ol-Hy diagram (Figure 29). The lower unit is more aluminous, and has more calcic-normative plagioclase.

Incompatible trace element levels are very much higher in the upper unit, however. $\mathrm{Ba}$ is higher by a factor of ten; $\mathrm{K} 2 \mathrm{O}, \mathrm{Rb}$, and $\mathrm{Nb}$ by a factor of five; $\mathrm{P}_{2} \mathrm{O}_{5}, \mathrm{Zr}, \mathrm{Sr}, \mathrm{Ce}$, and La by a factor of three to four, Ti by a factor of two; whereas $\mathrm{Na}_{2} \mathrm{O}, \mathrm{Y}, \mathrm{Zn}$, and $\mathrm{Pb}$ are little different in the two units. With these major differences in trace element levels but with negligible difference in $\mathrm{Fe} / \mathrm{Mg}$ ratio, it is inconceivable that these two units could be related by fractional crystallization. They must therefore represent individual batch melts, but whether from a chemically homogeneous or from two chemically distinct mantle sources remains to be determined. The latter remains a distinct possibility, considering that Hole 413 is close to a fracture zone. It is notable that ratios such as $\mathrm{Zr} / \mathrm{Nb}$ and $\mathrm{Zr} / \mathrm{Ba}$ are very different in the two units, whereas in the Reykjanes basalts these ratios are invariant, although the Reykjanes basalts encompass a fairly wide range of partial melting. $\mathrm{Ce} / \mathrm{Y}$ and $\mathrm{Zr} / \mathrm{Y}$ ratios are also different in the two Site 413 units (Figure 34), though $\mathrm{Zr} / \mathrm{Ce}$ and $\mathrm{Zr} / \mathrm{La}$ ratios are similar and equivalent to the ratios in other FAMOUS basalts (Figure 32). (Too much reliance must not be placed on the quoted Ce values for the lower unit at Site 413, owing to spectral interference from chromium.) 
TABLE 8

Analyses of Basalts From Hole 412A, Leg 49

\begin{tabular}{|c|c|c|c|c|c|c|c|c|c|c|c|}
\hline $\begin{array}{c}\text { Core-Section } \\
\text { Interval }(\mathrm{cm}) \\
\text { Piece }\end{array}$ & $\begin{array}{c}1-1 \\
28-37 \\
3\end{array}$ & $\begin{array}{c}2-2 \\
35-30 \\
3\end{array}$ & $\begin{array}{c}3-1 \\
70-80 \\
9\end{array}$ & $\begin{array}{c}3-2 \\
60-62 \\
7\end{array}$ & $\begin{array}{c}3-2 \\
70-80 \\
4 \mathrm{~B}\end{array}$ & $\begin{array}{c}4-1 \\
20-25 \\
3\end{array}$ & $\begin{array}{c}5-1 \\
50-54 \\
5\end{array}$ & $\begin{array}{c}6-1 \\
70-73 \\
6\end{array}$ & $\begin{array}{c}7-1 \\
2-5 \\
2\end{array}$ & $\begin{array}{c}7-1 \\
110-115 \\
-\end{array}$ & $\begin{array}{c}8-1 \\
130-133 \\
17\end{array}$ \\
\hline $\mathrm{SiO}_{2}$ & 49.82 & 50.21 & 49.76 & 50.51 & 49.84 & 50.43 & 50.36 & 50.46 & 49.81 & 50.83 & 50.42 \\
\hline $\mathrm{TiO}_{2}$ & 11.02 & 0.96 & 0.94 & 0.97 & 0.90 & 1.27 & 1.04 & 1.00 & 1.01 & 1.02 & 0.99 \\
\hline $\mathrm{Al}_{2} \mathrm{O}_{3}$ & 15.0 & 15.4 & 15.6 & 14.7 & 14.7 & 14.6 & 14.5 & 14.8 & 14.9 & 15.3 & 15.0 \\
\hline $\mathrm{Fe}_{2} \mathrm{O}_{3}$ & 10.29 & 9.50 & 9.09 & 10.00 & 9.79 & 10.97 & 10.65 & 10.36 & 10.29 & 10.13 & 10.11 \\
\hline $\mathrm{MnO}$ & 0.16 & 0.15 & 0.14 & 0.16 & 0.15 & 0.16 & 0.17 & 0.16 & 0.17 & 0.17 & 0.17 \\
\hline $\mathrm{MgO}$ & 8.07 & 9.03 & 7.92 & 8.95 & 10.43 & 8.21 & 8.78 & 8.41 & 7.36 & 6.67 & 8.22 \\
\hline $\mathrm{CaO}$ & 11.84 & 12.19 & 12.11 & 11.79 & 12.07 & 11.32 & 11.70 & 12.00 & 12.03 & 12.46 & 11.99 \\
\hline $\mathrm{Na}_{2} \mathrm{O}$ & 2.02 & 2.03 & 2.12 & 2.12 & 1.92 & 2.31 & 2.09 & 2.02 & 2.08 & 2.22 & 1.96 \\
\hline $\mathrm{K}_{2} \mathrm{O}$ & 0.18 & 0.15 & 0.15 & 0.16 & 0.14 & 0.16 & 0.13 & 0.11 & 0.18 & 0.21 & 0.22 \\
\hline $\mathrm{P}_{2} \mathrm{O}_{5}$ & 0.105 & 0.107 & 0.123 & 0.120 & 0.106 & 0.148 & 0.116 & 0.103 & 0.100 & 0.099 & 0.104 \\
\hline Total & 98.5 & 99.7 & 98.0 & 99.5 & 100.0 & 99.5 & 99.5 & 99.4 & 98.0 & 99.1 & 99.2 \\
\hline
\end{tabular}

\section{Trace elements in ppm}

\begin{tabular}{|c|c|c|c|c|c|c|c|c|c|c|c|}
\hline $\mathrm{Ni}$ & 60 & 98 & 97 & 65 & 161 & 68 & 58 & 59 & 62 & 50 & 62 \\
\hline $\mathrm{Cr}$ & 91 & 333 & 265 & 103 & 464 & 144 & 90 & 99 & 95 & 89 & 103 \\
\hline $\mathrm{Ga}$ & 16 & 15 & 15 & 14 & 16 & 17 & 15 & 17 & 17 & 17 & 15 \\
\hline $\mathrm{Rb}$ & 2 & 4 & 4 & 4 & 3 & 2 & 2 & 2 & 3 & 4 & 4 \\
\hline $\mathrm{Sr}$ & 109 & 111 & 114 & 114 & 104 & 119 & 116 & 115 & 118 & 120 & 118 \\
\hline $\mathrm{Y}$ & 22 & 19 & 19 & 20 & 19 & 26 & 22 & 19 & 20 & 21 & 21 \\
\hline $\mathrm{Zr}$ & 58 & 55 & 56 & 57 & 52 & 77 & 61 & 57 & 56 & 57 & 58 \\
\hline $\mathrm{Nb}$ & 13 & 12 & 12 & 12 & 12 & 15 & 12 & 13 & 12 & 13 & 12 \\
\hline $\mathrm{Ba}$ & 57 & 62 & 64 & 63 & 58 & 74 & 67 & 61 & 51 & 56 & 60 \\
\hline La & 6 & 7 & 7 & 7 & 5 & 7 & 7 & 6 & 6 & 5 & 6 \\
\hline $\mathrm{Ce}$ & 17 & 14 & 16 & 17 & 13 & 23 & 19 & 14 & 21 & 17 & 20 \\
\hline $\mathrm{Pb}$ & 2 & 3 & 2 & 3 & 3 & 3 & 3 & 2 & 22 & 3 & 5 \\
\hline Th & $<1$ & 1 & $<1$ & 1 & $<1$ & 2 & 3 & $<1$ & $<1$ & $<1$ & $<1$ \\
\hline $\mathrm{Zn}$ & 70 & 68 & 67 & 67 & 70 & 76 & 65 & 69 & 74 & 71 & 68 \\
\hline
\end{tabular}

Selected element ratios

\begin{tabular}{|c|c|c|c|c|c|c|c|c|c|c|c|}
\hline $\mathrm{K} / \mathrm{Rb}$ & 747.1 & 311.3 & 311.3 & 332.0 & 387.4 & 664.1 & 539.6 & 456.6 & 498.1 & 435.8 & 456.6 \\
\hline $\mathrm{Rb} / \mathrm{Sr}$ & 0.018 & 0.036 & 0.035 & 0.035 & 0.029 & 0.017 & 0.017 & 0.017 & 0.025 & 0.033 & 0.034 \\
\hline $\mathrm{Ba} / \mathrm{Sr}$ & 0.57 & 0.56 & 0.56 & 0.55 & 0.56 & 0.62 & 0.58 & 0.53 & 0.43 & 0.47 & 0.51 \\
\hline $\mathrm{Zr} / \mathrm{Nb}$ & 4.5 & 4.6 & 4.7 & 4.7 & 4.3 & 5.1 & 5.1 & 4.4 & 4.7 & 4.4 & 4.8 \\
\hline $\mathrm{Zr} / \mathrm{Ce}$ & 3.4 & 3.9 & 3.5 & 3.4 & 4.0 & 3.4 & 3.2 & 4.1 & 2.7 & 3.4 & 2.9 \\
\hline $\mathrm{Zr} / \mathrm{Y}$ & 2.6 & 2.9 & 3.0 & 2.9 & 2.7 & 3.0 & 2.8 & 3.0 & 2.8 & 2.7 & 2.8 \\
\hline $\mathrm{Ce}_{\mathrm{N}} / \mathrm{Y}_{\mathrm{N}}$ & 1.89 & 1.80 & 2.06 & 2.08 & 1.67 & 2.16 & 2.11 & 1.80 & 2.57 & 1.98 & 2.33 \\
\hline $\mathrm{tFe} / \mathrm{Mg}$ & 1.5 & 1.2 & 1.3 & 1.3 & 1.1 & 1.5 & 1.4 & 1.4 & 1.6 & 1.8 & 1.4 \\
\hline \multicolumn{12}{|c|}{ C.I.P.W. Norm } \\
\hline Q & 0.3 & 0.0 & 0.2 & 0.0 & 0.0 & 0.1 & 0.0 & 0.6 & 0.9 & 1.6 & 0.8 \\
\hline Or & 1.1 & 0.9 & 0.9 & 1.0 & 0.8 & 1.0 & 0.8 & 0.7 & 1.1 & 1.3 & 1.3 \\
\hline $\mathrm{Ab}$ & 17.5 & 17.4 & 18.4 & 18.2 & 16.4 & 19.8 & 17.9 & 17.3 & 18.1 & 19.1 & 16.9 \\
\hline An & 32.1 & 32.8 & 33.6 & 30.5 & 31.2 & 29.3 & 30.2 & 31.4 & 31.8 & 31.7 & 32.0 \\
\hline $\mathrm{Ne}$ & 0.0 & 0.0 & 0.0 & 0.0 & 0.0 & 0.0 & 0.0 & 0.0 & 0.0 & 0.0 & 0.0 \\
\hline Di & 22.3 & 22.4 & 22.3 & 22.8 & 23.0 & 21.8 & 22.7 & 23.1 & 23.7 & 25.1 & 22.6 \\
\hline Hy & 22.6 & 20.6 & 20.8 & 22.8 & 18.6 & 23.3 & 23.9 & 22.9 & 20.2 & 17.2 & 22.4 \\
\hline $\mathrm{Al}$ & 0.0 & 2.1 & 0.0 & 0.8 & 6.2 & 0.0 & 0.3 & 0.0 & 0.0 & 0.0 & 0.0 \\
\hline Mt & 1.8 & 1.7 & 1.6 & 1.8 & 1.7 & 1.9 & 1.9 & 1.8 & 1.8 & 1.8 & 1.8 \\
\hline $\mathrm{O} 1$ & 2.0 & 1.8 & 1.8 & 1.9 & 1.7 & 2.5 & 2.0 & 1.9 & 2.0 & 2.0 & 1.9 \\
\hline Ap & 0.3 & 0.3 & 0.3 & 0.3 & 0.3 & 0.4 & 0.3 & 0.3 & 0.2 & 0.2 & 0.3 \\
\hline
\end{tabular}

A critical factor in distinguishing between partial melting and source inhomogeneity in the petrogenesis of Site 413 basalts is that both basalt units represent fairly high degrees of partial melting; therefore, the incompatible element ratios should reflect the ratios in the mantle source. On this reasoning, there would appear to be considerable geochemical heterogeneity, presumably vertical, beneath Site 413 . However, if the dynamic partial melting model of
Langmuir et al. (1977) is considered, the range of chemical inhomogeneity demanded may be somewhat less than this. Langmuir et al. (1977) proposed that melting at oceanic ridges may take place over a considerable depth range, but with an increasing degree of melting as the mantle diapir rises. Melt can be extracted at any point, but it is suggested that a small proportion of melt always remains in equilibrium with the mantle residue. More extensive 
TABLE 8-Continued

\begin{tabular}{|c|c|c|c|c|c|c|c|c|c|}
\hline $\begin{array}{l}\text { Core-Section } \\
\text { Interval }(\mathrm{cm}) \\
\text { Piece }\end{array}$ & $\begin{array}{c}8-1 \\
35-39 \\
4 \mathrm{~A}\end{array}$ & $\begin{array}{c}9-1 \\
61-63 \\
7\end{array}$ & $\begin{array}{c}10-1 \\
47-50 \\
5\end{array}$ & $\begin{array}{c}11-1 \\
32-35 \\
4\end{array}$ & $\begin{array}{c}13-1 \\
20-25 \\
3\end{array}$ & $\begin{array}{c}13-3 \\
31-36 \\
4\end{array}$ & $\begin{array}{c}14-1 \\
4-14 \\
1\end{array}$ & $\begin{array}{c}14-2 \\
70-80 \\
9\end{array}$ & $\begin{array}{c}14-3 \\
71-75 \\
4 \mathrm{~B}\end{array}$ \\
\hline $\mathrm{SiO}_{2}$ & 50.65 & 50.48 & 50.44 & 49.40 & 50.07 & 50.07 & 50.02 & 50.25 & 50.06 \\
\hline $\mathrm{TiO}_{2}$ & 0.96 & 0.96 & 1.02 & 0.90 & 1.04 & 1.05 & 0.98 & 0.94 & 0.98 \\
\hline $\mathrm{Al}_{2} \mathrm{O}_{3}$ & 14.8 & 15.4 & 14.8 & 14.9 & 14.9 & 15.0 & 14.7 & 14.7 & 14.7 \\
\hline $\mathrm{Fe}_{2} \mathrm{O}_{3}$ & 9.96 & 9.86 & 10.06 & 9.33 & 10.53 & 10.57 & 9.60 & 10.21 & 10.52 \\
\hline $\mathrm{MnO}$ & 0.15 & 0.17 & 0.16 & 0.15 & 0.17 & 0.17 & 0.15 & 0.16 & 0.16 \\
\hline $\mathrm{MgO}$ & 8.61 & 7.38 & 8.13 & 8.97 & 8.02 & 7.87 & 8.44 & 8.05 & 8.06 \\
\hline $\mathrm{CaO}$ & 11.78 & 12.20 & 11.72 & 12.13 & 11.75 & 11.99 & 11.78 & 11.87 & 11.74 \\
\hline $\mathrm{Na}_{2} \mathrm{O}$ & 2.14 & 2.02 & 2.32 & 1.95 & 2.24 & 2.23 & 2.38 & 2.29 & 2.42 \\
\hline $\mathrm{K}_{2} \mathrm{O}$ & 0.15 & 0.22 & 0.11 & 0.11 & 0.08 & 0.06 & 0.18 & 0.13 & 0.11 \\
\hline $\mathrm{P}_{2} \mathrm{O}_{5}$ & 0.127 & 0.088 & 0.125 & 0.092 & 0.110 & 0.106 & 0.137 & 0.118 & 0.119 \\
\hline Total & 99.3 & 98.8 & 98.9 & 97.9 & 99.0 & 99.6 & 98.4 & 98.7 & 98.8 \\
\hline \multicolumn{10}{|c|}{ Trace elements in ppm } \\
\hline $\mathrm{Ni}$ & 65 & 65 & 52 & 73 & 53 & 53 & 71 & 56 & 53 \\
\hline $\mathrm{Cr}$ & 96 & 98 & 71 & 132 & 57 & 65 & 121 & 52 & 38 \\
\hline $\mathrm{Ga}$ & 17 & 15 & 16 & 18 & 16 & 15 & 18 & 16 & 17 \\
\hline $\mathrm{Rb}$ & 3 & 4 & 2 & 1 & 1 & $<1$ & 4 & 2 & 3 \\
\hline $\mathrm{Sr}$ & 116 & 116 & 113 & 108 & 110 & 107 & 114 & 107 & 107 \\
\hline $\mathrm{Y}$ & 21 & 21 & 22 & 19 & 21 & 22 & 22 & 22 & 21 \\
\hline $\mathrm{Zr}$ & 56 & 58 & 65 & 55 & 58 & 57 & 62 & 57 & 58 \\
\hline $\mathrm{Nb}$ & 12 & 13 & 9 & 10 & 11 & 10 & 13 & 12 & 10 \\
\hline $\mathrm{Ba}$ & 65 & 65 & 53 & 52 & 52 & 48 & 64 & 49 & 50 \\
\hline $\mathbf{L a}$ & 6 & 6 & 6 & 5 & 7 & 5 & 6 & 5 & 6 \\
\hline $\mathrm{Ce}$ & 16 & 15 & 16 & 15 & 15 & 18 & 13 & 16 & 17 \\
\hline $\mathrm{Pb}$ & 3 & 4 & 3 & 2 & 5 & 4 & 2 & 3 & 4 \\
\hline Th & $<1$ & 2 & 1 & $<1$ & 2 & 2 & 1 & 3 & 1 \\
\hline $\mathrm{Zn}$ & 65 & 69 & 66 & 61 & 70 & 72 & 67 & 67 & 64 \\
\hline \multicolumn{10}{|c|}{ Selected element ratios } \\
\hline $\mathrm{K} / \mathrm{Rb}$ & 415.0 & 456.6 & 456.6 & 913.1 & 664.1 & - & 373.5 & 539.6 & 304.4 \\
\hline $\mathrm{Rb} / \mathrm{Sr}$ & 0.026 & 0.034 & 0.018 & 0.009 & 0.009 & - & 0.035 & 0.019 & 0.028 \\
\hline $\mathrm{Ba} / \mathrm{Sr}$ & 0.56 & 0.56 & 0.47 & 0.48 & 0.47 & 0.45 & 0.56 & 0.46 & 0.47 \\
\hline $\mathrm{Zr} / \mathrm{Nb}$ & 4.7 & 4.5 & 7.2 & 5.5 & 5.3 & 5.7 & 4.8 & 4.7 & 5.8 \\
\hline $\mathrm{Zr} / \mathrm{Ce}$ & 3.5 & 3.9 & 4.1 & 3.7 & 3.9 & 3.2 & 4.8 & 3.6 & 3.4 \\
\hline $\mathrm{Zr} / \mathrm{Y}$ & 2.7 & 2.8 & 3.0 & 2.9 & 2.8 & 2.6 & 2.8 & 2.6 & 2.8 \\
\hline $\mathrm{Ce}_{\mathrm{N}} / \mathrm{Y}_{\mathrm{N}}$ & 1.86 & 1.75 & 1.78 & 1.93 & 1.75 & 2.00 & 1.44 & 1.78 & 1.98 \\
\hline $\mathrm{tFe} / \mathrm{Mg}$ & 1.3 & 1.5 & 1.4 & 1.2 & 1.5 & 1.6 & 1.3 & 1.5 & 1.5 \\
\hline \multicolumn{10}{|l|}{ C.I.P.W. Norm } \\
\hline $\mathrm{Q}$ & 0.3 & 1.5 & 0.1 & 0.0 & 0.0 & 0.3 & 0.0 & 0.0 & 0.0 \\
\hline Or & 0.9 & 1.3 & 0.7 & 0.7 & 0.5 & 0.4 & 1.1 & 0.8 & 0.7 \\
\hline $\mathrm{Ab}$ & 18.4 & 17.4 & 20.0 & 17.0 & 19.3 & 19.1 & 20.6 & 19.8 & 20.9 \\
\hline An & 30.8 & 33.1 & 30.3 & 32.5 & 31.1 & 31.3 & 29.8 & 30.1 & 29.4 \\
\hline $\mathrm{Ne}$ & 0.0 & 0.0 & 0.0 & 0.0 & 0.0 & 0.0 & 0.0 & 0.0 & 0.0 \\
\hline $\mathrm{Di}$ & 22.5 & 23.0 & 23.0 & 23.4 & 22.6 & 23.1 & 23.7 & 23.9 & 23.9 \\
\hline Hy & 23.2 & 19.9 & 21.9 & 221.1 & 22.1 & 21.6 & 17.8 & 20.9 & 18.4 \\
\hline AlM & 0.0 & 0.0 & 0.0 & 1.6 & 0.3 & 0.0 & 3.0 & 0.6 & 2.7 \\
\hline Mt & 1.8 & 1.7 & 1.8 & 1.7 & 1.9 & 1.9 & 1.7 & 1.8 & 1.9 \\
\hline $\mathrm{Ol}$ & 1.9 & 1.9 & 2.0 & 1.8 & 2.0 & 2.0 & 1.9 & 1.8 & 1.9 \\
\hline Ap & 0.3 & 0.2 & 0.3 & 0.2 & 0.3 & 0.3 & 0.3 & 0.3 & 0.3 \\
\hline
\end{tabular}

melting of mantle which has already yielded up an earlier liquid fraction at greater depth may thus produce magmas with much lower incompatible element concentrations and higher compatible-/incompatible-element ratios. The lower unit at Site 413 would be a good candidate for such a magma, in that the incompatible element levels are the lowest of any basalt recovered on Leg 49, and compatible/incompatible element ratios are abnormally high. For instance, $\mathrm{Zr} / \mathrm{Y}$ ratios for this unit (about 1.7) are unusually low (below chondritic $\sim 2.8$ ), and similar to the ratios in other basalts from the FAMOUS area regarded by Langmuir et al. (1977) as having been produced by this mechanism. The model allows the production of basalts with "MORB-like", chemistry from more fertile 
TABLE 9

Analyses of Basalts From Hole 413, Leg 49

\begin{tabular}{|c|c|c|c|c|}
\hline $\begin{array}{l}\text { Core-Section } \\
\text { Interval }(\mathrm{cm}) \\
\text { Piece }\end{array}$ & $\begin{array}{c}1-2 \\
114-116 \\
13\end{array}$ & $\begin{array}{c}2-1 \\
41-43 \\
5\end{array}$ & $\begin{array}{c}4-1 \\
6-8 \\
1\end{array}$ & $\begin{array}{c}5-1 \\
9-11 \\
2\end{array}$ \\
\hline $\mathrm{SiO}_{2}$ & 48.1 & 48.3 & 46.6 & 47.3 \\
\hline $\mathrm{TiO}_{2}$ & 1.33 & 1.44 & 0.67 & 0.66 \\
\hline $\mathrm{Al}_{2} \mathrm{O}_{3}$ & 14.7 & 14.7 & 16.1 & 15.3 \\
\hline $\mathrm{Fe}_{2} \mathrm{O}_{3}$ & 10.20 & 10.37 & 11.76 & 11.53 \\
\hline $\mathrm{MnO}$ & - & - & - & - \\
\hline $\mathrm{MgO}$ & 9.94 & 9.78 & 9.42 & 10.81 \\
\hline $\mathrm{CaO}$ & 11.15 & 11.06 & 11.68 & 11.11 \\
\hline $\mathrm{Na}_{2} \mathrm{O}$ & 2.67 & 2.98 & 2.53 & 2.72 \\
\hline $\mathrm{K}_{2} \mathrm{O}$ & 0.47 & 0.47 & 0.09 & 0.12 \\
\hline $\mathrm{P}_{2} \mathrm{O}_{5}$ & 0.21 & 0.24 & 0.060 & 0.040 \\
\hline Total & 98.8 & 99.3 & 98.9 & 99.6 \\
\hline \multicolumn{5}{|c|}{ Trace elements in ppm } \\
\hline $\mathrm{Ni}$ & 277 & 248 & 301 & 354 \\
\hline $\mathrm{Cr}$ & 708 & 610 & 553 & 580 \\
\hline $\mathrm{Ga}$ & 14 & 16 & 15 & 16 \\
\hline $\mathrm{Rb}$ & 6 & 5 & $<1$ & $<1$ \\
\hline $\mathrm{Sr}$ & 234 & 246 & 74 & 75 \\
\hline $\mathrm{Y}$ & 22 & 23 & 20 & 19 \\
\hline $\mathrm{Zr}$ & 102 & 112 & 34 & 33 \\
\hline $\mathrm{Nb}$ & 25 & 25 & 4 & 5 \\
\hline $\mathrm{Ba}$ & 124 & 147 & 15 & 12 \\
\hline $\mathrm{La}$ & 15 & 16 & 3 & 4 \\
\hline $\mathrm{Ce}$ & 31 & 35 & 3 & 5 \\
\hline $\mathrm{Pb}$ & 3 & 4 & 4 & 5 \\
\hline Th & 3 & 1 & $<1$ & 2 \\
\hline $\mathrm{Zn}$ & 67 & 69 & 64 & 64 \\
\hline \multicolumn{5}{|c|}{ Selected element ratios } \\
\hline $\mathrm{K} / \mathrm{Rb}$ & 650.2 & 780.3 & $>747$ & $>996$ \\
\hline $\mathrm{Rb} / \mathrm{Sr}$ & 0.026 & 0.020 & $<0.014$ & $<0.013$ \\
\hline $\mathrm{Ba} / \mathrm{Sr}$ & 0.53 & 0.60 & 0.20 & 0.16 \\
\hline $\mathrm{Zr} / \mathrm{Nb}$ & 4.1 & 4.5 & 8.4 & 6.6 \\
\hline $\mathrm{Zr} / \mathrm{Ce}$ & 3.3 & 3.2 & 2.8 & 3.0 \\
\hline $\mathrm{Zr} / \mathrm{Y}$ & 4.6 & 4.9 & 1.7 & 1.7 \\
\hline $\mathrm{Ce}_{\mathrm{N}} / \mathrm{Y}_{\mathrm{N}}$ & 3.44 & 3.72 & 1.47 & 1.41 \\
\hline $\mathrm{tFe} / \mathrm{Mg}$ & 1.2 & 1.2 & 1.4 & 1.2 \\
\hline \multicolumn{5}{|l|}{ C.I.P.W. Norm } \\
\hline $\mathrm{Q}$ & 0.0 & 0.0 & 0.0 & 0.0 \\
\hline Or & 2.8 & 2.8 & 0.5 & 0.7 \\
\hline $\mathrm{Ab}$ & 23.0 & 23.8 & 19.6 & 20.5 \\
\hline An & 27.3 & 25.7 & 33.0 & 29.6 \\
\hline $\mathrm{Ne}$ & 0.0 & 1.0 & 1.2 & 1.5 \\
\hline $\mathrm{Di}$ & 22.5 & 23.0 & 21.0 & 21.1 \\
\hline Hy & 1.2 & 0.0 & 0.0 & 0.0 \\
\hline $\mathrm{Ol}$ & 18.1 & 18.4 & 21.0 & 23.1 \\
\hline $\mathrm{Mt}$ & 1.8 & 1.8 & 21. & 2.0 \\
\hline Il & 2.6 & 2.8 & 1.3 & 1.3 \\
\hline Ap & 0.5 & 0.6 & 0.1 & 0.1 \\
\hline
\end{tabular}

"undepleted" mantle, but these should normally be accompanied by basalts with more "enriched" geochemical characteristics. Both types certainly occur at Site 413 (with intermediate members at Sites 411 and 412 also), but whether the whole range of basalt types can be explained by this mechanism, as opposed to some degree of source inhomogeneity, is really dependent on additional isotopic constraints.

Incompatible-element ratios for basalts from FAMOUS Sites 411, 412, and 413 (Tables 7 and 9) are rather similar to those in basalts from $45^{\circ} \mathrm{N}$. To emphasize these data, points for the two areas have been plotted on the same diagrams. FAMOUS basalts, like those from $45^{\circ} \mathrm{N}$, have higher $\mathrm{Sr} / \mathrm{Zr}$ (Figure 31), Ba/Zr (Figure 30), Ce/Zr (Figure 32), $\mathrm{La} / \mathrm{Zr}$, and $\mathrm{Nb} / \mathrm{Zr}$ (Figure 24) ratios than Reykjanes basalts. On the other hand, $\mathrm{P}_{2} \mathrm{O}_{5} / \mathrm{Zr}$ ratios are similar in all Leg 49 basalts (Figure 23). Contrasting with this $\mathrm{TiO}_{2} / \mathrm{Zr}$ and especially with $\mathrm{Y} / \mathrm{Zr}$, ratios are higher (Figures 36 and 33) than in both Reykjanes and $45^{\circ} \mathrm{N}$ basalts. The higher $\mathrm{Y} / \mathrm{Zr}$ ratios more than compensate for the higher $\mathrm{Ce} / \mathrm{Zr}$ ratios, with the result that chondrite-normalized $\mathrm{Ce} / \mathrm{Y}$ ratios for basalts from Sites 411 and 412 are low (Figure 34), indicating that REE distributions are close to chondritic.

It is possible, of course, that $\mathrm{Zr}$-normalized ratios for the FAMOUS basalts are higher simply because $\mathrm{Zr}$ is deficient. Similar arguments might apply to $45^{\circ} \mathrm{N}$ basalts, too. However, since $\mathrm{P}_{2} \mathrm{O}_{5}$ follows $\mathrm{Zr}$ closely in all Leg 49 basalts, this would necessitate a comparable deficiency in phosphorous. Moreover, $45^{\circ} \mathrm{N}$ basalts already have unusually low $\mathrm{Y} / \mathrm{Zr}$ and $\mathrm{Ti} / \mathrm{Zr}$ ratios, a feature which would be magnified if $\mathrm{Zr}$ were regarded as deficient at $45^{\circ} \mathrm{N}$. Regional differences between other incompatible/ compatible-element ratios would still exist, even allowing for deficiency or otherwise in $\mathrm{Zr}$.

Although FAMOUS and $45^{\circ} \mathrm{N}$ basalts have similar incompatible-element ratios, there is very little overlap in the absolute concentrations of trace elements between the two groups. Only two samples from Site 413 in fact reach into the range of $45^{\circ} \mathrm{N}$ samples. Some samples from the median valley at $45^{\circ} \mathrm{N}$ (Erlank and Kable, 1976) have lower concentrations of incompatible elements than Site 410 samples (Figures 30 and 24), but the restricted range of incompatible-element concentrations in the FAMOUS area is apparent also from Leg 37 data (Aumento, Melson, et al., 1977). This suggests that total levels of incompatible elements are different in the mantle sources of the two areas, although element ratios are similar. A plot of $\mathrm{Fe} / \mathrm{Mg}$ ratio against $\mathrm{Zr}$, for instance (Figure 38 ) shows only a weak correlation, which could support this suggestion. (On the other hand, observed $\mathrm{Fe} / \mathrm{Mg}$ ratios in basalts are dependent upon a number of factors as well as the degree of partial melting: e.g., $\mathrm{pH}_{2} \mathrm{O}, \mathrm{pO}_{2}$, depth of melting, nature of mantle mineral phases, secondary alteration.)

Basalts recovered on Leg 37 (e.g., Aumento, Melson, et al., 1977; Lambert and Holland, 1977; Bryan and Thompson, 1977) are very similar geochemically to those described here, but with the larger yield of samples recovered, show a larger range of composition. With the large number of laboratories involved in the study of Leg 37 samples too, there is greater scatter in the data and it is more difficult to discern consistent trace element trends. One interesting feature is apparent, though. Most of the FAMOUS samples recovered on Leg 37 have less than 1.4 per cent $\mathrm{TiO}_{2}$ and less than $30 \mathrm{ppm}$ Y. Yet a number of more evolved samples with $\mathrm{Zr}$ levels between 60 and almost 120 ppm (Holes 332A and 335) show no comparable 


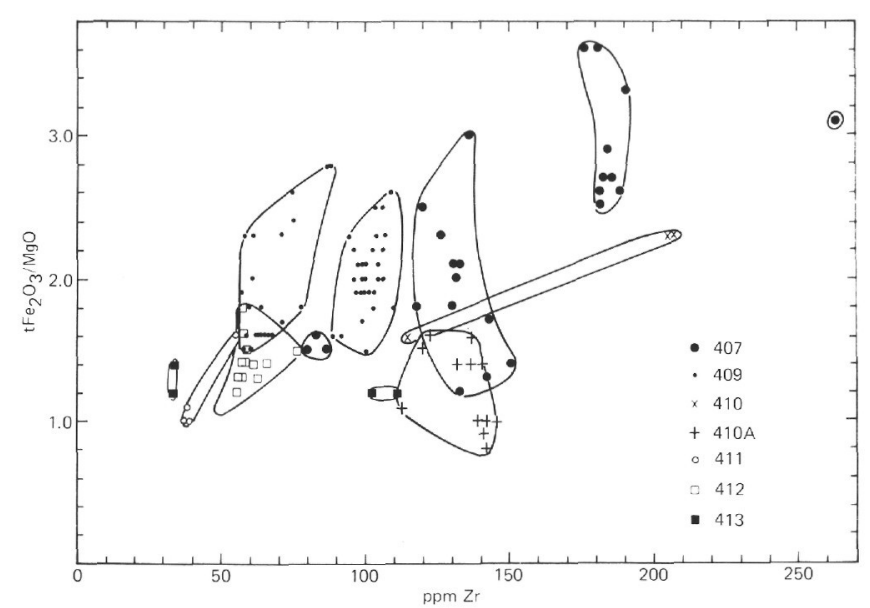

Figure 38. $t \mathrm{Fe} / \mathrm{Mg}$ versus $\mathrm{Zr}$ for Leg 49 basalts (for clarity, Site 408 data omitted).

increase in either $\mathrm{TiO}_{2}$ or $\mathrm{Y}$. This feature is similar to that observed at $45^{\circ} \mathrm{N}$. Conversely, a number of more primitive samples from the Hudson Cruise at $45^{\circ} \mathrm{N}$, analyzed by Aumento (1968) and Erlank and Kable (1976), plot among the FAMOUS data on $\mathrm{TiO}_{2}$ versus $\mathrm{Zr}$ and $\mathrm{Y}$ versus $\mathrm{Zr}$ plots (Figures 39 and 40). There is an implication, therefore, that both titanium and yttrium are being retained in the mantle source at both FAMOUS and $45^{\circ} \mathrm{N}$ sites, at lower degrees of partial melting.

The reason for variable Ti retention in the source of ocean basalts, which thus limits $\mathrm{TiO}_{2}$ in the erupted basalts, is not clear. Suites of basalts from various areas generally show a curved relationship between $\mathrm{TiO}_{2}$ and $\mathrm{Zr}$; but the $\mathrm{TiO}_{2}$ level attained in each area is different (Figure 41). Nisbet and Pearce (1973) noted a broad positive correlation between $\mathrm{TiO}_{2}$ content of basalts and spreading rate. Although the wide range of $\mathrm{TiO}_{2}$ contents observed in one hole (Site 407) would appear to negate this, it is apparent that partial melting processes (in the North Atlantic regions studied) can limit the $\mathrm{TiO}_{2}$ content of the generated liquids owing to retention of $\mathrm{TiO}_{2}$ in the source. On the other hand, fractional crystallization processes operating in sub-axis magma chambers could appreciably enhance the $\mathrm{TiO}_{2}$ content of residual magmas, because of the separation of Ti-poor phases such as olivine, pyroxenes, and plagioclase. It may be significant that most of the basaltic units at Leg 49 sites appear to be essentially partial melt compositions, with only limited evidence of superimposed fractional crystallization. Slow-spreading ridges like the North Atlantic Ridge may thus have only limited development of sub-axis magma chambers. Fast-spreading ridges, on the other hand, might have better developed magma chambers, with consequently a greater chance of developing $\mathrm{TiO}_{2}$-rich residual magmas through fractional crystallization. This would explain, at least qualitatively, Nisbet's and Pearce's (1973) observations.

\section{REGIONAL COMPARISONS: MANTLE HETEROGENEITY IN THE NORTH ATLANTIC}

Leg 49 data have demonstrated two main points: (a) that there is a remarkable consistency in the geochemical characteristics of basalts erupted at a particular ridge

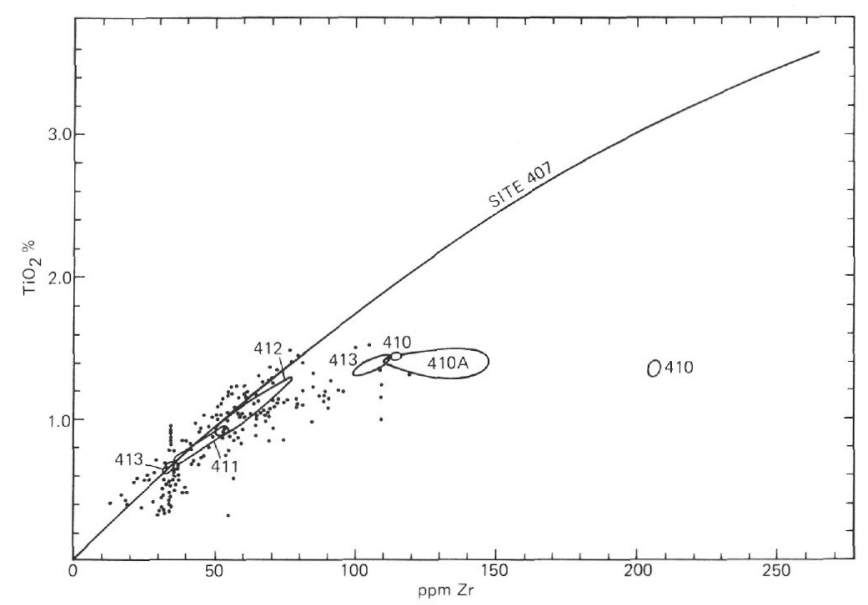

Figure 39. $\mathrm{TiO}_{2}$ versus $\mathrm{Zr}$ for FAMOUS sites (Leg 37). Fields for $45^{\circ} \mathrm{N}$ and FAMOUS sites (this study) shown for comparison.

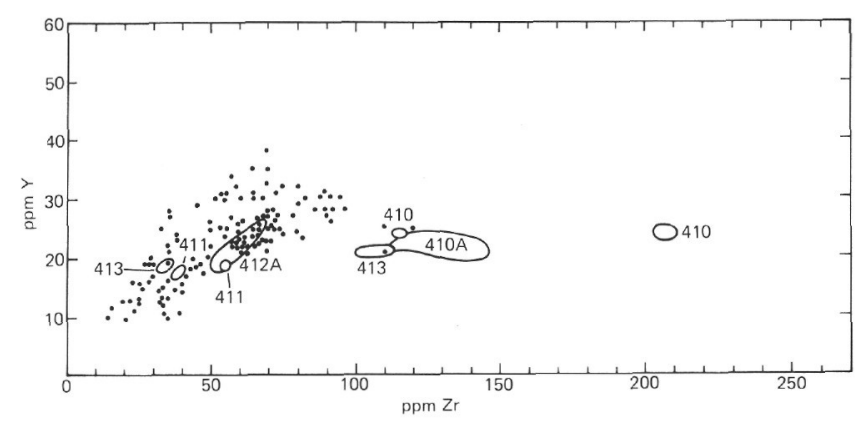

Figure 40. $Y$ versus $Z r$ for FAMOUS sites (Leg 37). Fields for $45^{\circ} \mathrm{N}$ and FAMOUS sites (this study) shown for comparison.

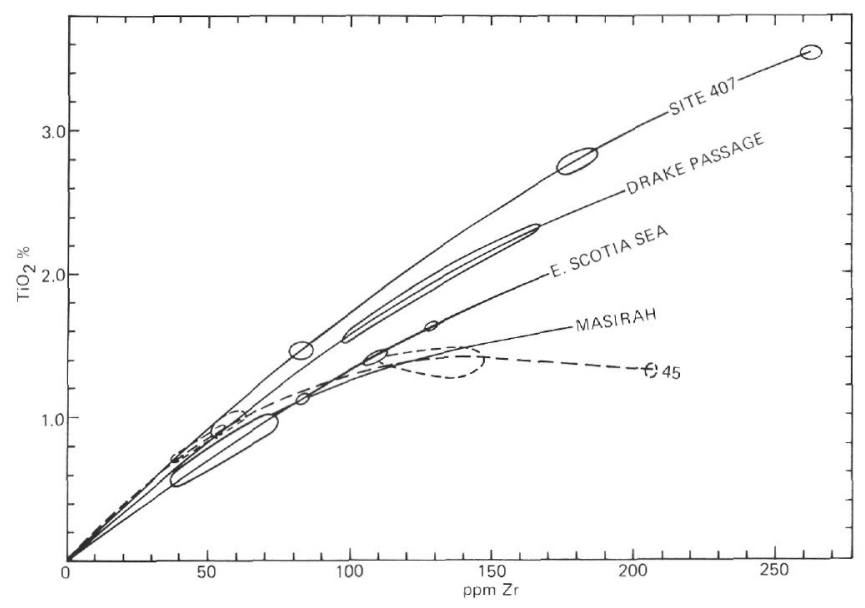

Figure 41. $\mathrm{TiO}_{2}$ versus $\mathrm{Zr}$ relationships in ocean basalts.

segment for periods in excess of $30 \mathrm{~m} . \mathrm{y}$. , and (b) that there are significant differences in basalt compositions along the Mid-Atlantic Ridge, particularly with regard to incompatible-element levels and ratios. It would appear extremely unlikely, for instance, that a basalt with 
Reykjanes geochemistry could ever be erupted at $45^{\circ} \mathrm{N}$ or $36^{\circ} \mathrm{N}$, or vice versa. In summarizing regional variations, we will make use of three main diagrams: (a) $\mathrm{Ce}$ versus $\mathrm{Zr}$ (Figure 42), of significance with regard to REE behavior; (b) $\mathrm{Ba}$ versus $\mathrm{Zr}$ (Figure 30), which, because of the close affinity of $\mathrm{Ba}, \mathrm{K}$, and $\mathrm{Rb}$, has significance with regard to $\mathrm{K}$ and $\mathrm{Rb}$ also, and (c) $\mathrm{Nb}$ versus $\mathrm{Zr}$ (Figure 29) which has significance with regard to other highly incompatible elements, such as $\mathrm{Ta}$ and $\mathrm{Th}$.

\section{Ce Versus Zr}

It is apparent from Figure 42 that there are quite large differences in $\mathrm{Ce} / \mathrm{Zr}$ ratios in oceanic basalts from different regions. Basalts from the Nazca plate, Leg 34 (Rhodes et al., 1976; Thompson et al., 1976), have consistently low $\mathrm{Ce} / \mathrm{Zr}$ ratios, and of course have uniformly light-RE depleted REE patterns. Basalts from the Scotia Sea all lie on a smooth curve with higher $\mathrm{Ce} / \mathrm{Zr}$ ratio, but in fact come from two different areas in the Scotia Sea many hundreds of kilometers apart: the South Sandwich Spreading Center in the East Scotia Sea (Tarney et al., 1977; Saunders and Tarney, in press; Saunders, Tarney, Weaver, and Barker, in press) and the volcanoes of Bridgeman and Deception islands situated on the axis of back-arc spreading in Bransfield Strait, West Scotia Sea (Tarney et al., 1977; Weaver et al., in preparation). Scotia Sea REE patterns vary from flat to slightly light-RE enriched. Basalts from the Sarmiento ophiolite complex in southern Chile, another back-arc marginal basin (Dalziel et al., 1974; Tarney et al., 1977; Saunders, Tarney, Stern, and Dalziel, in press), have higher $\mathrm{Ce} / \mathrm{Zr}$ ratios and rather more fractionated $\mathrm{REE}$

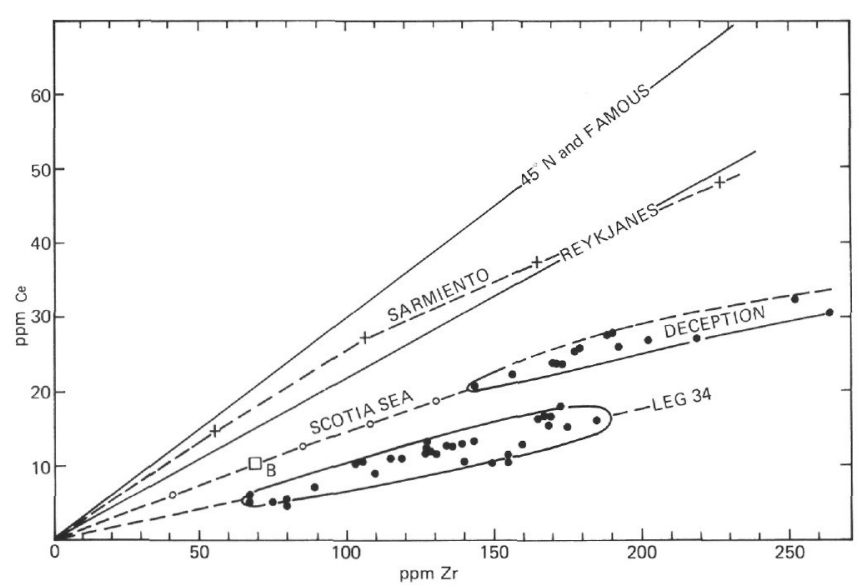

Figure 42. Ce versus $Z$ r relationships in ocean floor basalts from different regions. Correlation lines for FAMOUS, $45^{\circ} \mathrm{N}$, and for Reykjanes basalts from Figures 25 and 32 (this study). Data for Sarmiento ophiolite complex, S. Chile, from Saunders, Tarney, et al. (in press). Nazca Plate data from Rhodes et al. (1976) and Thompson et al. (1976). Data for the Scotia Sea region from Tarney et al. (1977) for basalts from the S. Sandwich Spreading Center, and from Tarney et al. (1977) and Weaver et al. (in preparation) for Bransfield Strait marginal basin volcanics (Deception and Bridgeman islands). patterns. The slight curvature in the Sarmiento data and the Deception data results from fractional crystallization processes. Ratio lines for Reykjanes, $45^{\circ} \mathrm{N}$, and FAMOUS basalts are from the present data. It is clear that all North Atlantic basalts sampled on Leg 49 are geochemically very different from "typical MORB," with the possible exception of the lower unit at Site 413.

Using $\mathrm{Zr}$-normalized data for $\mathrm{Ce}$ and $\mathrm{Y}$, it is apparent that observed $\mathrm{Ce} / \mathrm{Y}$ ratio patterns in oceanic basalts are a function of four factors: (a) regional variations in the $\mathrm{Ce}$ concentration of the source, (b) similar variations in Y, (c) degree of partial melting with variable retention of $Y$ in the source, and (d) minor effects attributable to fractional crystallization in magma chambers. Thus, it is inadvisable to take the observed basalt REE patterns as directly indicative of the REE distributions in the mantle source. Other more complex melting processes (Langmuir et al., 1977) may also contribute to observed variations in basalt REE patterns and in other compatible/incompatible-element ratios, as noted earlier.

\section{Ba Versus Zr}

Major differences in $\mathrm{Ba} / \mathrm{Zr}$ ratio in basalts from different regions are also apparent from Figure 30. It is clear that all North-Atlantic basalts sampled on Leg 49 are very different from "MORB" type basalts from the Nazca Plate, which have very low $\mathrm{Ba} / \mathrm{Zr}$ ratios. It is likely that similar differences would occur for $\mathrm{K} / \mathrm{Zr}$ and $\mathrm{Rb} / \mathrm{Zr}$ ratios (see Erlank and Kable, 1976). Indeed, allowing for the effects of alteration on $\mathrm{K}$ and $\mathrm{Rb}$ distributions, it is apparent that both $\mathrm{K}$ and $\mathrm{Rb}$ vary sympathetically with $\mathrm{Ba}$. The very large difference in $\mathrm{Ba}$ abundances between the most fractionated $45^{\circ} \mathrm{N}$ basalts and the most fractionated basalts from the Nazca Plate is striking, and strongly suggests that at $45^{\circ} \mathrm{N}$ there is an additional mantle phase, such as phlogopite, holding $\mathrm{K}, \mathrm{Rb}$, and $\mathrm{Ba}$. Early breakdown of phlogopite at low degrees of partial melting (cf. Modreski and Boettcher, 1972), and at depths consistent with the generation of alkalic basalts, could account for the very high $\mathrm{Ba} / \mathrm{Zr}$ ratios in $45^{\circ} \mathrm{N}$ basalts. By contrast, there is no suggestion of phlogopite in the source of Nazca Plate Leg 34 basalts. The Reykjanes basalts have intermediate $\mathrm{Ba} / \mathrm{Zr}$ ratios, but there is no indication of a pattern of melting behavior similar to that at $45^{\circ} \mathrm{N}$. This may mean that $\mathrm{Ba}$ is held in an alternative mantle phase, such as hornblende (Kesson and Price, 1972) or clinopyroxene.

\section{Nb Versus Zr}

There are marked differences in the observed $\mathrm{Zr} / \mathrm{Nb}$ ratios of basalts from different regions (Figure 24). In the Reykjanes basalts and probably in the Nazca Plate basalts, the ratio appears to be constant, within the limits of precision of the analytical technique, and the correlation line passes through the origin. At $45^{\circ} \mathrm{N}$, however, there is a linear correlation between $\mathrm{Nb}$ and $\mathrm{Zr}$, but the correlation line intersects the $\mathrm{Zr}$ axis. As a result, the $\mathrm{Zr} / \mathrm{Nb}$ ratio increases with decreasing $\mathrm{Zr}$, particularly at low $\mathrm{Zr}$ values. Most of the FAMOUS area basalts lie on a correlation line through zero, apart from the lower unit at Site 413, which, 
if included, would cause the correlation line to intercept the $\mathrm{Zr}$ axis also. It is clear that $\mathrm{Zr} / \mathrm{Nb}$ ratios in the FAMOUS area basalts are similar to those in basalts from $45^{\circ} \mathrm{N}$, but the $\mathrm{Zr}-\mathrm{Nb}$ relationship, as well as the ratio, differs from that in the Reykjanes basalts. This can be illustrated by plotting $\mathrm{Zr} / \mathrm{Nb}$ against $\mathrm{CeN}_{\mathrm{N}} / \mathrm{Y}_{\mathrm{N}}$ (Figure 43), where a clear linear correlation emerges for the $45^{\circ} \mathrm{N}$ and FAMOUS area samples, but there is no significant correlation between these two ratios in the Reykjanes basalts. Given that the pair $\mathrm{Nb}-\mathrm{Zr}$ act in a more incompatible fashion than $\mathrm{Ce}-\mathrm{Y}$, it might be argued that $\mathrm{Zr} / \mathrm{Nb}$ ratios should not change appreciably with varying degrees of partial melting, although $\mathrm{Ce} / \mathrm{Y}$ ratios would. Where $\mathrm{Zr} / \mathrm{Nb}$ varies sympathetically with $\mathrm{Ce} / \mathrm{Y}$, however, it would be necessary to invoke an additional mineral phase controlling $\mathrm{Zr} / \mathrm{Nb}$ behavior during partial melting, or to postulate depth-related inhomogeneity in the mantle source. Choosing between these different possibilities is difficult without isotopic constraints.

Although in broad terms there is a correlation between $\mathrm{Ce} / \mathrm{Zr}, \mathrm{Ba} / \mathrm{Zr}$, and $\mathrm{Nb} / \mathrm{Zr}$ ratios in the basalts from different regions, in detail this is not so. For instance, while basalts from the Scotia Sea region have similar Ce/ $\mathrm{Zr}$ ratios, those in Bransfield Strait have much higher $\mathrm{Ba} / \mathrm{Zr}$ and lower $\mathrm{Nb} / \mathrm{Zr}$ ratios than basalts from the East Scotia Sea (Tarney et al., 1977). A Nb versus Ce plot for Leg 49 basalts (Figure 44) still distinguishes Reykjanes from $45^{\circ} \mathrm{N}$ and FAMOUS area samples, as does a $\mathrm{Ba}$ versus $\mathrm{Ce}$ plot. On the other hand, $\mathrm{Ba}$ and $\mathrm{Nb}$ show more coherent behavior in Leg 49 and Leg 34 basalts (though the relationship is not linear). Note that the more highly charged incompatible elements $\mathrm{Zr}$ and $P$ show coherent behavior in Leg 49 basalts also. It is apparent that if incompatible element ratios reflect the ratios in the mantle source, it is not simply a mixing of a uniformly "depleted" and a uniformly "enriched" source which is controlling the chemistry of intermediate members. Rather, each segment of mantle appears to have its own characteristic incompatible-element ratios. In particular, the linear Reykjanes trend on plots such as $\mathrm{Ce}-\mathrm{Zr}, \mathrm{Ba}-\mathrm{Zr}$, and $\mathrm{Nb}-\mathrm{Zr}$ cannot be accounted for by mixing a depleted Nazca plate-like source with an enriched $45^{\circ} \mathrm{N}$-type source.

It is important to note from these diagrams that the range of $\mathrm{Zr}$ abundances is approximately the same as basalts from different regions (e.g., Reykjanes, $45^{\circ} \mathrm{N}$, Scotia Sea, Nazca Plate), no matter whether the basalts erupted have "enriched" characeristics (as at $45^{\circ} \mathrm{N}$ ) or "depleted" characteristics (Nazca Plate). Thus, there is no reason to suspect gross differences in $\mathrm{Zr}$ concentrations in the mantle sources in various regions. The marked differences in $\mathrm{Ce} / \mathrm{Zr}, \mathrm{Ba} / \mathrm{Zr}$, and $\mathrm{Nb} / \mathrm{Zr}$ ratios observed seem to depend more directly on the $\mathrm{Ce}, \mathrm{Ba}$, and $\mathrm{Nb}$ levels in the mantle source.

In summary, it is apparent that basalts with similar trace-element characteristics can be erupted at a particular ridge segment for periods in excess of $35 \mathrm{~m}$.y. However, systematic differences in the chemistry of basalts erupted at different sections of the Mid-Atlantic Ridge strongly support previous suggestions of regional heterogeneity in the mantle source of these basalts in the North Atlantic region. At the same time, the data cast doubt on mixing of magmas or mantle sources as a dominant process

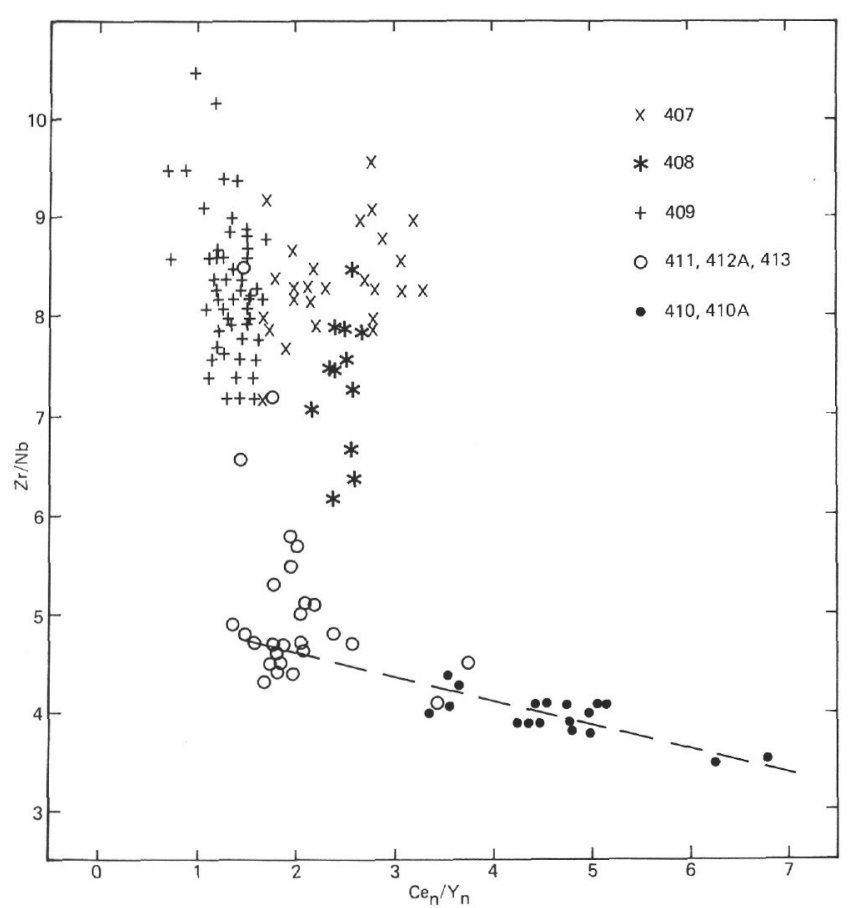

Figure 43. Plot of $\mathrm{Zr} / \mathrm{Nb}$ versus $\mathrm{Ce}_{N} / Y_{N}$ for Leg 49 basalts.

controlling trace element levels or ratios. There may be some local (vertical) heterogeneity superimposed upon the regional heterogeneity, but the extent of this is difficult to assess precisely in the absence of isotopic constraints. The data offer little support for the existence of " geochemical", mantle plumes connected only with bathymetric highs such as Iceland and the Azores: basalts from $45^{\circ} \mathrm{N}$ and $37^{\circ} \mathrm{N}$, for instance, situated well to the north and south of the Azores, have "enriched" trace-element concentrations and remarkably similar trace element ratios, but lie at bathymetrically normal segments of the ridge.

The data do, however, pose new problems concerning the mechanism by which heterogeneity is established. Many incompatible-element ratios are apparently unaffected by the processes of crystal-liquid equilibria involved in generating basalts, and even depth-related parameters (e.g., normative compositions, $\mathrm{Ce} / \mathrm{Y}$ ratios) may be associated with no change in these ratios. What then causes the ratios to vary? Here one can only speculate. On the one hand it may be that at greater depths mineral phases such as garnet, or other high-pressure mantle phases, can fractionate these elements more efficiently. The efficiency of garnet in fractionating REE is well known. But the garnet structure will also take in elements such as $\mathrm{Zr}$ and $\mathrm{Ti}$ in quite high proportions in some circumstances (Dowty, 1971; Huggins et al., 1977). Such processes may operate over very long periods of time at very low degrees of partial melting, with the result that very small differences in bulk distribution coefficient are accentuated. Another possibility is that the processes of crustal extraction operating since the early Archaean can lead to significant removal of selected trace elements from the mantle. Element ratios such as $\mathrm{Ce} / \mathrm{Zr}$, $\mathrm{Rb} / \mathrm{Zr}, \mathrm{K} / \mathrm{Zr}, \mathrm{Ba} / \mathrm{Zr}, \mathrm{Ce} / \mathrm{Y}, \mathrm{Ce} / \mathrm{Ti}, \mathrm{Ba} / \mathrm{Ti}, \mathrm{Ce} / \mathrm{P}, \mathrm{Ba} / \mathrm{P}$ are much higher in the continental crust than in oceanic basalts, suggesting that although highly charged elements such as 


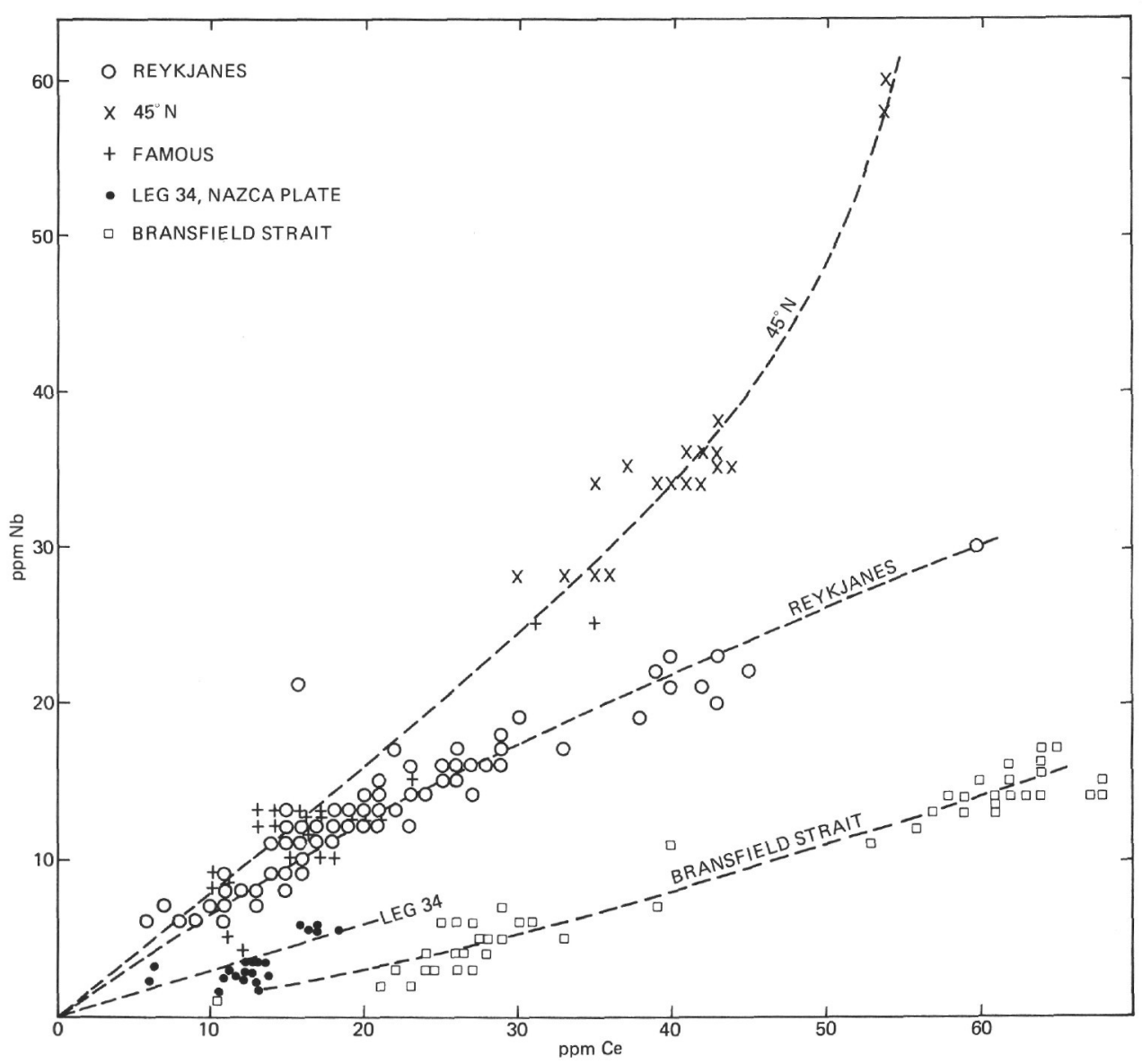

Figure 44. $\mathrm{Nb}$ versus Ce for Leg 49 basalts. For comparison, data from Leg 34 (Nazca Plate) and Bransfield Strait marginal basin volcanics also included. See Figure 42 for data sources.

$\mathrm{Zr}, \mathrm{Ti}$, and $\mathrm{P}$ act incompatibly in basaltic suites, they behave in a much more compatible fashion in the subduction zone environments where continental material is generated.

Finally, none of the oceanic basalts sampled on Leg 49 has the chemical characteristics of "MORB." In view of the widespread use of discrimination diagrams, such as those of Pearce and Cann (1973), in characterizing basalt magma types according to their tectonic environment, we reproduce in Figure 45 a plot of Leg 49 basalts on the Ti-Zr-Y diagram of Pearce and Cann. Points for each unit plot in closely defined fields, but many fall outside the limits of the field for mid-ocean ridge basalts, especially samples from $45^{\circ} \mathrm{N}$.

\section{REFERENCES}

Arth, J.G. and Barker, F., 1977. Rare-earth partitioning between hornblende and dacitic liquid and implications for the genesis of trondhjemitictonalitic magmas, Geology, v. 4, p. 534-536.

Aumento, F., 1968. The Mid-Atlantic Ridge near $45^{\circ} \mathrm{N}$. II. Basalts from the area of Confederation Peak, Canadian J. Earth Sci. v. 5, p. 1-21.

Aumento, F., 1971. Uranium content of mid-oceanic basalts, Earth Planet. Sci. Lett., v. 11, p. 90-94.

Aumento, F. and Hyndman, R.D., 1971. Uranium content of the oceanic upper mantle, Earth Planet. Sci. Lett., v. 12, p. 373-384.
Aumento, F., Loncarevic, B.D., and Ross, D.I., 1971. Hudson Geotraverse: geology of the Mid-Atlantic Ridge at $45^{\circ} \mathrm{N}$, Phil. Trans. Roy. Soc. London, v. 268A, p. 623-650.

Aumento, F., Melson, W.G., et al., 1977. Initial Reports of the Deep Sea Drilling Project, v. 37: Washington (U.S. Government Printing Office).

Basu, A.R. and Murthy, V.R., 1977. Kaersutites, suboceanic low-velocity zone and the origin of mid-oceanic ridge basalts, Geology, v. 5, p. 365-368.

Bennett, H. and Oliver, G.J., 1976. Development of fluxes for the analysis of ceramic materials by $\mathrm{X}$-ray fluorescence spectrometry, Analyst, v. 101, p. 803-807.

Bryan, W.B. and Thompson, G., 1977. Basalts from DSDP Leg 37 and the FAMOUS area: compositional and petrogenetic comparisons, Canadian J. Earth Sci., v. 14, p. 875-885.

Cann, J.R. and Heath, R., 1976. Some trace elements in basalts from Leg 34. In Hart, S.R., Yeats, R.S., et al., Initial Reports of the Deep Sea Drilling Project, v. 34: Washington (U.S. Government Printing Office), p. 289-292.

Dalziel, I.W.D., de Wit, M.J., and Palmer, K.F., 1974. Fossil marginal basin in the southern Andes, Nature, London, v. 250, p. 291-294.

Dowty, E., 1971. Crystal chemistry of titanian and zirconian garnet: I Review and spectral studies, Am. Mineral., v. 56, p. 1983-2009.

Erlank, A.J. and Kable, E.J.D., 1976. The significance of incompatible elements in Mid-Atlantic Ridge basalts from $45^{\circ} \mathrm{N}$ with particular reference to $\mathrm{Zr} / \mathrm{Nb}$, Contrib. Mineral. Petrol., v. 54, p. 281-291. 

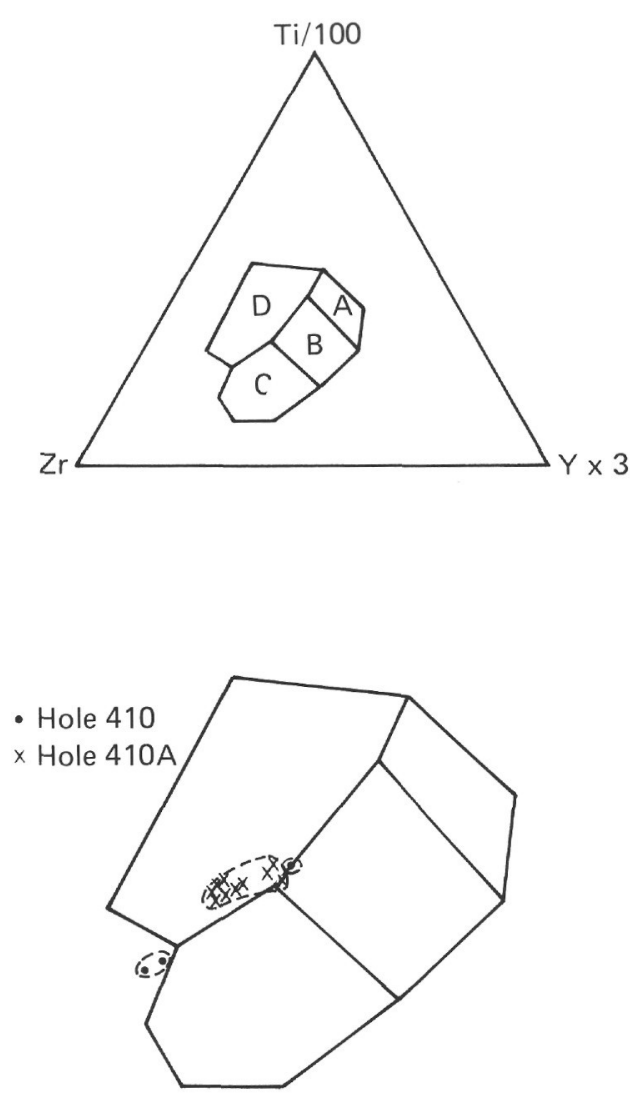
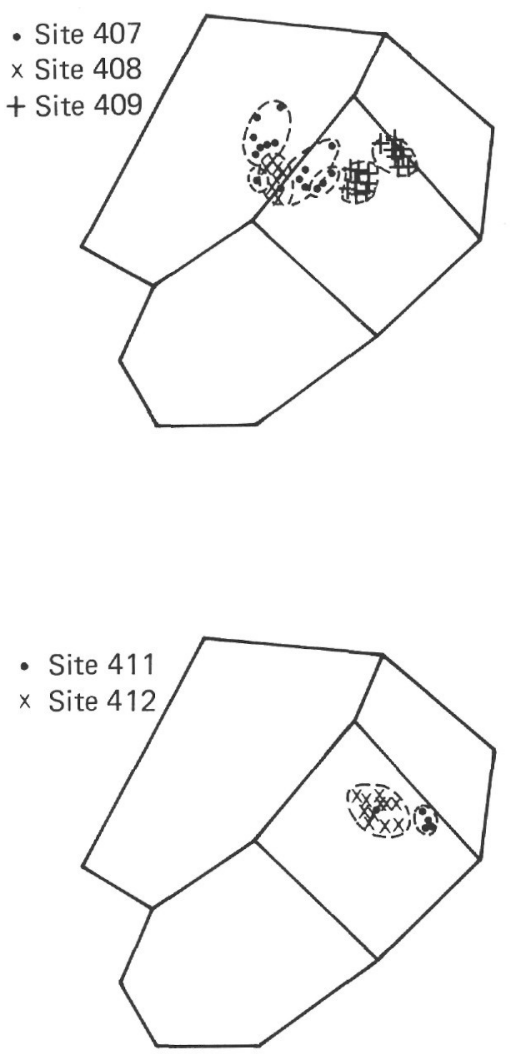

Figure 45. Ti-Zr-Y plots (after Pearce and Cann, 1973) for Leg 49 basalts. Field A, Island arc tholeiites; Field B, Mid-ocean ridge basalts and arc tholeiites; Field C, Calc-alkaline basalts; Field D, "Within-plate" basalts.

Floyd, P.A. and Winchester, J.A., 1975. Magma type and tectonic setting discrimination using immobile elements, Earth Planet. Sci. Lett., v. 27, p. 211-218.

Frey, F.A., Haskin, M.A., Poetz, J.A., and Haskin, L.A., 1968. Rare-earth abundances in some basic rocks, J. Geophys. Res., v. 73, p. $6085-6097$.

Hart, S.R., 1971a. The geochemistry of basaltic rocks. Carnegie Inst. Wash. Yearb. v. 70, p. 353-355.

, $1971 \mathrm{~b} . \mathrm{K}, \mathrm{Rb}, \mathrm{Cs}, \mathrm{Sr}$ and Ba contents and Sr isotope ratios of ocean floor basalts, Phil. Trans. Roy. Soc. London, v. 268A, p. 573-588.

Hart, S.R., Schilling, J.-G., and Powell, J.L., 1973. Basalts from Iceland and along the Reykjanes Ridge: $\mathrm{Sr}$ isotope geochemistry, Nature, v. 246, p. 104-107.

Hart, S.R., Erlank, A.J., and Kable, E.J.D., 1974. Sea floor basalt alteration: Some chemical and $\mathrm{Sr}$ isotopic effects, Contrib. Mineral. Petrol., v. 44, p. 219-230.

Harvey, P.K., Taylor, D.M., Hendry, R.D., Bancroft, F., 1973. An accurate fusion method for the analysis of rocks and chemically related materials by $\mathrm{X}$-ray fluorescence spectrometry, X-ray Spectrom., v. 2, p. 33-44.

Hendry, G.L., 1975. X-ray fluorescence. In Nicol, A.W. (Ed.), Physiochemical methods of mineral analysis: New York and London (Plenum Press), p. 87-152.

Hermes, O.D. and Schilling, J.-G., 1976. Olivine from Reykjanes Ridge and Iceland tholeiites, and its significance to the two-mantle source model, Earth Planet. Sci. Lett., v. 28, p. 345-355.

Huggins, F.E., Virgo, D., and Huckenholz, H.G., 1977. Titanium containing silicate garnets. I. The distribution of $\mathrm{Al}$,
$\mathrm{Fe}^{3}+$ and $\mathrm{Ti}^{4}+$ between octahedral and tetrahedral sites, $\mathrm{Am}$. Mineral., v. 62, p. 475-490.

Kesson, S. and Price, R.S., 1972. The major and trace element chemistry of kaersutite and its bearing on the petrogenesis of alkaline rocks, Contrib. Mineral. Petrol., v. 35, p. 119-124.

Lambert, I.B. and Wyllie, P.J., 1968. Stability of hornblende and a model for the low velocity zone, Nature, v. 219, p. 1240-1241.

Lambert, R. St. J. and Holland, J.G., 1977. Trace elements and petrogenesis of DSDP 37 basalts, Canadian. J. Earth Sci., v. 14 , p. $809-836$.

Langmuir, C.H., Bender, J.F., Bence, A.E., Hanson, G.N. and Taylor, S.R., 1977. Petrogenesis of basalts from the FAMOUS area: Mid-Atlantic Ridge, Earth Planet. Sci. Lett., v.36, p. 133-136.

Langmuir, C.H., Vocke, R.D., and Hanson, G.N., in press. A general mixing equation: applied to the petrogenesis of basalts from Iceland and the Reykjanes Ridge, Earth Planet. Sci. Lett.

Leake, B.E., Hendry, G.L., Kemp, A., Plant, A.G., Harvey, P.K., Wilson, J.R., Coates, J.S., Aucotl, J.W., Lun̈el, T., and Howarth, R.J., 1969. The chemical analysis of rock powders by automatic X-ray fluorescence, Chem. Geol., v. 5, p. 7-86.

Modreski, P.J. and Boettcher, A.L., 1972. The stability of phlogopite + enstatite at high pressures: A model for micas in the interior of the Earth, Am. J. Sci., v. 272, p. 852-869.

Muir, I.D. and Tilley, C.E., 1964. Basalts from the northern part of the rift zone of the Mid-Atlantic Ridge, J. Petrol., v. 5, p. 409-434.

Nisbet, E. and Pearce, J.A., 1973. $\mathrm{TiO}_{2}$ as a possible guide to past oceanic spreading rates, Nature, London, v. 246, p. 468-470. 
O’Nions, R.K., Pankhurst, R.J., and Grö̈vold, K., 1976. Nature and development of basalt magma sources beneath Iceland and the Reykjanes Ridge, J. Petrol., v. 17, p. 315-338.

Pearce, J.A. and Cann, J.R., 1973. Tectonic setting of basic volcanic rocks determined using trace element analyses, Earth Planet. Sci. Lett., v. 19, p. 290-300.

Reynolds, R.C., 1967. Estimation of mass absorption coefficients by Compton scattering: Improvements and extensions of the method, Am. Mineral., v. 52, p. 1493-1502.

Rhodes, J.M., Blanchard, D.P., Rodgers, K.V., Jacobs, J.W. and Brannon, J.C., 1976. Petrology and chemistry of basalts from the Nazca Plate: Part 2 - Major and trace element chemistry. In Hart, S.R., Yeats, R.S., et al., Initial Reports of the Deep Sea Drilling Project, v. 34: Washington (U.S. Government Printing Office), p. 239-244.

Saunders, A.D. and Tarney, J., in press. Geochemistry of basalts from the back-arc spreading centre in the Scotia Sea.

Saunders, A.D., Tarney, J., Stern, C.R., and Dalziel, I.W.D., in press. Geochemistry of Mesozoic marginal basin floor igneous rocks from Southern Chile, Geol. Soc. Am. Bull.

Saunders, A.D., Tarney, J., Weaver, S.D., and Barker, P.F., in press. Scotia Sea Floor: geochemistry of basalts from the Drake Passage and South Sandwich Spreading Centres, Third Symposium on Antarctic Geology and Geophysics, Madison.

Schilling, J.-G., 1973. Iceland mantle plume: geochemical study of Reykjanes Ridge, Nature, v. 242, p. 565-575.

, 1975a. Azores mantle blob: rare-earth evidence, Earth Planet. Sci. Lett. v. 25, p. 103-115.

, 1975b. Rare-earth variations across "normal segments" of the Reykjanes Ridge, $60^{\circ}-53^{\circ} \mathrm{N}$, Mid-Atlantic Ridge, $29^{\circ} \mathrm{S}$, and East Pacific Rise, $2^{\circ}-19^{\circ} \mathrm{S}$, and evidence on the composition of the low-velocity layer, J. Geophys. Res., v. 80 , p. $1459-1473$.

Schilling, J.-G. and Noe-Nygaard, A., 1974. Faroe-Iceland Plume: rare-earth evidence, Earth Planet. Sci. Lett., v. 24, p. 1-14.
Sun, S.-S. and Jahn, B.-M., 1975. Lead and strontium isotopes in post-glacial basalts from Iceland, Nature, London, v. 255, p. 527-530.

Sun, S.-S., Tatsumoto, M., and Schilling, J.-G., 1975. Mantle plume mixing along the Reykjanes Ridge axis: lead isotopic evidence, Science, v. 190, p. 143-147.

Tarney, J., Saunders, A.D., and Weaver, S.D., 1977. Geochemistry of volcanic rocks from the island arcs and marginal basins of the Scotia Sea Region. In Volume 1, Maurice Ewing Series, Island Arcs, Deep Sea Trenches and Back-Arc Basins: Washington (Am. Geophys. Union), p. 367-378.

Thompson, G., Bryan, W.B., Frey, F.A., Dickey, J.S., and Suen, C.J., 1976. Petrology and geochemistry of basalts from DSDP Leg 34, Nazca Plate. In Hart, S.R., Yeats, R.S., et al., Initial Reports of the Deep Sea Drilling Project, v. 34. Washington (U.S. Government Printing Office), p. 215-226.

Walker, D., 1973. Behaviour of X-ray mass absorption coefficients near absorption edges: Reynolds method revisited, Am. Mineral., v. 58, p. 1069-1072.

Weaver, S.D., Sceal, J.S.C., and Gibson, I.L., 1972. Trace element data relevant to the origin of trachytic and pantelleritic lavas in the East African Rift System, Contrib. Mineral. Petrol., v. 36, p. 181-194.

Weaver, S.D., Saunders, A.D., Tarney, J., and Pankhurst, R.J., in preparation. Geochemistry of volcanic rocks from the Bransfield Strait marginal basin.

White, W.G., Schilling, J.-G., and Hart, S.R., 1976. Evidence for the Azores mantle plume from strontium isotope geochemistry of the Central North Atlantic, Nature, London, v. 263, p. 659-663.

Wolery, T.J. and Sleep, N.H., 1976. Hydrothermal circulation and geochemical flux at mid-ocean ridges, J. Geol., v. 84, p. 249-275. 